$1 / 12 / 89$

Draft

\title{
THE PRODUCTIVITY CONSEQUENCES \\ OF \\ WHAT IS LEARNED IN HIGH SCHOOL
}

\author{
John Bishop \\ Cornell University \\ Working Paper \# 88-18
}

Center for Advanced Human Resource Studies

New York State School of Industrial and Labor Relations

Cornell University

Ithaca, New York 14851-0925

607-255-2742

This paper was presented at the Allied Social Sciences Meetings in New York on December 28, 1988. I would like to thank John Gary and George Jakubson for their assistance in creating the extract of the NLS Youth analyzed in this paper. I would also like to express my appreciation to Lauress Wise, Jeffrey McHenry, Miltom Maier, Jim Harris, Jack Hunter and Frank Schmidt for their assistance in locating and interpreting the various studies of job performance in the military. This paper has not undergone formal review or approval of the faculty of the ILR school. It is intended to make results of Center research available to others interested in human resource management in preliminary form to encourage discussion and suggestions. 


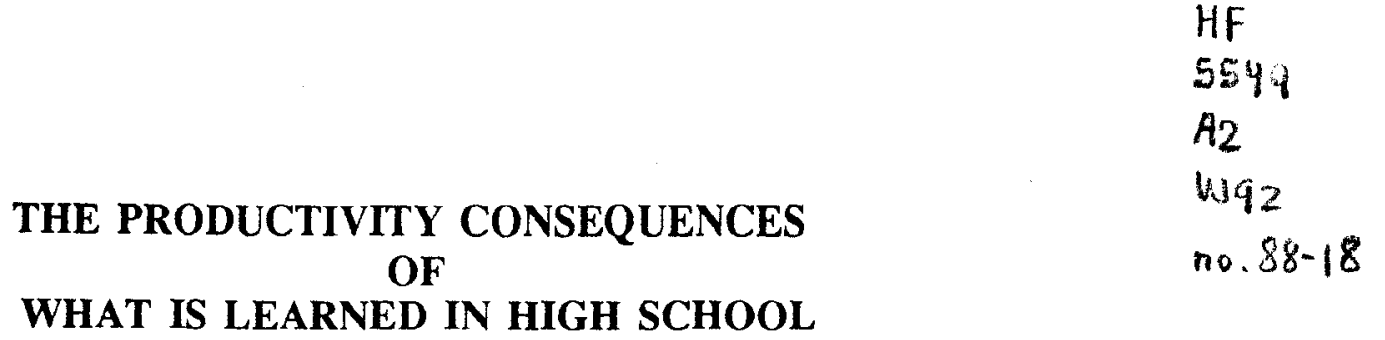

\author{
John H. Bishop \\ Center for Advanced Human Resource Studies \\ New York State School of Industrial and Labor Relations \\ Cornell University \\ Ithaca, New York 14851-0925 \\ 607-255-2742
}

Paper presented at the Allied Social Science Meetings, 2:00PM, December 28, 1988, Hilton Hotel, New York, New York.

\title{
Executive Summary
}

Only 22 percent of American high school graduates take trigonometry, only 30 percent take chemistry, and only 15 percent take physics. The reason for these low enrollment figures is that most high school students see very little connection between how much they learn in math and laboratory science courses and their future success in the labor market. The analysis of NLS data undertaken in this study demonstrates that this perception is correct. During the first 5 years after leaving high school, young men who do not go to college receive no rewards from the labor market for developing competence in science, language arts and mathematical reasoning. For young males, the only academic competency that appears to be rewarded by the labor market is speed in doing simple computations (something that calculators do better than people). The other competency that has major effects on the wages of young men is technical competence (knowledge of mechanical principles, electronics, automobiles and shop tools), something that has been ignored by the reports recommending educational reform.

For the non-college bound female, there is a wage rate benefit to learning advanced mathematics but no wage rate benefits to developing competence in science, language arts or the technical arena. The tendency of American high school students to avoid tough math and science courses and their poor performance on international science and mathematics exams is, therefore, a rational response to market incentives.

Educational reformers are claiming that improved math and science education for the great mass of high school students (not just the 24 percent who report plapss th brajor in 
natural science or engineering) is essential if the workforce is to become more productive. If people who are competent in math and science are more productive workers, why aren't employers paying them commensurately more? Employers fail to reward high school graduates who are competent in math and science because (1) they do not know which of the job applicants who approach them have these competencies and because (2) workers and employers prefer employment contracts in which wage rates adjust only partially to reflect outstanding performance. Consequently, when the specific competencies of students are not signaled to the labor market by a credential, there is little reason to expect the wage rate effects of specific competencies to be the same as their productivity effects.

Consequently, the productivity effects of competence in math and science must be measured directly. This is done by analyzing a series of military data sets in which worker competencies have been correlated with hands-on measures of job performance. This analysis demonstrates that greater competence in science, language arts and higher level math is indeed associated with greater success in training and better performance on the job. These results provide support for the Excellence Commission's claim that major improvements in science and math education for the great mass of high school students will improve the productivity of the work force and contradict Morris Shamos's claim that "widespread scientific literacy is not essential to... prepare people for an increasingly technological society."(Education Week, Nov. 23 1988. p. 28). The results also reinforce the findings regarding the important role of technical competence in blue collar, craft and technician jobs. This is an area of study that needs much more attention than it has been getting.

One of the reasons this may occur is that technical skills may be more visible to employers than academic skills because they are easier to assess informally in the interview. Vocational teachers often help their students get jobs and in the process vouch for their competence. In contrast. most employers have little knowledge of job applicants' competence in math, science and reading. A survey of a stratified random sample of 2000 small and medium sized employers who are members of the National Federation of Independent Business found, for example, that aptitude tests had been given to only 3.2 percent of the new hires at these firms and high school transcripts had been obtained for only 13.7 percent of the new hires who had 12 or fewer years of schooling. As a result, the technical skills measured by the electronics, mechanical comprehension and auto and shop knowledge subtests may be better rewarded in the labor market than competence in math and science. 
The scientific and mathematical competence of American high school students is generally recognized to be very low. The high school graduating class of 1982 took on average of only .43 credits of Algebra II, .31 credits of more advanced mathematics courses, .40 credits of Chemistry and .19 credits of physics (Meyer 1988 Table A.2). The National Assessment of Educational Progress (NAEP) reports that only 7.5 percent of 17 year old students can "integrate specialized scientific information" (NAEP 1988a p.51) and 6.4 percent "demonstrated the capacity to apply mathematical operations in a variety of problem settings." (NAEP 1988b p. 42)

Another way of evaluating American performance in math and science is to make comparisons with the upper secondary students of other nations. In the 1960s, the low ranking of American students in such comparisons was defended by citing the fact that higher proportions of American youth took the international test. This is no longer the case. Figures 1 to 4 plot the scores in Algebra, Biology, Chemistry and Physics against proportion of the 18-year old population in the types of courses to which the international test was administered. Where large proportions of the age cohort took the test, lower mean scores tend to result, but this does not explain the poor performance of American high school seniors. In the Second International Math Study, the universe from which the American sample was drawn consisted of high school seniors taking a college preparatory math course. This group represents 13 percent of the age cohort, a proportion that is roughly comparable to the 12 percent of Japanese youth who were in their sample frame and is considerably smaller than the 19 percent of youth in the Canadian province of Ontario and the 50 percent of Hungarians who took the test. In Algebra, the mean score for this very select group of American students was about equal to the mean score of the much larger group of Hungarians and substantially below the Canadian achievement level (McKnight et al 1987). The median score for the Japanese youth was so high it was surpassed by only 2 or 3 percent of the American students taking the test.

The findings of the Second International Science Study are even more "dismal". Take the comparisons with English-speaking Canada, for example. The $25 \%$ of Canadian 18-year 


\section{ALGEBRA RESULTS FOR 17-YEAR-OLDS}

PERCENT CORAECT

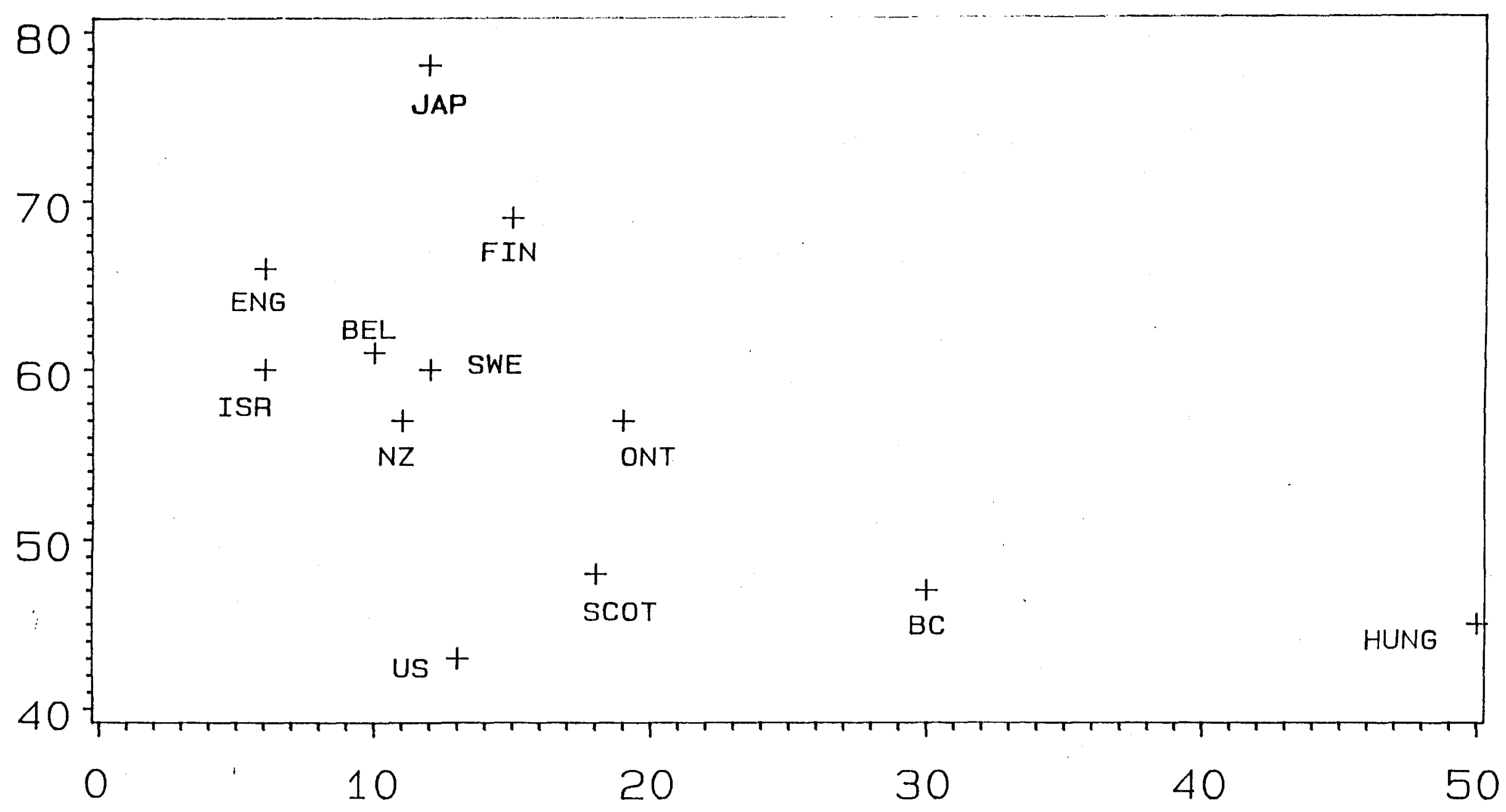




\section{CHEMISTRY RESULTS FOR 18-YEAR-OLDS}

\section{STANDARD DEVIATION UNITS}

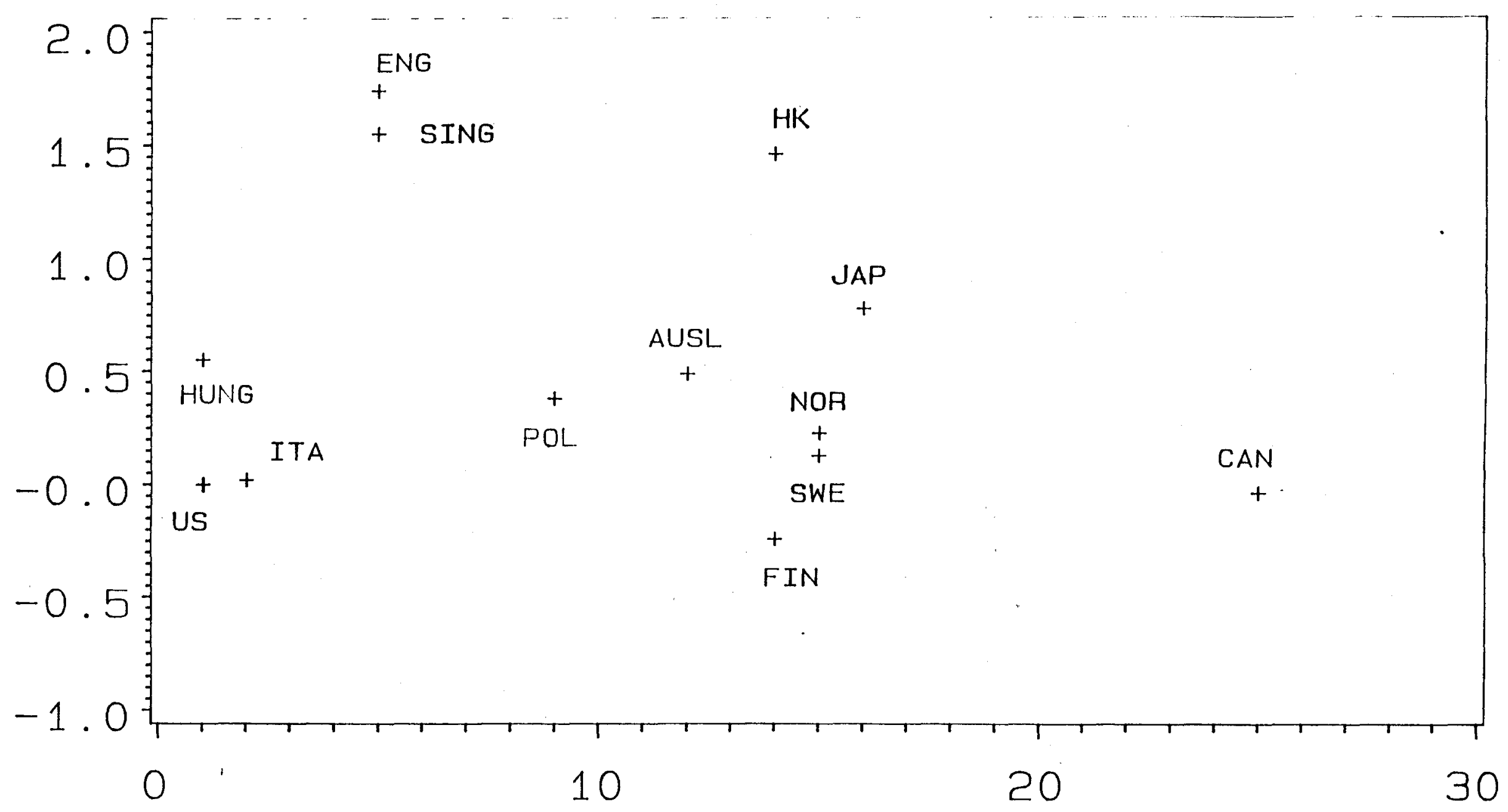




\section{PHYSICS RESULTS FOR 18-YEAR-OLDS}

STANDARD DEVIATION UNITS

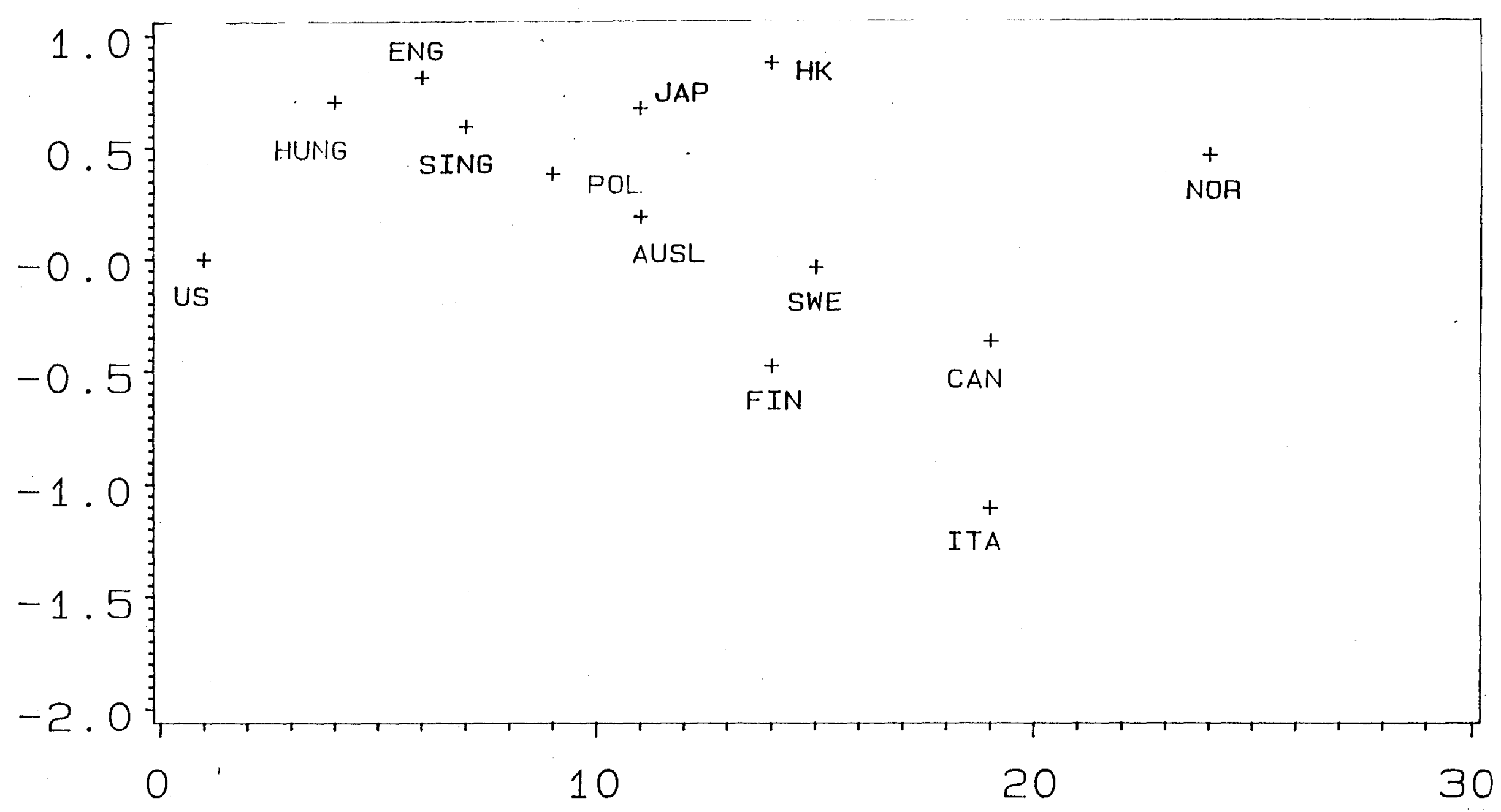


olds taking chemistry know just as much chemistry as the very select $1 \%$ of Americans high school seniors taking their second chemistry course (most of whom are in "Advanced Placement"). The $28 \%$ taking biology know much more than the $6 \%$ of American 17-18 year olds who are taking their second biology course (International Association for the Evaluation of Educational Achievement, 1988).

Clearly, there is a large gap between the science and math competence of young Americans and their counterparts overseas. Will this gap have major consequences for the nation's standard of living? In the view of the National Commission on Excellence in Education, it will:

If only to keep and improve on the slim competitive edge we still retain in world markets, we must dedicate ourselves to the reform of our educational system....Learning is the indispensable investment required for success in the "information age" we are entering. (p. 7).

Behind their call for higher standards and more class time devoted to core academic subjects-math, science, social science and language arts--is an assumption that most jobs require significant competency in these fields. With respect to science, however, there is controversy about these claims. Morris Shamos, an emeritus professor of physics at New York University, argues that "widespread scientific literacy is not essential to... prepare people for an increasingly technological society"(Education Week, Nov. 23 1988. p. 28). The purpose of this paper is to determine whether evidence from the labor market supports these claims?

The first section of the paper addresses the following question: "Are the young workers who have above average competence in these fields receiving higher wage rates?" The findings from this analysis appear on the surface to contradict the recommendations of the Excellence Commission and support Shamos. For young men in the NLS Youth sample, competence in mathematical reasoning, science and language arts does not increase wage rates or eamings in the first 8 years after graduating from high school. The competencies that pay off for young men are speed in doing simple computations (something that calculators do better than people) and technical competence (knowledge of mechanical principles, electronics, automobiles and shop tools), something that has been ignored by the reports recommending educational reform. For young women, the findings are that verbal and mathematical reasoning competence lower unemployment and increase earnings but only mathematical reasoning competence and computational speed increases female wage rates. Competence in 
science has no effect on earnings or wage rates and verbal ability has no effects on wage rates. While these results provide little support for the Excellence Commission's recommendations, they suggest an immediate explanation for the poor performance of American students in science and higher level mathematics. For the 90 percent of the society who are not going to be scientists, engineers, doctors or technicians, there are no immediate labor market rewards for developing these competencies. For the great bulk of students, therefore, the incentives to devote time and energy to the often difficult task of learning these subjects are very weak.

The Excellence Commission's report, however, makes claims about the productivity effects not the wage rate effects of science, mathematics and language arts competency. Are these effects necessarily the same? The second section of the paper addresses this question and concludes that, when the specific competencies of students are not signaled to the labor market by a credential (as is the case for math and science achievement in US high schools), there is very little reason to expect the wage rate effects of specific competencies which are highly correlated with each other to be the same as their productivity effects.

The third section of the paper, therefore, tackles the productivity effects question more directly by analyzing data sets in which worker competencies have been correlated with their relative job performance in specific jobs. These analyses provide support for the Excellence Commission's recommendations for better preparation in math and science, but they also reinforce the findings from the analysis of wage rates, earnings and unemployment regarding the important role of technical competence in blue collar, craft and technician jobs.

\section{WHICH COMPETENCIES ARE REWARDED BY THE LABOR MARKET ?}

The first task of the study is to determine to what degree achievement in the various subjects taught in high school are rewarded by the labor market. This is accomplished by estimating models predicting wage rates, earnings and unemployment as a function of competence in the academic fields of mathematics, science and language arts and in the trade/technical arena while controlling for years of schooling, school attendance, ethnicity, age, work experience, marital status and characteristics of the local labor market. 


\subsection{DATA}

The data set for this analysis is the Youth Cohort of National Longitudinal Survey (NLS)-all eight waves from 1979 to 1986 . The measures of achievement are derived from the Armed Services Vocational Aptitude Battery (ASVAB), a three hour battery of tests used by the armed forces for selecting recruits and assigning them to occupational specialties. The primary purpose of the ASVAB is to predict the success of new recruits in training and their subsequent performance in their occupational specialty. Its ability to accomplish these objectives has been thoroughly researched and the battery has been periodically modified to incorporate the findings of this research. The ASVAB Manual reports:

Extensive research demonstrates that the ASVAB composites used in military selection and classification predict performance in training for a variety of military occupations. (Booth-Kewley, 1983; Maier \& Truss, 1983; Rossmeissl, Martin \& Wing, 1983; Wilbourn, Valentine, \& Ree, 1984). For example, validity coefficients for electrical \& mechanical equipment repair specialties range from .36 to .74 ; those for communication specialties range from .36 to .52 ; those for data processing specialties range from .39 to, 77 ; and those for clerical and supply specialties range from .53 to .73 . These coefficients have been corrected for restriction of range. (US Military Entrance Processing Command, 1984 , p. 18)

Eighty percent of the jobs held by enlisted personnel in the military have civilian counterparts so the research on the validity of the ASVAB in military settings generalizes quite well to major segments of the civilian economy (US Department of Defense, 1984). The test is highly correlated with the cognitive subtests of the General Aptitude Test Battery, a personnel selection test battery used by the US Employment Service, the validity of which has been established by studies of over 500 occupations. A validity generalization study funded by the armed forces concluded "that ASVAB is a highly valid predictor of performance in civilian occupations" (Hunter Crossen and Friedman, 1985, p. ix).

During the summer of 1980 all members of the NLS Youth sample were asked to take this test and offered a $\$ 50$ honorarium as an inducement. The tests were successfully administered to 94 percent of the sample. Testing was generally conducted in groups of 5 to 10 persons. The 1980 version of the ASVAB (Form 8A) was administered by staff of the National Opinion Research Corporation according to strict guidelines conforming to standard ASVAB procedures. The Department of Defense which funded this project had Dr. 
R. D. Bock an authority on educational and psychological testing evaluate the quality of the resulting ASVAB data. He concluded:

Data from responses of [the NLS Youth Sample] to the ASVAB are free from major defects such as high levels of guessing or carelessness, inappropriate levels of difficulty, cultural test-question bias, and inconsistencies in test administration procedures. (quoted in US Military Entrance Processing Command, 1984, p. 19)

The ASVAB test battery is made up of 10 subtests: Mechanical Comprehension, Auto and Shop Knowledge, Electronics Knowledge, Clerical Checking (Coding Speed), Numerical Operations (a speeded test of simple arithmetic), Arithmetic Reasoning, Mathematics Knowledge (covering the high school math curriculum), General Science, Word Knowledge and Paragraph Comprehension. A fuller description of each of these subtests together with sample questions is given in Appendix B.

Two dimensions of mathematical achievement are measured: the speed of doing simple mathematical computations is measured by a three minute 50 problem arithmetic computation subtest which will be referred to as computational speed. Mathematical reasoning ability is measured by a composite of the mathematics knowledge and arithmetic reasoning subtests. Science achievement is indexed by the ASVAB's General Science subtest. This test focuses on science definitions and has minimal coverage of higher level scientific reasoning. Verbal achievement is measured by a composite made up of the word knowledge and paragraph comprehension subtests.

The universe of skills and knowledge sampled by the mechanical comprehension, auto and shop information and electronics subtests of the ASVAB roughly corresponds to the vocational fields of trades and industry and technical so these subtests are aggregated into a single composite which is interpreted as an indicator of competence in the "technical" arena. ${ }^{3}$

Competencies that are unique to clerical and retail sales jobs do not appear to be measured by the ASVAB. The ASVAB does contain a seven minute 84 item clerical checking subtest which was intended to predict performance in clerical jobs but validity studies of clerical jobs in the military have found that it does not add to the validity of composites based on verbal, arithmetic reasoning and mathematics knowledge subtests (Wise, McHenry, Rossmeissl and Oppler, 1987). The clerical checking subtest is included in the analysis but it should not be viewed as a valid predictor of clerical competency. These six 
test composites have all been normalized to have zero mean and unit variance. The alternate form reliabilities of these composites are approximately .92-.93 for Technical, .93 for Math, 93-.94 for Verbal, .80 for General Science, .72 for Numerical Operations and .77 for Clerical Checking (US Military Entrance Processing Command 1984; Palmer et al, 1988). All of these competencies are highly correlated with years of schooling. When these composites are regressed on age, ethnicity, proportion of 1980 spent in school, region, work experience, occupation of parents and schooling, the coefficients on years of high school range between .19 for math and .28 for verbal for males and range from .12 for technical and .24 for verbal and clerical speed for females. Greater work experience significantly increased the clerical speed of women but did not have positive effects on any of the other competencies.

Four measures of labor market success are being studied: the log of the hourly wage rate in the current or most recent job, the log of calendar year earnings if they exceed $\$ 500$, earnings in dollars (with nonworkers over age 16 included in the sample) and the share of labor force time that the individual was unemployed (defined only for people who were in the labor force for at least 8 weeks during the calendar year).

An extensive set of controls are included in the estimating equations. Reports of weeks spent in employment are available all the way back through 1975 . For each individual, these weeks worked reports were aggregated across time and an estimate of cumulated work experience $\left(\mathrm{EXP}_{\mathrm{it}}\right)$ was derived for January 1 of each year in the longitudinal file. This variable and its square is included in every model as is age and its square. School attendance is controlled by four separate variables. The first variable indicates whether the youth is in school at the time of the interview. The second is a dummy variable indicating whether the youth has been in school since the last interview. The third is a dummy variable indicating whether the student is attending school part time. A positive coefficient is expected on this variable when the other controls for school attendance are entered in the model. The fourth variable is a measure of the share of the calendar year that the youth reported attending school derived from the NLS's monthly time log. Years of schooling is also controlled for by four variables: years of schooling, a dummy for high school graduation, years of college education completed, and years of schooling completed since the ASVAB tests were taken.

The individual's family situation is controlled by dummy variables for being married and for having at least one child. Minority status is controlled by a dummy variable for Hispanic and 
two dummy variables for race. Characteristics of the local labor market were held constant by entering the following variables: dummy variables for the four Census regions, a dummy variable for rural residence and for residence outside an SMSA and measures of the unemployment rate in the local labor market during that year.

\subsection{HYPOTHESES, MODEL SPECIFICATION AND RESULTS}

The labor market consequences of the competencies that a young person develops early in life will be examined by testing seven hypotheses relating to the impact of ASVAB subtest scores on wages, earnings and unemployment. These hypotheses are first specified and then the relevant statistical evidence is reviewed.

\section{Main Effects of Test Scores}

Hyp. 1: Subtests measuring academic competencies do not have significant positive effects on wage rates and earnings in the years immediately following high school graduation.

The reason for expecting the academic subtests to have modest effects on labor market success is that analyses of other data sets such as High School and Beyond and NLS Class of 1972 have typically found that academic achievement test scores have small effects on early labor market success (Taubman and Wales 1975; Hauser and Daymont 1977; Gardner 1982; Meyer 1982; Kang and Bishop 1986).

Hyp 2:Subtests measuring generic technical knowledge have positive effects on wage rates and earnings and negative effects on unemployment of young men.

The primary reason for expecting tests of generic technical knowledge to have positive effects on labor market success of young men is the demonstrated positive effect of trade and technical course taking on labor market success when the student obtains a job which uses the skills learned in school (Bishop 1988). Since technical skills appear to payoff only when used, the returns to technical skills are likely to be gender specific. Very few young women 
have jobs for which knowledge of electronics, mechanical principles, auto mechanics and shop tools are essential, so the technical composite is not likely to be good predictor of wages and earnings for women. Very few young men work in clerical jobs, so the clerical checking subtest is not likely to be a useful predictor of wages and earnings for men. These hypotheses are first tested in a model in which the technical and academic competencies are assumed to have linear and additive effects on labor market outcomes:

(1) $\underline{Y}_{t}=\underline{a}_{t} A+b_{t} C+c_{t} T+e_{t} S+g \underline{Z}_{t}+\underline{u}_{t}$ for $t=1979 \ldots 1986$

where $\underline{Y}_{t} \quad$ is a vector of labor market outcomes (wage rates, earnings and unemployment) for year $\mathrm{t}$.

$\underline{A}$ is a vector of test scores measuring competence in mathematical reasoning, reading and vocabulary and science knowledge.

$\mathrm{C}$ is a measure of speed in simple arithmetic computation.

$\mathrm{T}$ is he technical composite measuring mechanical comprehension and electronics, auto and shop knowledge.

$S$ is clerical checking speed.

$\underline{Z}_{1}$ is a vector of control variables such as age, work experience, schooling, school attendance, marital status, parenthood, minority status, region, residence in an SMSA and local unemployment rate.

$\underline{u}_{t}$ is a vector of disturbance terms for each year.

Young men: The results of estimating model 1 are presented in Table 1 through Table 4. Complete results for sample runs are available in Appendix A. The results for young men are as predicted--high level academic competencies do not have positive effects on wage rates and earnings. The mathematics reasoning, verbal and science composites all have negative effects on wage rates and earnings and often positive effects on unemployment. In the wage rate models, 23 of 24 coefficients were negative. $F$ tests on the sum of the coefficients on the three academic composites are presented in columns 9-11 of tables 1 through 4 . The sum of the three coefficients in the wage rate models was significantly (at the 5 percent level) negative in 5 of the 8 years. In the log earnings models, 20 of 21 coefficients were negative. In the dollar earnings models, 19 of 21 coefficients were negative. $F$ tests on the sum of the 
coefficients on academic tests in the dollar earnings models find they are significantly negative in 5 of the 7 years. In the unemployment models, about half of the coefficients were positive and the $F$ test on the sum of the coefficients was never significantly different from zero at even the 10 percent level.

Speed in arithmetic computation has substantial positive effects on labor market success of young men. A one standard deviation increase in computational speed increased wage rates by 5.3 percent and earnings by $\$ 837$ (10.4 percent) on average. The wage and earnings effects grew over time. The unemployment effects, in contrast, diminished with time. They were significant in 1979-80 but not later. In all eight of the years studied, computational speed had a significantly larger impact on wage rates and earnings than the aggregated academic tests. Computational speed, however, is something that calculators do better than people and is not viewed by most educators as an appropriate goal for a high school mathematics curriculum (National Council of Teachers of Mathematics 198_).

Being able to do clerical checking rapidly significantly lowered unemployment in 4 of the 7 years, significantly increased dollar earnings in 6 of 7 years but had no effect on wage rates.

Technical competence had large and significant positive effects on wage rates and earnings and negative effects on unemployment. The $F$ tests indicate that in all eight years analyzed, it had significantly more positive effects on wage rates and earnings than the aggregated academic tests. A one standard deviation increase in the technical composite increased wage rates by 5.6 percent and yearly earnings by $\$ 1065$ (12.5 percent) and reduced the rate of unemployment by 1.9 percentage points. This is a very substantial return to technical achievement.

Young women: The competencies that pay off for women are different from the competencies that payoff for men. As with men, scientific competence has no effect on their wage rates, earnings or unemployment. Unlike men, however, technical competence does not pay off. In fact, technical competence had a significant tendency to increase unemployment from 1979 through 1983. As with men, speed of arithmetic computation significantly raised wage rates and earnings. A one SD increase in computational speed increased wage rates by 3.2 percent and earnings by $\$ 311$ (6.4 percent) on average. Unlike men, mathematical reasoning capability had a significant impact on wage rates, earnings and unemployment. A 
one SD increase in mathematical reasoning competency raised the wage rates of young women by 2.5 percent and earnings by $\$ 407$ (4.4 percent) and decreased unemployment by 1.0 percentage point. The wage and earnings effects appear to have grown with time.

Still another contrast with men is the large effects of verbal competence on the unemployment and earnings of young women. A one SD improvement in verbal achievement lowered the risk of unemployment by 2.3 percentage points and raised earnings by $\$ 229$ (6.2 percent). Wage rate effects were much smaller. Verbal competence had a significant effect on a women's wage rate only in 1985 and 1986.

The overall effect of the three academic competencies on unemployment and earnings was quite substantial. A one SD increase in all three tests lowered the risk of unemployment by 3.6 percentage points and raised earnings by $\$ 594$ ( 8.1 percent). The impact of the academic tests on wage rates was much smaller--3.3 percent on average--though it appears to be growing over time.

The clerical checking subtest had weak positive effects on wage rates of young women and large significant effects on their earnings and unemployment.

\section{Interaction Effects}

The rest of the hypotheses to be tested relate to how the payoff to academic and technical competencies and speed in arithmetic computation varies with further education, student status and age. To test these hypotheses, a composite of the academic subtests (TA) with unit variance was defined and this composite, the technical composite and the computational speed subtest were then interacted with age deviated from 22 , with years of college and with student status. In order to maximize the power of these tests it was assumed that the main effects of the test compesites and all interactions with these composites were the same in all years.

$$
\text { (2) } \underline{Y}_{t}=\underline{\mathrm{aA}}+\mathrm{bC}+\mathrm{cT}+\mathrm{dTA}+\mathrm{e}_{s}+\mathrm{g} \underline{Z}_{t}+\underline{u}_{t} \quad t=1981, \ldots 1986
$$

where $b=b_{0}+b_{1}\left(\right.$ Age $\left._{1}-22\right)+b_{2}($ Student $)$

$$
\begin{aligned}
& c=c_{0}+c_{1}\left(\text { Age }_{t}-22\right)+c_{2}\left(\text { Student }_{4}\right) \\
& d=d_{1}\left(\text { Age }_{\mathrm{t}}-22\right)+d_{2}\left(\text { Student }_{4}\right)+d_{3}\left(\text { Yrs of College } e_{t}\right)
\end{aligned}
$$


Student $t_{1}$ proportion of the calendar year $\mathrm{t}$ attending school

The models were estimated using seemingly unrelated regression. This analysis is conducted on a reduced sample of young people who were valid observations in the model in all of the years between 1981 and 1986. When interactions are defined in this way, the main effects coefficients on the six composites ( $\underline{a}, b_{0}$ and $c_{0}$ ) provide estimates for year $t$ of the effect of the competency on labor market outcomes of 22 year old high school graduates who are not attending school. These subtest main effects coefficients are reported in the top panel of Table 5. The coefficients on the interaction of age and the test composites $\left(b_{1}, c_{1}\right.$ and $\left.d_{1}\right)$ provide estimates of the effect of age on the payoff to academic and technical competencies while controlling on years of college and student status.

\section{Age and the Payoff to Academic Competency}

Hyp 3: The return to academic competency grows with the age of the worker.

$$
\mathrm{d}_{1}>0 \text {. }
$$

A number of studies have found that the return to overall academic achievement increases with the age of the worker (Hauser and Daymont 1977; Taubman and Wales 1975). This would occur if academic achievement improves access to jobs offering considerable training and enables the worker to get more out of the training. A second possible cause of a positive age interaction is that academic achievement is poorly signaled to employers so there are long delays before the labor market identifies and rewards workers who because of their academic achievements are exceptionally productive workers.

The findings regarding the effect of age on the payoff to academic competency are presented in row 8 of Table 5. They do not support hypothesis 3. None of the age/academic composite interaction coefficients in the wage and earnings regressions come even close to being significantly positive and one is significantly negative. The statistically significant interaction coefficient in the male unemployment regression suggests that academic competency has its most favorable effect on unemployment immeadiately after graduating from high school.

The competency that interacts positively with age is computational speed. Interactions of age and computational speed are statistically significant in the male wage rate and dollar 
earnings regressions and both of the female earnings equation. Ceteris paribus, a one standard deviation differential in computational speed raises the wage rates of male high school graduates not in school by 4.5 percent at age 19,6.2 percent at age 22 and 7.9 percent at age 25. The impact of one SD of computational speed on the earnings of young men was $\$ 623$ at age $19, \$ 1088$ at age 22 and $\$ 1553$ at age 25 . In the female earnings models, one SD of computational speed raises earnings by $\$ 157$ at age 19 , by $\$ 442$ at age 22 and by $\$ 727$ at age 25. The interaction coefficients are positive but not statistically significant in the models of female wage rates and male log earnings. ${ }^{2}$

The positive coefficients on the age interaction in the unemployment regressions for both men and women imply that immeadiately after leaving school, the payoff to computational speed arises largely from its impact on unemployment. This effect diminishes over time but the wage rate and earnings effects (which were initially rather small) become larger and larger.

\section{Age and the Payoff to Technical Competence}

Hyp 4: Holding calendar year constant, the effect of technical competency test scores on labor market success should be smaller for older workers. $c_{1}<0$.

The reason for expecting the effect of technical competency tests to diminish as a worker ages is that previous studies have found that the large initial effects of trade and technical courses on wages and earnings diminish as the worker gets older (Meyer 1982; Kang and Bishop 1986). This is what one would expect if vocational courses serve as a signal of occupational competency but the signal has diminishing value as the individual gains post-school work experience. Meyer proposes an alternative explanation. He suggests that new hires who already have training in the occupation have less to learn so their performance and wages improve at a slower rate than the new hires who had no previous relevant training or experience. When, however, skill is defined by a technical competency test rather than by vocational courses taken, these explanations may not hold. When filling jobs that involve a great deal of on-the-job training, employers may give preference to job seekers who are already partially trained and who have demonstrated their ability to learn the skills required. 
If this is the way employers behave, initial skill advantages may be magnified by a positive correlation with opportunities for further training on-the-job and initial rewards for technical competency might grow with age.

None of the coefficients on interactions of technical competence with age have the significantly negative sign predicted by hypothesis 4 , so the hypothesis is rejected. In fact in the wage rate model for young men, the interaction between age and technical competence is significantly positive. The interpretation we give these results is that even though the value of the "vocational graduate" signal may diminish with time, the value of technical knowledge does not diminish in value with time out of high school. In fact, for men the value grows either because a wider circle of employers become aware of it or because the individual is able to get jobs which offer more intensive training.

\section{Effect of School Attendance on the Payoff to Academic and Technical Competencies}

Hyp 5: The wage rate effects of academic, technical and computational speed competencies are less positive for students than for those who have completed their schooling. $b_{2}<0, c_{2}<0$ and $d_{2}<0$ in the wage regression.

Students working during the summer or part time during the school year generally have a narrower choice of occupations than young people who have completed their schooling. The high turnover rates and the necessity of scheduling work around school pushes students into occupations which may not give scope to the academic and technical competencies measured by the ASVAB.

Hyp 6: Among students, high academic competencies are associated with lower earnings. $d_{2}<0$ in the earnings regressions.

Young people with strong academic competency are typically faster learners than their peers and are consequently more likely to devote 100 percent of their time to study (eg. attend a selective college where students do a great deal of home work). Studies analyzing which students tend to devote the most time to jobs for pay have found that students with low 
grades and academic test scores tend to work more than their peers who are doing better in school (Hotchkiss, Bishop and Gardner 1982).

The findings are presented in rows $10-12$ of Table 5. In the wage rate regression, 5 of the 6 coefficients on interactions between student status and test composites had negative coefficients but none of these coefficients were statistically significant. This result suggests that while the opportunities for employment open to students are generally less attractive, we cannot reject the hypothesis that wage rates and unemployment are just as contingent on the competencies of students as they are for nonstudents. On the other hand, being a student has strong negative effects on the earnings payoff to academic competency. Holding the other test composites constant, a one standard deviation increase in math, verbal and science competencies lowered the earnings of 22 year old male nonstudents by $\$ 590$ and lowered the earnings of 22 year old male students by $\$ 1686$. For females the effect of a one SD increase in these competencies was an earnings increase of $\$ 967$ for nonstudents and a $\$ 1289$ decrease in earnings for students. Students with high academic test scores appear to choose to spend less time working in the labor market than students with low academic test scores.

\section{The Effect of College Education on the Payoff to Academic Competencies}

Academic skills appear to be more critical to job performance in professional and managerial occupations than in blue collar and clerical occupations. This suggests the following hypothesis:

Hyp 7: The return to academic competency is larger for college graduates than for high school graduates in the log wage rate and log earnings models. $d_{3}>0$.

Analyses of the NBER/Thorndike data on men who were in the Air Force during World War II, supports this hypothesis but analyses of other data sets have been more equivocal (Taubman and Wales 1975; Hause 1975; Willis and Rosen 1979).

For young women, the hypothesis that the payoff to academic competency is greater for college graduates appears to be supported by the data. Academic competency has a bigger effect on the wage rates and earnings of young women with a college education than it has on the wages and earnings of women with a high school education. On the other hand, high 
test scores appear to have a smaller impact on the unemployment of college graduates than on the unemployment of high school graduates. This result appears to be caused by ceiling effects in the linear specification of the unemployment risk model for the main effects of test scores and schooling appear to be quite substantial.

The results are more mixed for males. The dollar earnings payoff to higher academic test scores was significantly lower for college graduates than for high school graduates. The wage rate payoff for academic competency was higher for college graduates but not significantly so.

\section{The Effect of Dropping the Years of Schooling Signal from the Model}

Since schooling and academic competencies are highly correlated and academic competencies are difficult to measure, employers often use years of schooling as a signal for academic competencies. This suggests that academic competency will have larger effects on wages and earnings when years of schooling are not included in the model. To test this signaling hypothesis, model 2 was reestimated with the same cross equation constraints as before but without the three measures of schooling at the time the ASVAB test was taken-years of schooling, years of college and a high school graduate dummy. The only education variable that remained in the model was years of schooling completed after 1981 which was designed to capture the effects of changes in school generated competencies after taking the ASVAB test. The results of this estimation are presented in Table 6. The effect of dropping the education variables from the model can be determined by comparing these results to those presented in Table 5. The coefficients on technical competency do not become more positive, so it appears that years of schooling is not serving as a signal for technical competency. The coefficients on clerical speed and computational speed rise modestly. The coefficients on the academic composites become substantially more positive. For women, the wage rate effect of a one SD increase in math reasoning, verbal and science competencies increases from 1.9 percent in Table 5 to 5.4 percent in Table 6. Effects on log earnings increase from 8.8 percent to 14.2 percent. For men, the wage rate effect of a one SD increase in the three high school academic competencies changes from -2.4 percent in Table 5 to -0.4 percent in Table 6 and the response of earnings changes from -3.9 percent to 0.8 percent. For males these improvements in the effect of academic competencies only turn negative effects into zero 
effects. It would appear that the Excellence Commission is recommending that young males pursue a line of study that does not in fact raise their wages and earnings in the short and intermediate term.

\section{DOES THEORY IMPLY THAT THE WAGE EFFECTS OF SPECIFIC COMPETENCIES ARE GOOD ESTIMATES OF THE PRODUCTIVITY EFFECTS OF THESE COMPETENCIES ?}

Achievement in science has no effects on wage rates, earnings or unemployment of young men and women. Achievement in mathematical reasoning has no effect on the wage rates and earnings of young men. Verbal competency has no effect on the wage rates on young men and women and no effect on the earnings of young men. The finding of small or negative effects of academic competencies for young adults is not unique to this data set. Similar results were obtained in Willis and Rosen's (1979) analysis of the earnings of those who chose not to attend college in the NBER-Thorndike data, Kang and Bishop's (1986) analysis of High School and Beyond seniors and Bishop, Blakemore and Low's (1985) analysis of both Class of 1972 and High School and Beyond data. ${ }^{3}$ These results suggest an immediate explanation for the poor performance of American students in science and higher level mathematics. For the 90 percent of the society who are not planning to pursue a career in medicine, science or engineering, there are no immediate labor market rewards for developing these competencies. For the great bulk of students, therefore, the incentives to devote time and energy to the often difficult task of learning these subjects are very weak.

Do these findings also imply that if a way could be found to recruit a high quality engineering and scientific elite (possibly by recruiting talented scientists and engineers from abroad or early identification of scientifically talented youth), there would be little need to worry about the poor math and science preparation of most American youth. In other words, are the productivity effects of these achievements essentially zero in the types of jobs occupied by most young workers? Speed in simple arithmetic computations has large effects on the wage rates of both sexes. Technical competence has large effects on wage rates of young men. Do these skills have comparable effects on productivity? It will be demonstrated shortly that the answer to these questions is NOT NECESSARILY. 
In the United States academic achievements in high school-- particularly the fine details of achievement in a particular domain like science, mathematical reasoning or reading ability-are not well signaled to the labor market. In a world in which academic abilities are poorly signaled, productivity is hard to measure, specific human capital is important, employers need to promote cooperation among their employees and workers are risk averse, the wage rate effects of tests measuring various dimensions of academic achievement are not reliable indicators of productivity effects of these achievements. When competencies which are highly correlated with each other are poorly signaled to the labor market, employers have a difficult time figuring out which competencies they need and a even more difficult time finding high school graduates with the particular constellations of academic abilities they may believe they need. A conditional expectation function predicting productivity on the basis of the very imperfect signals available to American employers is unlikely to replicate the conditional expectation of true productivity as a function of the true values of the competencies.

\section{The Signaling Failure}

In Canada, Australia, Japan, and Europe, the educational system administers achievement exams which are closely tied to the secondary school curriculum. Students generally take between 3 and 9 different examinations. These are not pass/fail minimum competency exams. On the Baccalaureat, for example, there are four different levels of pass: Tre's Bien, Bien, Assez Bien and a regular pass. Failure rates are often quite high (Noah and Eckstein 1988). Not only is university admission based on these tests but job applications, at all levels, require information about exam grades as well. Good grades on the toughest exams--physics, chemistry, advanced mathematics--carry particular weight with employers.

In Japan, clerical, service and blue collar jobs at the best firms are available only to those who are recommended by their high school. The most prestigious firms have long term arrangements with particular high schools to which they delegate the responsibility of selecting the new hire(s) for the firm. The criteria by which the high school is to make its selection is, by mutual agreement, grades and exam results. In addition, most employers administer their own battery of selection tests prior to hiring. The number of graduates that a high school is able to place in this way depends on its reputation and the company's past 
experience with graduates from the school. Schools know that they must be forthright in their recommendations because if they fail just once to make an honest recommendation, the relationship will be lost and their students will no longer be able to get jobs at that firm (Rosenbaum and Kariya 1987).

The hiring environment for clerical, service and blue collar jobs is very different in the US. American employers generally lack objective information on applicant accomplishments, skills, and productivity. Tests are available for measuring competency in reading, writing, mathematics, science, and problem solving, but EEOC guidelines resulted in a drastic reduction in their use after 1971. These guidelines prohibit the use of a test on which minorities or women score below white males unless the employer can prove that the test is a valid predictor of performance on jobs at that firm. Each firm proposing to use a test had to do its own validity study separately on blacks and whites (29C.F.R.S607.5(b); Wigdor, 1982). Small firms found the costs prohibitive and did not have enough employees to do such a study. The firm also had to be able to prove that no other test or selection method was available that was equally valid but had less adverse impact. Since there are hundreds of potential selection methods with less adverse impact, the firm was potentially obligated to prove that all of these alternatives were less valid predictors of job performance than the one selected. A company which has its testing program struck down must potentially pay 5 or 10 years of back wages to every job applicant from a minority group who was not hired. Many companies receive nearly a hundred applications for every job they fill so the potential liability is enormous. Not surprisingly companies are extremely cautious about using tests. The threat of EEO suit caused many firms to drop tests altogether, while other firms used the test only to screen out the bottom 10 or 20 percent of job applicants, rather than to select those with the highest scores (Friedman and Williams, 1982).

A 1987 survey of a stratified random sample of small-and medium-sized employers who were members of the National Federation of Independent Business found that aptitude test scores had been obtained in only $3.15 \%$ of the hiring decisions studied (Bishop and Griffin, forthcoming).

Other potential sources of information on effort and achievement in high school are transcripts and referrals from teachers who know the applicant. Both are under-used. In the NFIB survey, transcripts had been obtained prior to the selection decision for only $13.7 \%$ of 
the hires of people with 12 or fewer years of schooling. If a student or graduate has given written permission for a transcript to be sent to an employer, the Buckley amendment obligates the school to respond. Many high schools are not, however, responding to such requests. The experience of Nationwide Insurance, headquartered in Columbus Ohio, is probably representative. The company obtains permission to get high school records from all young people who interview for a job. It sent over 1,200 signed requests to high schools in 1982 and received only 93 responses. The company reported that colleges were more responsive. Most high schools have apparently designed their systems for responding to requests for transcripts around the needs of college-bound students rather than the students who seek jobs immediately after graduating.

There is an additional barrier to the use of high school transcripts in selecting new employees--when high schools do respond, it takes a great deal of time. For Nationwide Insurance the response almost invariably took more than 2 weeks. Given this time lag, if employers required transcripts prior to making hiring selections, a job offer could not be made for at least a month. Most jobs are filled much more rapidly than that.

Only 16 percent of the NFIB employers asked the applicants with 12 or fewer years of schooling to report their grade point average. The lack of application questions about school performance does not reflect an employer belief that school performance is a poor predicator of job performance. When employers have information on grade point averages, it has a major effect on the ratings employers assign to job applicants in policy capturing experiments (Hollenbeck and Smith, 1984). The absence of questions about grades from most job applications probably reflects the low reliability of self reported data, the difficulties of verifying it, and the fear of EEO challenges to such questions. Hiring on the basis of recommendations by high school teachers is also uncommon. In the NFIB survey, when someone with 12 or fewer years of schooling was hired, the new hire had been referred or recommended by vocational teachers only in $5.5 \%$ of the cases and referred by someone else in the high school in only $3.1 \%$.

The only information about school experiences requested by most employers is years of schooling, diplomas and certificates obtained. and area of specialization. Hiring decisions are based on easily observable characteristics which are imperfect signals of the competencies the employer cannot observe directly. As a result, hiring selections and starting wage rates 
are often not influenced by even very gross indicators of academic achievement such as GPA, AFQT or SAT scores (Bishop 1987b). Given the limited information available to employers prior to hiring, it is not realistic to expect their decisions to reflect in a refined manner the specific combinations of academic competencies that students bring to the market.

\section{Implicit Contracts and Performance Rewards}

After a worker has been at a firm a while, the employer presumably learns more about the individual's capabilities and is able to observe performance on the job. Workers assigned to the same job often produce very different levels of output (Hunter, Schmidt and Judiesch 1988). Why, one might ask, are the most productive workers (those with just the right mix of specific competencies) not given large wage increases reflecting their higher productivity? The reason appears to be that workers and employers prefer employment contracts which offer only modest adjustments of relative wages in response to perceived differences in relative productivity. There are a number of good reasons for this preference: the unreliability of the feasible measures of individual productivity (Hashimoto and $\mathrm{Yu}, 1980$ ), risk aversion on the part of workers (Stiglitz, 1974), productivity differentials that are specific to the firm (Bishop, 1987a), the desire to encourage cooperation among coworkers (Lazear 1986) and union preferences for pay structures which limit the power of supervisors. In addition, compensation for differences in job performance may be non-pecuniary -- praise from one's supervisor, more relaxed supervision, or a high rank in the firm's social hierarchy ( $R$. Frank, 1984).

A study of how individual wage rates varied with initial job performance found that when people hired for the same or very similar jobs are compared, someone who is $20 \%$ more productive than average is typically paid only $1.6 \%$ more. After a year at a firm, better producers received only a $4 \%$ higher wage at nonunion firms with about 20 employees, and they had no wage advantage at unionized establishments with more than 100 employees or at nonunion establishments with more than 400 employees (Bishop, 1987a).

If relative wage rates only partially compensate the most capable workers in a job for their greater productivity, why don't they obtain promotions or switch to better paying firms? To some degree they do, particularly in managerial and professional occupations. This explains why workers who score high on tests and/or get good grades are less likely to be unemployed and more likely to be promoted, and why, many years after graduation, they 
eventually obtain higher wage rates (Wise 1975; Bishop 1988b). Since, however, worker productivity cannot be measured accurately and cannot be signaled reliably to other employers, this sorting process is slow and only partially effective. Consequently, when men and women under the age of 30 are studied, the wage rate effects of specific competencies may not correspond to their true effects on productivity and, therefore, direct evidence on productivity effects of specific competencies is required before conclusions may be drawn. We turn now to an examination of direct evidence on the effects of academic and technical competencies on the job performance of young men.

\section{THE IMPACT OF ACADEMIC AND TECHNICAL COMPETENCIES ON THE JOB PERFORMANCE OF YOUNG MEN}

This section of the paper puts the theoretical arguments of the previous section to an empirical test. A direct estimate of the relative importance of different competencies is undertaken by estimating models in which measures of job performance are regressed on all 9 subtest scores of the ASVAB battery. These direct measures of the productivity effects of the competencies measured by the ASVAB, will then be compared to the wage and earnings regressions of section 1. Is technical competence an important determinant of job performance as well as wages? Do verbal skills and scientific competencies which have no effects on wage rates, nevertheless, have significant positive effects on job performance? The wages and earnings of young men were influenced by computational speed not mathematical reasoning ability. Is this the case for job performance as well?

The ASVAB is one of the most thoroughly researched selection and classification batteries in existence, so there is a wealth of evidence on how its subtests effect job performance in a great variety of jobs. The test battery was developed by the armed forces for use within the military, so military recruits have been the subject of almost all of this research. Eighty percent of the jobs held by enlisted personnel in the military have civilian counterparts, so the research on the validity of the ASVAB in military settings generalizes quite well to large portions of the civilian sector (US Department of Defense, 1984). The civilian occupations that are not represented in the ASVAB research are professional, manager, farmer, sales representative, and sales clerk. Since most of the soldiers studied were young and male, generalizing to other populations must be done with care. This is not a problem 
in this study, however, for the desired comparisons are with other young males, those in the NLS.

\section{Studies of Training Success}

Most of the validity research has involved correlating scores on ASVAB tests taken prior to induction with final grades in MOS specific training courses (generally measured at least 4 months after induction). Since recruits are selected into the army and into the various specialties by a nonrandom process, mechanisms have been developed to correct for selection effects--what I/O psychologists call restriction of range (Thorndike 1949; Lord and Novick 1968; Dunbar and Linn 1986). These selection models assume that selection into a particular MOS is based on ASVAB subtest scores (and in some cases measures of the recruit's occupational interests). For the military environment, this appears to be a reasonable specification of the selection process for attrition is low and selection is indeed explicitly on observable test scores. This ability to model the selection process is an advantage that validity research in the military has over research in the civilian sector. ${ }^{4}$

A reanalysis was conducted of data from two large scale studies of Marine recruits (Sims and Hiatt 1981 reprinted in Hunter, Crossen and Friedman 1985; Maier and Truss 1985). These studies were selected because they used versions of the ASVAB that were quite similar to the one administered to the NLS Youth Cohort. Correlation matrices which had been corrected (for restriction of range and selection effects) were obtained from the appendices of these studies and LISREL was employed to estimate models in which training grades were regressed on the full set of ASVAB subtests. The standardized regression coefficients from this analysis are reported in table 7.

The estimation results are similar to the wage and earnings regressions in only one respect: technical competency as indexed by the mechanical, auto-shop and electronics subtests have major effects on success in training for occupations involving the maintenance or use of complicated equipment. In all other respects, however, the results contrast sharply with the wage rate regressions for young males. The math knowledge and arithmetic reasoning subtests have much larger effects on training success than the computational speed test. Both the science and verbal subtests have strong positive impacts on success in training. It appears that the higher level academic competencies measured by the ASVAB have much larger positive 
effects on success in training programs than on wage rates of young men in the civilian sector.

\section{Reanalysis of Maier and Grafton's Data on Job Performance}

Since, however, both the criterion--training success--and the predictors--competence in particular areas--are measured by paper and pencil tests, there is a danger that results may be biased by common methods bias. Therefore, it would be desireable to check these findings in a data set in which ASVAB subtest scores predict a hands-on measure of job performance. Maier and Grafton's (1981) study of ASVAB 6/7's ability to predict the hands-on Skill Qualification Test (SQTs) provides such a data set. Maier and Grafton described the handson SQTs they used in their study as follows:

SQTs are designed to assess performance of critical job tasks. They are criterion referenced in the sense that test content is based explicitly on job requirements and the meaning of the test scores is established by expert judgment prior to administration of the test rather than on the basis of score distributions obtained from administration. The content of SQTs is a carefully selected sample from the domain of critical tasks in a specialty. Tasks are selected because they are especially critical, such as a particular weapon system, or because there is a known training deficiency. The focus on training deficiencies means that relatively few on the job can perform the tasks, and the pass rate for these tasks therefore is expected to be low. Since only critical tasks in a specialty are included in SQTs, and then only the more difficult tasks tend to be selected for testing, a reasonable inference is that performance on the SQTs should be a useful indicator of proficiency on the entire domain of critical tasks in the specialty; that is, workers who are proficient on tasks included in an SQT are also proficient on other tasks in the specialty. The list of tasks in the SQT and the measure themselves are carefully reviewed by job experts and tried out on samples of representative job incumbents prior to operational administration. The process of developing SQTs may be characterized as follows:

1. Identify tasks for testing.

2. Identify behaviors or steps essential for performing each task.

3. Develop measures to cover essential behaviors, and have these measures reviewed by job experts.

4. Tryout the measures on representative workers to verify accuracy of measurement; i.e., make sure that measures discriminate between task performers and nonperformers.

After each step, the products are reviewed for content validity. The test content cannot be changed after step 3, when the measures are approved by experts. The tryout of step 4 can be used only to improve the measures, and not to change content. When the development process is followed, the validity of the 
SQTs as measures of job proficiency is assured by job experts and representative workers.(pp. 4-5)

A more extensive discussion of the procedures for developing SQTs is available in a handbook (Osborn et al, 1977). A thorough discussion of their rationale is provided in Maier and Hirshfeld (1978).

Correlation matrices relating the ASVAB subtests and SQTs were taken from Appendices A and B in Maier and Grafton (1981). The correlation matrices were corrected for selection effects and restriction of range by Maier and Grafton using procedures described in Dunbar and Linn (1986). Regressions were estimated using LISREL for eight major categories of Military Occupational Specialties (MOS): Skilled Technical, Skilled Electronic, General Maintenance, Mechanical Maintenance, Clerical, Operators (of Missile Batteries) and Food, Combat and Field Artillery. Except for combat and field artillery, these MOSs have close counterparts in the civilian sector. The independent variables were the 10 ASVAB $6 / 7$ subtest scores which had counterparts in the ASVAB 8A battery used in the analysis of NLS Youth. The standardized regression coefficients from this analysis are reported in Table 8. The effects of the four "technical" subtests--mechanical comprehension, auto information, shop information and electronics information--are presented in the first four columns of the table. The effects of these subtests on job performance are substantial in all of the nonclerical occupations. The impact of a one standard deviation increase in all four of these subtests is an increase in the SQT of $.415 \mathrm{SD}$ in skilled technical jobs, of $.475 \mathrm{SD}$ in skilled electronics jobs, of .316 SD in general maintenance jobs, .473 SD in mechanical maintenance jobs, of $.450 \mathrm{SD}$ for missile battery operators and food service workers, of $.345 \mathrm{SD}$ in combat occupations and .270 SD in field artillery. Note further that, in standard deviation units, the job performance effects of the technical subtests are much larger than their effects on training grades. Methods bias does seem to be at work. Clearly the technical competencies being measured by the four ASVAB technical subtests are important determinants of worker productivity in these jobs. This is consistent with the wage rate regression results.

The results for the academic subtests, however, contrast starkly with the wage rate regressions for young males. Science and word knowledge have substantial effects on job performance in skilled technical, general maintenance, clerical, operator/food and combat arms MOSs. With the sole exception of the mechanical maintenance MOS cluster, the two mathematical reasoning subtests have much larger effects on SQTs than the computational 
speed subtest. A one standard deviation increase in both of the mathematical reasoning subtests raises predicted job performance by $.183 \mathrm{SD}$ in skilled technical jobs, $.24 \mathrm{SD}$ in skilled electronic jobs, $.34 \mathrm{SD}$ in general maintenance jobs, $.447 \mathrm{SD}$ in clerical jobs, $.22 \mathrm{SD}$ for missile battery operators and food service jobs, .209 SD in combat arms and $.416 \mathrm{SD}$ in field artillery. Clearly, the two tests of mathematical reasoning have substantial effects on job performance. Nevertheless, the effects are somewhat smaller than those obtained in the models of success in training suggesting again the possibility of methods bias.

The attention to detail subtest (which is similar to the clerical checking subtest in ASVAB 8A) has no effect on performance in clerical jobs and small effects on performance in skilled electronic, general maintenance, combat arms and field artillery.

\section{Marine Rifleman Data}

The possibility of differences in validity patterns between hands-on tests and job knowledge tests can be explored further in data that Milton Maier has kindly made available on the correlations between ASVAB subtests and both types of performance measures for the same group of Marine Corps rifleman. This time the raw correlation matrix uncorrected for restriction of range and selection was available. It was assumed that selection into the sample was based on ASVAB test scores and unobservable factors that are uncorrelated with equation error, so regressions that include test scores as regressors should yield unbiased estimates of population parameters. The two dependent variables were normalized by dividing them by their standard deviation. For the ASVAB subtests the metric selected was the standard deviation of 18 to 23 year old men and women in the NLS Youth Cohort. The unstandardized regression coefficients from simple linear regressions are reported in Table 9.

The findings are quite consistent with the results of the reanalysis of Maier and Grafton's data. Technical competencies have much larger effects on hands-on work sample measures of performance than on paper and pencil job knowledge tests. For the rifleman job, technical competencies are clearly more powerful predictors of hands-on performance measures than academic competencies. Coefficients on the computational speed and word knowledge subtests are negative when hands-on performance is the criterion but positive when job knowledge is the criterion. Science and arithmetic reasoning have statistically significant effects on hands-on performance measures but the academic subtests have as a whole smaller 
impacts on work sample tests than on job knowledge tests. Here again, there is evidence of a paper-and-pencil methods bias. This implies that validity studies based solely on job knowledge tests may not result in a correct selection of subtests for the aptitude composites that are used for selection and classification of recruits.

\section{Project A Data: Core Technical Proficiency}

Still more evidence on what truly determines job performance comes from Project A, a massive study (total costs of more than $\$ 100,000,000$ ) that is developing improved methods for selecting and classifying army personnel. Wise, McHenry, Rossmeissl and Oppler (1987) have estimated ASVAB validities for 19 very diverse jobs using Core Technical Proficiency, a MOS specific job performance measures, as the criterion. These ratings are about 50 percent based on hands-on work sample tests (the hands-on SQT) and 50 percent based on paper and pencil job knowledge exams. The ratings were obtained after the recruit had been in the army for 2 to 3 years. The study was designed to select the three or four ASVAB subtests which could be used as the aptitude composite for that MOS cluster.

Table 10 reports the names of the three or four subtests which in combination did the best job of predicting Core Technical Proficiency. As before, the technical subtests are important predictors of Core Technical Proficiency in all the nonclerical occupations. For the academic subtests the results are very different from the wage rate regressions but similar to the results of the reanalysis of Maier and Grafton's validity data for hands-on work samples. Computational speed is only a weak determinant of job performance. Competence in science, language arts and mathematical reasoning has very large effects on job performance.

\section{Project A Data: Other Performance Measures}

Most of the ASVAB validity studies have studied MOS specific measures of performance which reflect the soldier's ability to do the job not their willingness to do it on a regular basis or under adverse conditions. Do the results change when other dimensions of job performance are studied? The Project A data set again provides an opportunity to address this issue. Besides the Core Technical Proficiency construct already analyzed, Project A offers three other performance constructs which have some applicability to civilian jobs: General 
Soldiering Proficiency, Effort and Leadership and Maintaining Personal Discipline. General Soldiering Proficiency assesses skills that all soldiers must have (eg. use of basic weapons, first aid, map reading, use of a gas mask) and is measured much the same way as Core Technical Proficiency by a combination of job knowledge tests and hands-on performance tests. These two constructs are designed to measure the can do element of job performance.

The other two constructs attempt to measure the will do element of job performance. John P. Campbell (1986) described the constructs and their measurement as follows:

Peer Leadership, Effort, and Self Development: Reflects the degree to which the individual exerts effort over the full range of job tasks, perseveres under adverse or dangerous conditions, and demonstrates leadership and support of peers. That is, can the individual be counted on to carry out assigned tasks, even under adverse conditions, to exercise good judgement, and to be generally dependable and proficient? Five scales from the Army-wide BARS rating form (Technical Knowledge/Skill, Leadership, Effort, Self-development, and Maintaining Assigned Equipment), the expected combat performance rating, and the total number of commendations and awards received by the individual were summed for this factor.

Maintaining Personal Discipline: Reflects the degree to which the individual adheres to Army regulations and traditions, exercises personal self-control, demonstrates responsibility in day-to-day behavior, and does not create disciplinary problems. Scores on this factor are composed of three Army-wide Bars scales (Following regulations, Self-Control, and Integrity) and two indices from the administrative records (number of disciplinary actions and promotion rate). (p. 150)

It had been planned to obtain information on commendations, awards, promotions, and disciplinary actions from administrative records. However, the cost of this approach was extremely high so "everyone crossed their fingers and we collected eight archival performance indicators via a self report questionnaire....Field tests on a sample of 500 people showed considerable agreement between self-report and archival records"(Campbell, 1986, p 144).

These two constructs are related to each other (they correlate .59) but are clearly quite distinct from the two "can do" constructs. Correlations with Core Technical Proficiency are only .28 for Effort and Leadership and .19 for Personal Discipline. The "can do" constructs are based on ratings made by the same person, so they share some common measurement error. Campbell, consequently, constructs residualized "can do" performance constructs by subtracting a ratings method factor from the raw score. With the ratings methods effect removed, Core Technical Proficiency (raw) has a correlation of .465 with Effort and 
Leadership (residual) and .225 with Personal Discipline (residual). In the view of the Project A team, soldiers must have both qualities--the technical competence to do their job and the willingness to do it under stressful circumstances.

Table 11 presents the results of using ASVAB test scores to predict General Soldiering Proficiency (raw), Effort and Leadership (both raw and residualized) and Personal Discipline (raw) (Campbell, 1986, Table 10). The correlation matrices were corrected for range restriction as described by Dunbar and Linn (1986). In this analysis the 9 ASVAB subtests have been reduced to four composites: Technical, Speed (Numerical Operations and Clerical Checking), Quantitative (Arithmetic Reasoning and Mathematics Knowledge) and Verbal/Science.

For General Soldiering Proficiency, the results are quite similar to the results obtained predicting Hands-on SQTs and Core Technical Proficiency. The technical and quantitative composites have the largest effects, and the verbal/science composite has a substantial effect. Speed has almost no effect. As before, the pattern of coefficients is very different from the wage regression for young men.

The pattern is different for the "will do" performance constructs. The technical composite had large positive effects on both measures of Effort and Leadership. The quantitative composite had a modest positive effect on Maintaining Personal Discipline and the residualized Effort and Leadership. Speed had a modest positive effect on Effort and Leadership. The verbal/science composite had no effect on the residualized Effort and Leadership and a small negative effect on raw score measures of both constructs. The coefficient pattern for the raw score "will do" performance constructs looks rather similar to the male wage and earnings regressions. This is an interesting result that needs to be investigated in other data sets. It should be treated with caution, however, for four reasons: the information on commendations, awards, promotions and disciplinary actions was self reported, a ratings method effect was clearly visible in the data, other researchers have expressed skepticism about the validity of military ratings (Vineberg and Joyner 1982), and there appears to be major differences between the civilian and military sectors in the effect of academic achievement tests on supervisory ratings (with the effects much larger in the civilian sector) $)^{5}$ (Hunter 1986). 
In any case, even if one adopts the Project A position that ratings are a valid measure of the "will do" component of job performance, this in no way implies that the "can do" elements are subsidiary or unimportant. Consequently, the findings reviewed above that science, verbal and mathematical reasoning capability predict hands-on SQTs, Core Technical Proficiency and General Soldiering Proficiency in the military imply that academic competencies of the type stressed by the Excellence Commission are probably important determinants of overall job performance in similar civilian jobs (eg. those involving the use, maintenance and repair of complicated machinery).

\section{SUMMARY AND CONCLUSIONS}

The high school graduating class of 1982 took on average only .43 credits of Algebra II, .31 credits of more advanced mathematics courses, .40 credits of chemistry and .19 credits of physics (Meyer 1988 Table A.2). The apparent cause of these low enrollment figures is the perception of most high school students that there is little connection between how much they learn in math and science courses and their future success in the labor market. Less than a quarter of 10th graders believe that geometry, trigonometry, biology, chemistry and physics are needed to qualify for their first choice occupation (Longitudinal Survey of American Youth 1988). The analysis of NLS data undertaken in this study demonstrates that this perception is generally correct. During the first 8 years after leaving high school, young men who do not go to college receive no rewards from the labor market for developing competence in science, language arts and mathematical reasoning. For young males, the only academic competency that appears to be rewarded by the labor market is speed in doing simple computations (something that calculators do better than people). The other competency that has major effects on the wages of young men is technical competence (knowledge of mechanical principles, electronics, automobiles and shop tools), something that has been ignored by the reports recommending educational reform.

For the non-college bound female, computational speed and competence in mathematical reasoning increase wage rates but competence in science, language arts and the technical arena does not. The tendency of so many American high school students to avoid tough math and science courses and their poor performance on international science and 
mathematics exams, therefore, appears to be a rational response to market incentives.

Educational reformers are claiming that improved math and science education for the great mass of high school students (not just the 10 percent who choose a career in natural science or engineering) is essential if the workforce is to become more productive. But, if people who are competent in math and science are more productive workers, why aren't employers paying them commensurately more? Employers fail to reward high school graduates who are competent in math and science because (1) they do not know which of the job applicants who approach them have these competencies and because (2) workers and employers prefer employment contracts in which wage rates adjust only partially to reflect outstanding performance. Consequently, when the specific competencies of students are not signaled to the labor market by a credential, there is little reason to expect the wage rate effects of specific competencies to be the same as their productivity effects.

Consequently, the productivity effects of competence in math and science must be measured more directly. This is done by analyzing a series of military data sets in which worker competencies have been correlated with hands-on measures of job performance. This analysis demonstrates that greater competence in science, language arts and higher level math is indeed associated with greater success in training and better performance on the job. These results provide support for the Excellence Commission's claim that major improvements in science and math education for the great mass of high school students will improve the productivity of the work force. The results also reinforce the findings regarding the important role of technical competence in blue collar, craft and technician jobs. This is an area of study that needs much more attention than it has been getting. 


\section{FOOTNOTES}

1. These subtests have some similarities with the occupational competency examinations developed to assess high school vocational students. However, the ASVAB technical subtests assess knowledge in a much broader domain and the individual items are, consequently, more generic and less detailed. The ASVAB technical composite is interpreted as a measure of knowledge and trainability for a large family of jobs involving the operation, maintenance and repair of complicated machinery and other technically oriented jobs.

2. Models were also estimated which did not constrain the main effects coefficients to be the same in all years and much the same results were obtained--eg positive interaction coefficients for computational speed but not for the academic composite. The ability measure in Hauser and Daymont's work was the Henmon-Nelson IQ test. A similar measure of ability can be constructed for NLS data by adding computational speed to the previously defined academic composite. When this composite is used to define the age-academic-competency interaction, the NLS data set yields findings that are similar to those obtained by Hauser and Daymont. Positive coefficients (many of which are significant) are obtained on this interaction variable. What this paper demonstrates is that when computational speed is allowed to have its own separate effects on labor market success, it is computational speed not other academic competencies which has growing effects on wages and earnings as the individual ages. Why this occurs is a puzzle. The issue clearly needs further research.

3. Bishop, Blakemore and Low's (1985) studied the effect of math, reading and vocabulary test scores on the wage rates and earnings of high school graduates for both 1972 and 1980 in a model that contained controls for grade point average and the number of credit hours of academic and vocational courses. In both these years, none of the variables representing academic performance--the three test scores, GPA and the number of academic courses--had a significant (at the ten percent level) effect on the wage rate of the first post high school job. Only one variable (the vocabulary test for female members of the class of 1972) had a significant effect on the wage 18 months after graduation.

4. If hiring selections were based entirely on $X$ variables included in the model, unstandardized coefficients would be unbiased and simple correction formulas are available for calculating standardized coefficients and validities. Unfortunately, in the civilian sector incidental selection based on unobservables such as interview performance and recommendations is very probable (Thorndike 1949; Olson and Becker 1983; Mueser and Maloney 1987). Consequently, in a sample of accepted applicants for a civilian job, one cannot be confident that these omitted unobservable variables are uncorrelated with the included variables that were used to make initial hiring decisions and, therefore, that coefficients on included variables are unbiased. When someone with 10 years of formal schooling is hired for a job that normally requires an associates degree, there is probably a reason for that decision. The employer saw something positive in that job applicant (maybe the applicant received a particularly 
strong recommendation from previous employers) that led to the decision to make an exception to the rule that new hires should have an associates degree. The analyst is unaware of the positive recommendations, does not include them in the job performance model and, as a result, the coefficient on schooling is biased toward zero. This phenomenon also causes the estimated effects of other worker traits used to select workers for the job such as previous relevant work experience to be biased toward zero. Variables which were not used to select new hires such as test scores will probably have a positive correlation with the unobservable. Since the unobservable probably has its own independent effect on job performance (ie. it is not serving solely as a proxy for test scores), test score coefficients are likely to be positively biased. Mueser and Maloney (1987) experimented with some plausible assumptions regarding this selection process and concluded that coefficients on education were severely biased but that test validities were not substantially changed when these incidental selection effects are taken into account.

5. Bishop (1988c) analysis of the GATB Revalidation Data on 31,000 workers in 247 civilian occupations found that verbal and mathematical reasoning capability and computational speed had very substantial effects on supervisory ratings. 


\section{Bibliography}

Bishop, John H. "The Recognition and Reward of Employee Performance." Journal of Labor Economics, Vol. 5, No. 4, pt 2, October 1987a, pp. S36-S56.

Bishop, John H. "Information Externalities and the Social Payoff to Academic Achievement." Center for Advanced Human Resource Research Discussion Paper \# 87-06, Cornell Univ. 1987b.

Bishop, John H. "Match Quality, Turnover and Wage Growth." Center for Advanced Human Resource Research Discussion Paper \# 88-03, Cornell Univ. 1988a.

Bishop, John H. "Vocational Education for At-Risk Youth: How to Make it More Effective." Center for Advanced Human Resource Research Discussion Paper \# 88-11, Cornell Univ. 1988b.

Bishop, John H. "The Economics of Employment Testing" Center for Advanced Human Resource Research Discussion Paper \# 88-14, Cornell Univ. 1988c, forthcoming in Testing and Public Policy, edited by Bernard Gifford.

Bishop, John; Blakemore, Arthur; Low, Stuart. "High School Graduates in the Labor Market: A Comparison of the Class of 1972 and 1980." Columbus, Ohio: National Center for Research in Vocational Education, 1985.

Bishop, John and Griffin, Kelly. Recruitment, Training and Skills of Small Business Employees, (National Federation of Independent Business Foundation, Washington, DC, forthcoming).

Booth-Kewley, S. (1983). Predictive validation of Armed Services Vocational Aptitude Battery forms 8, 9, and 10 against performance at 47 Navy schools. San Diego, CA: Navy Personnel Research and Development Center.

Campbell, John P. "Validation Analysis for New Predictors" Paper presented at Data Analysis Workshop of the Committee on the Performance of Military Personnel, Baltimore, December 1986.

Dunbar, Stephen B., and Linn, Robert L. Range Restriction Adjustments in the Prediction of Military Job Performance. Committee on the Performance of Military Personnel. Commission on Behavioral and Social Sciences and Education. National Research Council/National Academy of Sciences, September, 1986.

Frank, Robert. "Are Workers Paid Their Marginal Product?" American Economic Review, Vol. 74:4, September 1984, 549-571. 
Friedman, Toby and Williams, E. Belvin. "Current Use of Tests for Employment." Ability Testing: Uses, Consequences, and Controversies, Part II: Documentation Section, edited by Alexandria K. Wigdor and Wendell R. Gardner. Washington, DC: National Academy Press, 1982, pg. 999-169.

Gardner, John A. Influence of High School Curriculum on Determinants of Labor Market Experience. Columbus: The National Center for Research in Vocational Education, The Ohio State University, 1982.

Hashimoto, M., and Yu, B. "Specific Capital, Employment and Wage Rigidity." Bell Journal of Economics, 11, no. 2, 1980: 536-549.

Hause, J. C. "Ability and Schooling as Determinants of Lifetime Eamings, or If You're So Smart, Why Aren't You Rich." In Education, Income, and Human Behavior; edited by F. T. Juster. New York: McGraw-Hill, 1975.

Hauser, Robert M. and Daymont, Thomas M. "Schooling, Ability, and Earnings: CrossSectional Evidence 8-14 years after High School Graduation." Sociology of Education, July $1977, \underline{50}, 182-206$.

Hollenbeck, K., and Smith B. The Influence of Applicants' Education and Skills on Employability Assessments by Employers. Columbus: The National Center for Research in Vocational Education, The Ohio State University, 1984.

Hotchkiss, Lawrence; Bishop, John H.; and Gardner, John. Effects of Individual and School Characteristics on Part-Time Work of High School Seniors. Columbus: The National Center for Research in Vocational Education, The Ohio State University, 1982.

Hunter, John. "Cognitive Ability, Cognitive Aptitudes, Job Knowledge and Job Performance." Journal of Vocational Behavior, Vol. 29, No. 3, December 1986. pp. 340-362.

Hunter, John E.; Crosson, James J. and Friedman, David H. "The Validity of the Armed Services Vocational Aptitude Battery (ASVAB) For Civilian and Military Job Performance, Department of Defense, Washington, D.C., August, 1985.

Hunter, John E.; Schmidt, Frank L. and Judiesch, Michael K. "Individual Differences in Output as a Function of Job Complexity." Department of Industrial Relations and Human Resources, University of Iowa, June 1988.

International Association for the Evaluation of Educational Achievement (IEA) Science Achievement in Seventeen Nations, New York, Pergammon Press, 1988

Kang, Suk and Bishop, John. "The Effect of Curriculum on Labor Market Success Immediately After High School" Journal of Industrial Teacher Education, Spring, 1986. 
Lazear, Edward P. "Pay Equality and Industrial Politics", The Hoover Institution, Stanford University, April 1986.

Longitudinal Survey of American Youth. "Data File User's Manual" Dekalb, Ill: Public Opinion Laboratory, 1988.

Lord, F. \& Novick, M. (1968). Statistical theories of mental test scores. Reading, MA: Addison-Wesley.

Maier, Milton H.; and Grafton, Francis. "Aptitude Composites for the ASVAB 8, 9 and 10." Research Report 1308, U. S. Army Research Institute for the Behavioral and Social Sciences, Alexandria, VA. May, 1981.

Maier, M.H., \& Truss, A.R. (1983). Validity of the ASVAB forms 8, 9, and 10 for Marine Corps training courses: Subtests and current composites (Memorandum No. 83-1307). Alexandria, VA: Center for Naval Analyses.

Maier, M.H. \& Truss, A.R. (1985). Validity of the Armed Services Vocational Aptitude Battery Forms 8, 9, and 10 with Applications to Forms 11, 12, 13, and 14. (CNR 102). Alexandria, VA: Center for Naval Analyses.

Maier, M. H. and Hirshfeld, S. F. Criterion Referenced Testing: A Large Scale Application. Technical Research Report 1193, Alexandria, Virginia: Army Research Institute, February 1978.

McKnight, Curtis C. et al. The Underachieving Curriculum: Assessing US School Mathematics from an International Perspective. A National Report on the Second International Mathematics Study. Stipes Publishing Co.: Champaign, Il, January 1987.

McLaughlin, D., Rossmeissl, P., Wise, L., Brandt, D., \& Wang, M. (1984). Validation of current and alternative ASVAB Area Composites, based on training and SQT information on FY 1981 and FY 1982 Enlisted Accessions (Technical Report 651). Alexandria, VA: U.S. Army Research Institute.

Meyer, Robert. "Job Training in the Schools." In Job Training for Youth, edited by R. Taylor, H. Rosen, and F. Pratzner. Columbus: The National Center for Research in Vocational Education, The Ohio State University, 1982.

Meyer, Robert. "Applied versus Traditional Mathematics: New Econometric Models of the Contribution of High School Courses to Mathematics Proficiency." National Assessment of Vocational Education, September, 1988.

Mueser, Peter and Maloney, Tim. "Cognitive Ability, Human Capital and Employer Screening: Reconciling Labor Market Behavior with Studies of Employee Productivity." Department of Economics, U. of Missouri-Columbia, June 1987. 
National Assessment of Educational Progress. The Science Report Card. Princeton, New Jersey: Educational Testing Service, 1988a.

National Assessment of Educational Progress. The Mathematics Report Card. Princeton, New Jersey: Educational Testing Service, 1988b.

National Commission on Excellence in Education. A Nation at Risk: The Imperative for Educational Reform. A report to the nation and the Secretary of Education. Washington, DC: Government Printing Office, April 1983.

National Council of Teachers of Mathematics. An Agenda for Action: Recommendations for School Mathematics of the 1980s. Washington DC: National Council of Teachers of Mathematics, 1980.

Noah, Harold J.and Eckstein, Max A. "Tradeoffs in Examination Policies: An International Perspective." Paper presented at the Annual Meeting of the British Comparative and International Education Society, University of Bristol, September 15-17, 1988.

Olson, Craig A and Becker, Brian E. "A Proposed Technique for the Treatment of Restriction of Range in Selection Validation." Psychological Bulletin. Vol. 93, No 1, 1983, pp. 137-148.

Osborn, W. C., Campbell, R. C., Ford, J. P., Hirshfeld, S. F., and Maier, M. H. Handbook for the Development of Skill Qualification Tests. Technical Report P-77-5. Alexandria, Virginia: Army Research Institute, November, 1977.

Palmer, Pamla; Hartke, Darrell D.; Ree, Malcolm James; Welsh, John R.; Valentine, Lonnie D. "Armed Services Vocational Aptitude Battery (ASVAB): Alternate Forms Reliability (Forms 8, 9, 10 and 11)." Brooks Air Force Base, Texas: Air Force Systems Command, Air Force Human Resources Laboratory, March 1988.

Rosenbaum, James and Kariya, Tobe. "Market and Institutional Mechanisms for the High School to Work Transition in Japan and the U.S. Paper given at the August 1987 American Sociological Association Meeting.

Rossmeissl, P.G., Martin, C.J., \& Wing, H. (1983). Validity of ASVAB 8, 9, and 10 as predictors of training success (Selection and Classification Working Paper No. 83-3). Alexandria, VA: Army Research Institute for the Behavioral and Social Sciences.

Sims, W. H. and Hiatt, C. M., Validation of the Armed Services Vocational Aptitude Battery (ASVAB) Forms 6 and 7 with Applications to ASVAB Forms 8, 9, and 10. Marine Corps Operations Analysis Group, CNS 1160, Center for Naval Analysis, Alexandria, VA, 1981.

Stiglitz, Joseph E. "Risk Sharing and Incentives in Sharecropping." Review of Economic Studies, 61, no. 2 April 1974, 219-256. 
Thorndike, R. L. Personnel Selection: Test and Measurement Techniques. New York: Wiley, 1949.

Taubman, P. and Wales, T. "Education as an Investment and a Screening Device." In Education, Income, and Human Behavior, edited by F. T. Juster. New York: McGraw-Hill, 1975.

U.S. Department of Defense. (1984a). Military-civilian occupational crosswalk manual. Washington, DC: Office of the Assistant Secretary of Defense (Manpower, Installations and Logistics).

U.S. Military Entrance Processing Command. Counselor's Manual for the Armed Services Vocational Aptitude Battery, Form 14. July, 1984.

Wigdor, Alexandra K. "Psychological Testing and the Law of Employment Discrimination." Ability Testing: Uses, Consequences, and Control, edited by Alexandra K. Wigdor, 1982. ERIC Document 213771.

Wilbourn, J.M., Valentine, L.D., \& Ree, M.J. (1984). Relationships of the Armed Services Vocational Aptitude Battery (ASVAB) forms 8.9, and 10 to Air Force technical school final grades (AFHRL-TP-84-08). Brooks Air Force Base, TX: Air Force Human Resources Laboratory.

Willis, Robert and Rosen, Sherwin. "Education and Self-Selection." Journal of Political Economy, 87, October 1979, pg. 57-536.

Wise, David A. "Academic Achievement and Job Performance." The American Economic Review, June 1975, Vol. 65, No. 3, pp.350-366.

Wise, L., McHenry, J., Rossmeissl, P. \& Oppler, S. (1987). ASVAB Validities using Improved Job Performance Measures. American Institutes For Research, Washington, DC. 
Table 1

Effect of Competencies on Log Wage Rate

\begin{tabular}{|c|c|c|c|c|c|c|c|c|c|c|}
\hline & & Comntational & & & & & & $\begin{array}{l}\text { F Test } \\
\text { Academic }\end{array}$ & $\begin{array}{l}\text { F Test } \\
\text { Academic }\end{array}$ & $\begin{array}{l}\text { F Test } \\
\text { Academic }\end{array}$ \\
\hline Technical & Speed & Speed & Math & Verbal & Science & $\mathrm{R}^{2}$ & $\mathbf{N}$ & $\begin{array}{r}\text { vs. } \\
\text { Zero }\end{array}$ & $\begin{array}{l}\text { vs. } \\
\text { Tech }\end{array}$ & $\begin{array}{l}\text { vs. } \\
\text { Comp }\end{array}$ \\
\hline
\end{tabular}

Male

1986

1985

(6.10)

.005

$-.007$

$-.021$

$-.008$

.264

4272

4.35

17.3

18.4

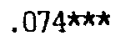

.004

$.064 * \star \star *$

.270

4206

.66

10.2

11.5

1984

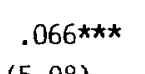

.006

$(5.84)$

(.57)

(1.08) (.43)

239

(6.38)

.005
$(.42)$

$-.015$

$-.014$

.239

4527

2.05

10.8

17.2

1983

$.063 * \star \star \quad .004$

$.068 * \star \star$
$(6.27)$

$-.025 * \star$

$-.036 * \star$

.018

.245

4401

6.55

15.2

1982

$.051 \star \star \star \quad .006$

$.041 * \star \star$

$-.014$

$-.011$

$-.010$

.220

4477

4.6

10.3

11.9

1981

$.033 \star \star \star \quad-.001$

$.050^{\star \star \star}$

(1.16)

(.78)

(.77)

.238

3881

4.4

6.4

14.3

1980

$.048 * \star \star \quad-.011$

$.039 \star \star \star$

(.10)

$(.63)$

(1.83)

.225

3552

10.8

14.3

16.9

1979

(1.00)

(3.48)

(2.01)

-.006
$(.42)$

(1.75)

$-.004$

$-.003$

$-.027$

.248

2249

1.6

3.3

3.9

Female

1986

$\begin{array}{ll}.006 & .028^{\star \star \star} \\ (.31) & (2.60)\end{array}$

$.024^{\star \star}$

$.027 * \quad .027 *$

.012

$.275 \quad 4080$

12.6

3.3

3.0

1985

$-.016$

(.91)

$.029 \star \star \star$

(2.04)

(1.94)

(1. .75)

(.81)

$\begin{array}{lr}.042^{\star \star *} & .030^{*} \\ (3.06) & (1.95)\end{array}$

.005

$.256 \quad 3965$

17.9

8.1

5.4

1984

.008
$(.48)$

.008

(1.82)

(1.95) (.36)

$.231 \quad 4159$

8.1

1.8

.3

1983

$-.013$

$(.78)$

(3.26)

$(3.56)$

$\begin{array}{ll}.004 & (.07)\end{array}$

$.042^{\star \star \star \star}$

$.045 * \star \star$

009

$-.003$

(3.49) (.63) (.19)

.204

4054

8.8

4.3

.2

1982

.017

(.97)

(3.82)

.020

.002

$-.017$

.184

4037

.1

.1

2.1

1981

(1.03)

(1.56)

(3.55)

(1.62)

(.17)

(1.30)

$.190 \quad 3481$

.8

(2.82)

(.11)

.018

$-.004$

$-.013$

(.27)

.018
(1.28)

-.013
$(.81)$

$.030 * \star$
$(1.98)$

$.150 \quad 3173$

3.4 
Table 2

Effects of Competencies on Log Earnings

\begin{tabular}{|c|c|c|c|c|c|c|c|c|c|c|c|}
\hline & Technical & $\begin{array}{c}\text { Clerical } \\
\text { Speed }\end{array}$ & $\begin{array}{c}\text { Computational } \\
\text { Speed }\end{array}$ & Effects of & Verbal & Science & $\mathrm{R}^{2}$ & $\mathbf{N}$ & $\begin{array}{l}\text { F Test } \\
\text { Acadenic } \\
\text { vs. } \\
\text { Zerọ }\end{array}$ & $\begin{array}{c}\text { F Test } \\
\text { Bcadenic } \\
\text { vs. } \\
\text { Tech }\end{array}$ & $\begin{array}{l}\text { F Test } \\
\text { Academic } \\
\text { vs. } \\
\text { Comp. }\end{array}$ \\
\hline \multicolumn{12}{|l|}{ Male } \\
\hline 1985 & $\begin{array}{l}.133^{\star \star \star} \\
(6.26)\end{array}$ & $\begin{array}{l}.004 \\
(.21)\end{array}$ & $\begin{array}{l}.119^{\star \star \star} \\
(6.55)\end{array}$ & $\begin{array}{l}-.037 \star \\
(1.78)\end{array}$ & $\begin{array}{l}.014 \\
(.61)\end{array}$ & $\begin{array}{r}-.021 \\
(.93)\end{array}$ & .358 & 4521 & 2.4 & 15.3 & 18.3 \\
\hline 1984 & $\begin{array}{l}.115^{\star \star \star} \\
(5.38)\end{array}$ & $\begin{array}{l}.017 \\
(.98)\end{array}$ & $\begin{array}{l}.089 \star \star \star \\
(4.89)\end{array}$ & $\begin{array}{r}-.002 \\
(.09)\end{array}$ & $\begin{array}{l}.009 \\
(.37)\end{array}$ & $\begin{array}{r}-.003 \\
(.14)\end{array}$ & .372 & 4564 & 0.0 & 6.0 & 5.1 \\
\hline 1983 & $\begin{array}{l}.018^{\star \star \star} \\
(5.08)\end{array}$ & $\begin{array}{c}.027 \\
(1.52)\end{array}$ & $\begin{array}{l}.110^{\star \star \star} \\
(6.21)\end{array}$ & $\begin{array}{r}-.014 \\
(.69)\end{array}$ & $\begin{array}{c}.028 \\
(1.21)\end{array}$ & $\begin{array}{l}-.025 \\
(1.14)\end{array}$ & .376 & 5004 & .1 & 7.1 & 10.9 \\
\hline 1982 & $\begin{array}{l}.120^{\star \star \star} \\
(5.56)\end{array}$ & $\begin{array}{l}.013 \\
(.72)\end{array}$ & $\begin{array}{l}.133^{\star \star \star} \\
(7.32)\end{array}$ & $\begin{array}{l}-.036^{\star} \\
(1.77)\end{array}$ & $\begin{array}{r}-.007 \\
(.31)\end{array}$ & $\begin{array}{r}-.020 \\
(.88)\end{array}$ & .416 & 4959 & 5.1 & 16.2 & 27.1 \\
\hline 1981 & $\begin{array}{l}.131^{\star \star \star} \\
(5.96)\end{array}$ & $\begin{array}{c}.018 \\
(1.01)\end{array}$ & $\begin{array}{l}.111^{\star \star \star} \\
(6.00)\end{array}$ & $\begin{array}{l}-.054 \star \star \\
(2.55)\end{array}$ & $\begin{array}{r}-.001 \\
(.05)\end{array}$ & $\begin{array}{l}-.032 \\
(1.39)\end{array}$ & .400 & 4574 & 9.4 & 22.1 & 26.7 \\
\hline 1980 & $\begin{array}{l}.151^{\star \star *} \\
(6.66)\end{array}$ & $\begin{array}{c}.042^{\star \star} \\
(2.26)\end{array}$ & $\begin{array}{l}.087 \star \star \star \\
(4.49)\end{array}$ & $\begin{array}{r}-.009 \\
(.42)\end{array}$ & $\begin{array}{l}-.052^{\star \star} \\
(2.07)\end{array}$ & $\begin{array}{l}-.079 \star \star \star \\
(3.27)\end{array}$ & .392 & 3955 & 22.2 & 36.3 & 31.9 \\
\hline 1979 & $\begin{array}{l}.114^{\star \star \star} \\
(4.85)\end{array}$ & $\begin{array}{l}.017 \\
(.86)\end{array}$ & $\begin{array}{l}.082^{\star \star \star} \\
(4.11)\end{array}$ & $\begin{array}{l}-.034 \\
(1.57)\end{array}$ & $\begin{array}{l}-.058^{\star \star} \\
(2.20)\end{array}$ & $\begin{array}{r}-.023 \\
(.91)\end{array}$ & .380 & 3411 & 14.5 & 21.4 & 23.2 \\
\hline \multicolumn{12}{|c|}{ Female } \\
\hline 1985 & $\begin{array}{r}-.020 \\
(.64)\end{array}$ & $\begin{array}{c}.022 \\
(1.14)\end{array}$ & $\begin{array}{l}.053^{\star * \star} \\
(2.60)\end{array}$ & $\begin{array}{l}.065^{\star \star \star} \\
(2.66)\end{array}$ & $\begin{array}{c}.039 \\
(1.40)\end{array}$ & $\begin{array}{l}.009 \\
(.34)\end{array}$ & .328 & 3888 & 11.8 & 5.1 & 1.9 \\
\hline 1984 & $\begin{array}{c}.032 \\
(1.03)\end{array}$ & $\begin{array}{c}.038^{\star \star} \\
(2.06)\end{array}$ & $\begin{array}{l}.057^{\star \star \star} \\
(2.79)\end{array}$ & $\begin{array}{l}.053^{\star \star} \\
(2.20)\end{array}$ & $\begin{array}{l}.073^{\star \star \star} \\
(2.70)\end{array}$ & $\begin{array}{l}-.040 \\
(1.58)\end{array}$ & .368 & 3893 & 7.2 & .9 & .5 \\
\hline 1983 & $\begin{array}{l}.025 \\
(.82)\end{array}$ & $\begin{array}{l}.058 * \star \star \\
(3.09)\end{array}$ & $\begin{array}{l}.085^{\star \star \star} \\
(4.11)\end{array}$ & $\begin{array}{l}.052^{\star \star} \\
(2.16)\end{array}$ & $\begin{array}{c}.045 \\
(1.62)\end{array}$ & $\begin{array}{r}-.010 \\
(.37)\end{array}$ & .833 & 4134 & 7.3 & 1.2 & 0.0 \\
\hline 1982 & $\begin{array}{r}-.020 \\
(.65)\end{array}$ & $\begin{array}{r}.035^{\star} \\
(1.88)\end{array}$ & $\begin{array}{l}.053^{\star \star} \\
(2.55)\end{array}$ & $\begin{array}{l}.064^{\star \star \star} \\
(2.72)\end{array}$ & $\begin{array}{l}.105^{\star \star \star} \\
(3.72)\end{array}$ & $\begin{array}{l}-.048^{\star} \\
(1.83)\end{array}$ & .344 & 4101 & 14.3 & 2.6 & 6.1 \\
\hline 1981 & $\begin{array}{l}-.033 \\
(1.07)\end{array}$ & $\begin{array}{l}.039 \star \star \\
(2.05)\end{array}$ & $\begin{array}{c}.021 \\
(1.01)\end{array}$ & $\begin{array}{l}.059 * \star \\
(2.47)\end{array}$ & $\begin{array}{l}.119 \star \star \star \\
(4.21)\end{array}$ & $\begin{array}{l}-.039 \\
(1.51)\end{array}$ & .332 & 3843 & 17.4 & 8.5 & 7.2 \\
\hline 1980 & $\begin{array}{l}.021 \\
(.66)\end{array}$ & $\begin{array}{l}.042^{\star \star} \\
(2.23)\end{array}$ & $\begin{array}{l}.084^{\star \star \star} \\
(3.99)\end{array}$ & $\begin{array}{c}.037 \\
(1.55)\end{array}$ & $\begin{array}{c}.036 \\
(1.26)\end{array}$ & $\begin{array}{l}-.038 \\
(1.42)\end{array}$ & .333 & 3409 & 1.1 & 0.1 & 1.3 \\
\hline 1979 & $\begin{array}{l}.019 \\
(.59)\end{array}$ & $\begin{array}{c}.049 \star \star \\
(2.50)\end{array}$ & $\begin{array}{l}.097^{\star \star \star \star} \\
(4.41)\end{array}$ & $\begin{array}{r}-.022 \\
(.89)\end{array}$ & $\begin{array}{l}.017 \\
(.58)\end{array}$ & $\begin{array}{r}-.006 \\
(.21)\end{array}$ & .333 & 2886 & .1 & 0.2 & 5.4 \\
\hline
\end{tabular}


Table 3

Effects of Competencies on Earnings (\$)

\begin{tabular}{|c|c|c|c|c|c|c|c|c|c|c|c|}
\hline & Technical & $\begin{array}{l}\text { Clerical } \\
\text { Speed }\end{array}$ & $\begin{array}{l}\text { Computational } \\
\text { Speed }\end{array}$ & Math & Verbal & Science & $R^{2}$ & N & $\begin{array}{l}\text { F Test } \\
\text { Acadenic } \\
\text { vs. } \\
\text { Zero }\end{array}$ & $\begin{array}{c}\text { F Test } \\
\text { Academic } \\
\text { vs. } \\
\text { Tech }\end{array}$ & $\begin{array}{l}\text { F Test } \\
\text { Academic } \\
\text { vs. } \\
\text { Comp }\end{array}$ \\
\hline Male & & & & & & & & & & & \\
\hline 1985 & $\begin{array}{l}1365 \star \star \star \\
(5.42)\end{array}$ & $\begin{array}{c}251 \\
(1.39)\end{array}$ & $\begin{array}{l}1241 * \star \star \\
(5.85)\end{array}$ & $\begin{array}{c}-96 \\
(.39)\end{array}$ & $\begin{array}{c}-87 \\
(.32)\end{array}$ & $\begin{array}{l}-218 \\
(.84)\end{array}$ & .350 & 4900 & 1.5 & 10.9 & 13.6 \\
\hline 1984 & $\begin{array}{l}1321^{\star \star \star} \\
(5.96)\end{array}$ & $\begin{array}{c}96 \\
(.53)\end{array}$ & $\begin{array}{l}1035 \star \star \star \\
(5.54)\end{array}$ & $\begin{array}{c}14 \\
(.06)\end{array}$ & $\begin{array}{l}-213 \\
(.89)\end{array}$ & $\begin{array}{l}-30 \\
(.13)\end{array}$ & .350 & 5007 & 0.6 & 10.9 & 10.4 \\
\hline 1983 & $\begin{array}{l}1228^{\star \star \star} \\
(6.89)\end{array}$ & $\begin{array}{c}307 \star \star \\
(2.10)\end{array}$ & $\begin{array}{l}1053^{\star \star \star \star} \\
(7.05)\end{array}$ & $\begin{array}{l}-141 \\
(.82)\end{array}$ & $\begin{array}{c}-194 \\
(1.00)\end{array}$ & $\begin{array}{l}-158 \\
(.86)\end{array}$ & .367 & 5642 & 4.5 & 20.9 & 24.6 \\
\hline 1982 & $\begin{array}{l}1114^{\star \star \star} \\
(6.71)\end{array}$ & $\begin{array}{c}280 \star \star \\
(2.06)\end{array}$ & $\begin{array}{l}926 \star \star \star \\
(6.65)\end{array}$ & $\begin{array}{r}-304 \star \\
(1.92)\end{array}$ & $\begin{array}{r}-314^{*} \\
(1.74)\end{array}$ & $\begin{array}{c}-187 \\
(1.08)\end{array}$ & .354 & 5742 & 14.2 & 30.2 & 35.9 \\
\hline 1981 & $\begin{array}{c}937 * \star \star \\
(6.06)\end{array}$ & $\begin{array}{l}330 * \star \star \\
(2.60)\end{array}$ & $\begin{array}{c}665 * \star \star \\
(5.07)\end{array}$ & $\begin{array}{l}-360 \star \star \\
(2.43)\end{array}$ & $\begin{array}{c}-76 \\
(.45)\end{array}$ & $\begin{array}{c}-278^{\star} \\
(1.73)\end{array}$ & .355 & 5237 & 12.9 & 25.8 & 26.2 \\
\hline 1980 & $\begin{array}{l}912^{\star \star \star} \\
(6.69)\end{array}$ & $\begin{array}{r}219 * \\
(1.95)\end{array}$ & $\begin{array}{c}493^{\star \star \star \star} \\
(4.28)\end{array}$ & $\begin{array}{c}-207 \\
(1.58)\end{array}$ & $\begin{array}{l}-109 \\
(.73)\end{array}$ & $\begin{array}{l}-428 * \star \star \\
(2.99)\end{array}$ & .344 & 4543 & 17.7 & 32.8 & 26.8 \\
\hline 1979 & $\begin{array}{l}580 \star \star \star \\
(4.42)\end{array}$ & $\begin{array}{c}41 \\
(.38)\end{array}$ & $\begin{array}{l}457^{\star \star \star} \\
(4.14)\end{array}$ & $\begin{array}{l}-375^{\star \star \star} \\
(3.08)\end{array}$ & $\begin{array}{r}-241^{*} \\
(1.67)\end{array}$ & $\begin{array}{c}89 \\
(.65)\end{array}$ & .320 & 3836 & 10.0 & 16.3 & 19.0 \\
\hline Female & & & & & & & & & & & \\
\hline 1985 & $\begin{array}{l}-171 \\
(.78)\end{array}$ & $\begin{array}{r}241 * \\
(1.90)\end{array}$ & $\begin{array}{l}438 * \star \star \\
(3.22)\end{array}$ & $\begin{array}{l}813 \star \star \star \\
(4.82)\end{array}$ & $\begin{array}{c}95 \\
(.51)\end{array}$ & $\begin{array}{c}30 \\
(.17)\end{array}$ & .405 & 5150 & 17.7 & 7.6 & 2.9 \\
\hline 1984 & $\begin{array}{l}129 \\
(.71)\end{array}$ & $\begin{array}{c}160 \\
(1.52)\end{array}$ & $\begin{array}{l}441^{\star \star \star} \\
(3.89)\end{array}$ & $\begin{array}{l}655 * \star \star \\
(4.67)\end{array}$ & $\begin{array}{c}199 \\
(1.30)\end{array}$ & $\begin{array}{c}-152 \\
(1.05)\end{array}$ & .441 & 5254 & 14.5 & 2.9 & 1.1 \\
\hline 1983 & $\begin{array}{r}292^{\star} \\
(1.70)\end{array}$ & $\begin{array}{c}275^{\star \star} \\
(2.71)\end{array}$ & $\begin{array}{l}541 \star \star \star \\
(4.94)\end{array}$ & $\begin{array}{l}541^{\star \star \star} \\
(4.06)\end{array}$ & $\begin{array}{c}178 \\
(1.21)\end{array}$ & $\begin{array}{l}-137 \\
(.97)\end{array}$ & .371 & 5112 & 10.8 & .8 & .0 \\
\hline 1982 & $\begin{array}{c}202 \\
(1.29)\end{array}$ & $\begin{array}{r}159 * \\
(1.70)\end{array}$ & $\begin{array}{l}306 \star \star \star \\
(3.03)\end{array}$ & $\begin{array}{l}447 \star \star \star \\
(3.69)\end{array}$ & $\begin{array}{r}333 * \\
(2.46)\end{array}$ & $\begin{array}{l}-56 \\
(.43)\end{array}$ & .360 & 5773 & 20.3 & 3.2 & 3.8 \\
\hline 1981 & $\begin{array}{c}185 \\
(1.32)\end{array}$ & $\begin{array}{l}325 * \star \star \\
(3.86)\end{array}$ & $\begin{array}{c}180^{\star \star} \\
(1.98)\end{array}$ & $\begin{array}{l}324 \star \star \star \\
(2.97)\end{array}$ & $\begin{array}{c}409 \star \star \star \\
(3.36)\end{array}$ & $\begin{array}{c}-248^{\star \star} \\
(2.14)\end{array}$ & .346 & 5384 & 11.0 & 1.3 & 2.5 \\
\hline 1980 & $\begin{array}{c}158 \\
(1.30)\end{array}$ & $\begin{array}{l}268^{\star \star \star} \\
(3.71)\end{array}$ & $\begin{array}{l}310^{\star \star \star} \\
(3.91)\end{array}$ & $\begin{array}{c}139 \\
(1.48)\end{array}$ & $\begin{array}{c}250 * \star \\
(2.37)\end{array}$ & $\begin{array}{c}123 \\
(1.22)\end{array}$ & .330 & 4758 & 4.4 & 0.2 & 0.1 \\
\hline 1979 & $\begin{array}{c}171 \\
(1.45)\end{array}$ & $\begin{array}{l}288 \star \star \star \star \\
(4.10)\end{array}$ & $\begin{array}{l}273^{\star \star \star} \\
(3.53)\end{array}$ & $\begin{array}{c}-68 \\
(.75)\end{array}$ & $\begin{array}{c}141 \\
(1.37)\end{array}$ & $\begin{array}{c}-37 \\
(.37)\end{array}$ & .318 & 4024 & .1 & .4 & 2.1 \\
\hline
\end{tabular}


Table 4

Effects of Campetencies on Unemployment

\begin{tabular}{|c|c|c|c|c|c|c|c|c|c|c|c|}
\hline & Technical & $\begin{array}{c}\text { Clerical } \\
\text { Speed }\end{array}$ & $\begin{array}{c}\text { Computational } \\
\text { Speed }\end{array}$ & Math & Verbal & Science & $\mathbf{R}^{2}$ & N & $\begin{array}{c}\text { Academic } \\
\text { vs. } \\
\text { Zero }\end{array}$ & $\begin{array}{c}\text { Academic } \\
\text { vs. } \\
\text { Tech }\end{array}$ & $\begin{array}{c}\text { Acadenic } \\
\text { vs. } \\
\text { Comp }\end{array}$ \\
\hline \multicolumn{12}{|l|}{ Male } \\
\hline 1985 & $\begin{array}{l}-2.22^{\star \star \star} \\
(3.46)\end{array}$ & $\begin{array}{l}-.84 \\
(1.61)\end{array}$ & $\begin{array}{l}.11 \\
(.21)\end{array}$ & $\begin{array}{l}.42 \\
(.67)\end{array}$ & $\begin{array}{l}-.40 \\
(.57)\end{array}$ & $\begin{array}{r}1.24^{\star} \\
(1.84)\end{array}$ & .206 & 4459 & 2.2 & 6.5 & 1.0 \\
\hline 1984 & $\begin{array}{l}-2.31 * \star \star \\
(3.40)\end{array}$ & $\begin{array}{l}.16 \\
(.29)\end{array}$ & $\begin{array}{c}-.83 \\
(1.45)\end{array}$ & $\begin{array}{c}.17 \\
(.25)\end{array}$ & $\begin{array}{l}-.55 \\
(.74)\end{array}$ & $\begin{array}{c}.15 \\
(.22)\end{array}$ & .229 & 4523 & 0.1 & 2.1 & .3 \\
\hline 1983 & $\begin{array}{l}-1.00 \\
(1.35)\end{array}$ & $\begin{array}{l}-1.25^{\star \star} \\
(2.02)\end{array}$ & $\begin{array}{c}-.96 \\
(1.52)\end{array}$ & $\begin{array}{c}-.89 \\
(1.23)\end{array}$ & $\begin{array}{c}-.92 \\
(1.13)\end{array}$ & $\begin{array}{l}.26 \\
(.33)\end{array}$ & .212 & 4888 & 2.5 & .1 & .2 \\
\hline 1982 & $\begin{array}{l}-2.41^{\star \star \star} \\
(3.03)\end{array}$ & $\begin{array}{l}-2.07 * \star \star \\
(3.19)\end{array}$ & $\begin{array}{c}-.70 \\
(1.06)\end{array}$ & $\begin{array}{l}-2.08^{\star \star \star} \\
(2.76)\end{array}$ & $\begin{array}{c}.20 \\
(.23)\end{array}$ & $\begin{array}{c}1.13 \\
(1.38)\end{array}$ & .200 & 4835 & .5 & 1.0 & 0.0 \\
\hline 1981 & $\begin{array}{l}-2.38 \star \star \star \\
(3.10)\end{array}$ & $\begin{array}{l}-1.32^{\star \star} \\
(2.07)\end{array}$ & $\begin{array}{c}-.96 \\
(1.47)\end{array}$ & $\begin{array}{l}-1.20 \\
(1.64)\end{array}$ & $\begin{array}{l}-.25 \\
(.29)\end{array}$ & $\begin{array}{r}1.95^{\star} \\
(1.82)\end{array}$ & .180 & 4761 & 0.0 & 2.2 & .5 \\
\hline 1980 & $\begin{array}{l}-1.52^{\star} \\
(1.84)\end{array}$ & $\begin{array}{l}-1.68 \star \star \\
(2.43)\end{array}$ & $\begin{array}{l}-1.62^{\star \star} \\
(2.31)\end{array}$ & $\begin{array}{l}-1.59 \star \star \\
(2.00)\end{array}$ & $\begin{array}{r}1.69 * \\
(1.86)\end{array}$ & $\begin{array}{l}.00 \\
(.00)\end{array}$ & .163 & 4305 & 0.0 & .9 & 1.4 \\
\hline 1979 & $\begin{array}{l}-1.77 \star \star \\
(2.07)\end{array}$ & $\begin{array}{l}-1.08 \\
(1.48)\end{array}$ & $\begin{array}{l}-2.24^{\star \star \star} \\
(3.05)\end{array}$ & $\begin{array}{l}-.50 \\
(.62)\end{array}$ & $\begin{array}{l}2.25^{\star \star} \\
(2.36)\end{array}$ & $\begin{array}{l}-.46 \\
(.50)\end{array}$ & .177 & 3057 & 8.4 & 3.0 & 5.6 \\
\hline Female & & & & & & & & & & & \\
\hline 1985 & $\begin{array}{l}.67 \\
(.75)\end{array}$ & $\begin{array}{c}-.65 \\
(1.24)\end{array}$ & $\begin{array}{l}.48 \\
(.84)\end{array}$ & $\begin{array}{l}-.52 \\
(.76)\end{array}$ & $\begin{array}{l}-1.74^{\star \star} \\
(2.28)\end{array}$ & $\begin{array}{l}-.32 \\
(.44)\end{array}$ & .203 & 4223 & 8.0 & 3.9 & 6.5 \\
\hline 1984 & $\begin{array}{l}1.43 \\
(1.46)\end{array}$ & $\begin{array}{l}-1.74 * k \star \\
(3.06)\end{array}$ & $\begin{array}{l}.52 \\
(.83)\end{array}$ & $\begin{array}{l}-.68 \\
(.91)\end{array}$ & $\begin{array}{l}-1.55^{\star} \\
(1.87)\end{array}$ & $\begin{array}{l}-.71 \\
(.91)\end{array}$ & .216 & 4285 & 8.8 & 5.9 & 7.0 \\
\hline 1983 & $\begin{array}{l}1.61^{\star} \\
(1.67)\end{array}$ & $\begin{array}{c}-.67 \\
(1.26)\end{array}$ & $\begin{array}{c}-.79 \\
(1.24)\end{array}$ & $\begin{array}{c}-.86 \\
(1.14)\end{array}$ & $\begin{array}{l}-2.67 * * * \\
(3.15)\end{array}$ & $\begin{array}{l}-.04 \\
(.05)\end{array}$ & .216 & 4446 & 12.7 & 8.3 & 4.4 \\
\hline 1982 & $\begin{array}{l}3.28^{\star \star \star} \\
(3.21)\end{array}$ & $\begin{array}{l}-.23 \\
(.38)\end{array}$ & $\begin{array}{l}-1.22^{\star} \\
(1.82)\end{array}$ & $\begin{array}{l}-1.51^{\star} \\
(1.92)\end{array}$ & $\begin{array}{l}-2.97 \star \star \star \\
(3.31)\end{array}$ & $\begin{array}{l}-.82 \\
(.97)\end{array}$ & .223 & 4442 & 25.6 & 20.6 & 8.6 \\
\hline 1981 & $\begin{array}{l}3.66^{\star \star \star} \\
(3.58)\end{array}$ & $\begin{array}{l}-1.18^{\star} \\
(1.93)\end{array}$ & $\begin{array}{l}-1.05 \\
(1.59)\end{array}$ & $\begin{array}{c}-.99 \\
(1.27)\end{array}$ & $\begin{array}{l}-3.33 * \star \star \\
(3.72)\end{array}$ & $\begin{array}{c}.13 \\
(.16)\end{array}$ & .209 & 4380 & 16.1 & 17.3 & 5.1 \\
\hline 1980 & $\begin{array}{l}2.99 \star \star \star \\
(2.71)\end{array}$ & $\begin{array}{l}-1.62^{\star \star} \\
(2.48)\end{array}$ & $\begin{array}{l}-.20 \\
(.28)\end{array}$ & $\begin{array}{l}-1.74^{\star \star} \\
(2.10)\end{array}$ & $\begin{array}{l}-1.90^{\star} \\
(1.98)\end{array}$ & $\begin{array}{l}-.34 \\
(.38)\end{array}$ & .181 & 3982 & 12.7 & 11.9 & 6.4 \\
\hline 1979 & $\begin{array}{l}2.74^{\star \star} \\
(2.26)\end{array}$ & $\begin{array}{l}-1.43^{\star \star} \\
(2.04)\end{array}$ & $\begin{array}{l}-1.94 \star \star \\
(2.44)\end{array}$ & $\begin{array}{l}-1.53^{*} \\
(1.68)\end{array}$ & $\begin{array}{l}-1.88 * \\
(1.75)\end{array}$ & .23 & .168 & 2914 & 6.7 & 7.0 & .6 \\
\hline
\end{tabular}


Table 5

The Effect of Competencies on Labor Market Outcones : 1981-1985

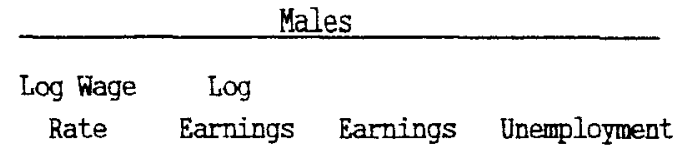

Eemales

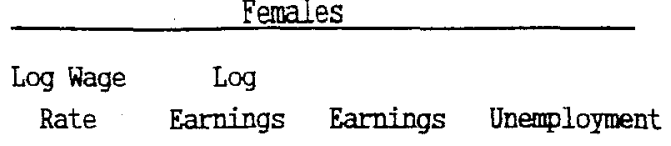

Main Effects

Technical

$\begin{array}{llll}.044 * \star \star & .087 \star \star \star & 1333 * \star \star & -2.17 * \star \star \\ (3.37) & (4.66) & (7.33) & (3.99)\end{array}$

Clerical Speed

$\begin{array}{cccc}-.004 & .017 & 359 * \star \star & -1.08 * \star \star \\ (.36) & (1.26) & (2.63) & (2.86)\end{array}$

Comp. Speed

$.062 \star \star \star \quad .095 * \star \star \quad 1088 * \star \star \quad-.40$

$(5.54) \quad(6.01) \quad(7.11) \quad(.89)$

Math

$-.005 \quad-.015$

$-86$

$-1.24 \star \star$

$(.43) \quad(.88)$

(.50)

(2.56)

Verbal

$-.016 \quad-.015$

$-438 * \star$

.02

(1.21) (.79)

(2.35)

(.04)

Science

$\begin{array}{cccc}-.003 & -.009 & -66 & 1.02 \\ (.22) & (.51) & (.37) & (2.04)\end{array}$

1.02

$$
\begin{gathered}
.017 \\
(1.04)
\end{gathered}
$$$$
-.007
$$

$-105$

.58

.010

(.24)

(.69)

(.80)

(1.20)

$(2.04) \quad(2.28)$

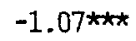

$(2.04) \quad(2.28) \quad$ (3.06)

$\begin{array}{cccl}.031 * \star \star & .026 & 442^{\star \star \star} & -.93 * \star \\ (3.01) & (1.42) & (4.72) & (2.08) \\ .025 \star \star & .074 * \star \star & 663 \star \star \star & -1.15 \star \star \\ (2.19) & (3.79) & (5.91) & (2.36) \\ .006 & .044 * & 353 * \star \star & -2.20 \star \star \star \\ (.45) & (1.92) & (2.97) & (4.07) \\ -.012 & -.030 & -49 & -.21 \\ (1.01) & (1.41) & (.43) & (.41)\end{array}$

Age Times

Technical

$$
\begin{array}{lccc}
.0067 * \star & .0007 & 76 & -.08 \\
(2.10) & (.13) & (1.40) & (.48)
\end{array}
$$

.003

.0012

(.14)

$-4$

$(.09)$

.03

.0026

$.0097 *$

$95 * * *$

(.14)

Comp. Speed

(2.30)

(.39)

(3.72)

(1.72)

Academic

$\begin{array}{cccc}-.0020 & .0040 & -5 & .49 * \star \\ (.52) & (.60) & (.08) & (2.42)\end{array}$

(1.06)

(1.92)

(3.62)

$.46 * \pi+$

$.0064 \quad-.0049 \quad-93 * *$

$(3.66)$

(1.56)

(.58)

(2.09)

.18

Student Times

Technical

$\begin{array}{llll}.012 & .141 * * * & -496 & .60 \\ (.64) & (3.50) & (1.43) & (.46)\end{array}$

$-.036$

.050

347

(.88) (1.13)

$3.42 \star \star$

(1.63)

.07

$(.07)$

Comp. Speed

$-.006$

$.000-607 * \star$

$-.005$

.014

$-183$

(.35)

(.40)

(1.00)

$-.024 \quad-.236 \star \star \star *-2256 * \star \star \quad-.95$

(1.11) (4.19) (7.89)

(.62)

.65
$(.43)$

Years of College

times Academic

$\begin{array}{cccc}.0069 & -.0129 & -169 \star \star & .17 \\ (1.29) & (1.60) & (2.11) & (.73)\end{array}$

$.0156 * * \star *$

.014

(2.93)

(1.59)

(5.13)

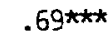

(3.03)

$\mathrm{R}^{2}$

$.130 \quad .222$

.195

.117

.127

.208

.234

.116

Number of Obs. $\quad 2155 \quad 3054 \quad 4122 \quad 3342$

1919

$2240 \quad 4532$

2867

E Test

Acad. = Zero

2.0

2.5

3.0

0.1

1.2

$8.6 \quad 37.8$

23.1

Acad. = Technical

6.1

10.1

20.3

2.9

0.0

3.2

14.4

9.5

Acad. = Compute

13.5

15.8

21.2

0.0

2.5

6.4

7.1 
Table 6

The Effect of Competencies on Labor varket outcomes

(No Controls for Education)

Males

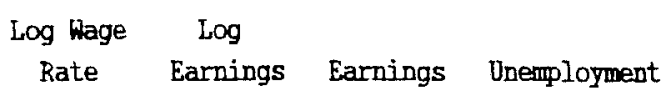

Main Effects

Technical

$\begin{array}{llll}.043 * \star \star & .080 * \star \star & 1233 * \star \star & -1.99 \star \star \star \\ (3.33) & (4.24) & (6.79) & (3.66)\end{array}$

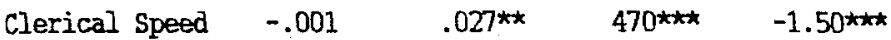

$\begin{array}{llll}(.07) \quad(1.99) & (3.41) \quad(3.96)\end{array}$

Comp. Speed

$\begin{array}{cccc}.065 * * \star & .105 * \star \star & 1249 * \star * & .68 \\ (5.87) & (6.61) & (8.16) & (1.52)\end{array}$

Math

$\begin{array}{llll}.006 & .003 & 269 & -1.75 * \star *\end{array}$

$(.48) \quad(.20)$

(1.64)

(3.79)

Verbal

$\begin{array}{llll}-.013 & .000 & -174 & -.45 \\ (1.01) & (.03) & (.35) & (.86)\end{array}$

Science

$\begin{array}{llcc}.005 & .005 & 75 & .60 \\ (.40) & (.28) & (.42) & (1.20)\end{array}$

Age Times

Technical

$$
\begin{array}{cccc}
.0032 & -.0056 & 11 & .03 \\
(1.05) & (1.04) & (.20) & (.20)
\end{array}
$$

Comp. Speed

$$
.0055^{\star \star} \quad .00
$$$$
\text { (2.24) (.65) }
$$

$179 * * *$

.20

Acadenic

$\begin{array}{llrr}.0046 & .0135 * * & 112 * & .28 \\ (1.27) & (2.17) & (1.80) & (1.49)\end{array}$

Student Times

Technical$$
.010
$$$$
\text { (.57) }
$$

$.138^{* \star *}$

(3.40)

$-570$

(1.64)

$(.64)$

Comp. Speed

$\begin{array}{llll}-.007 & .000 & -627 \star \star & .10 \\ (.48) & (.01) & (2.26) & (.09) \\ -.026 & -.252^{\star \star \star} & -1243 \star \star \star & 1.00 \\ (1.28) & (5.37) & (3.07) & (.66)\end{array}$

$R^{2}$

.125

.215

.187

.110

Number of Obs.

2155

3054

4122

3342

F Test

Acad. = Zero

0.0

0.1

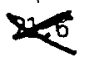

5.5

Acad. = Technical

2.9

3.3

8.0

0.1

Acad. = Compute

8.9

8.4

11.5

0.9
Females

$\begin{array}{ccc}\text { Log Wage } & \text { Log } & \\ \text { Rate } & \text { Earnings } & \text { Earnings Unemployment }\end{array}$

$\begin{array}{cccc}.013 & -.016 & -248 & .88 \\ (.78) & (.58) & (1.60) & (1.21) \\ .015 \star & .035 * \star & 213^{\star \star \star} & -1.25 \star \star \star \\ (1.72) & (2.44) & (2.63) & (3.58) \\ .031 \star \star \star & .030 & 437 \star \star \star & -1.12 \star \star \\ (3.05) & (1.61) & (4.99) & (2.50) \\ .046 \star \star \star & .103 & 1210 \star \star \star & -1.20 \star \star \star \\ (4.30) & (5.64) & (11.38) & (2.61) \\ .008 & .053 & 404 \star \star \star & -2.88 \star \star \star \\ (.66) & (2.33) & (3.42) & (5.41) \\ .000 & -.014 & 178 & -.14 \\ (.03) & (.67) & (1.56) & (.27)\end{array}$

$\begin{array}{lccc}.0017 & -.001 & -47 & .06 \\ (.40) & (.10) & (2.18) & (.27) \\ .0033 & .0109 \star \star & 114 \star \star \star & .41 * \pi \star \\ (1.36) & (2.16) & (4.33) & (3.26) \\ .0147 \star \star \star & .0048 & 89 \star \star & .18 \\ (3.76) & (.61) & (2.08) & (.92)\end{array}$

$\begin{array}{llrr}-.036 & .056 & 338 & 3.14^{\star} \\ (1.61) & (.99) & (1.09) & (1.95)\end{array}$

$\begin{array}{llll}-.006 & .009 & -186 & .44\end{array}$

$\begin{array}{llll}(.43) & (.26) \quad(1.01) \quad(.45)\end{array}$

$\begin{array}{llll}-.018 & -.239 & -2011 * \star \star & .10\end{array}$

$\begin{array}{llll}(.85) & (4.29) \quad(7.05) & (.07)\end{array}$

$\begin{array}{llll}.120 & .204 & .221 & .110 \\ 1919 & 2240 & 4532 & 2867\end{array}$

$\begin{array}{rrrr}12.1 & 25.3 & 143.6 & 35.6 \\ 1.2 & 9.3 & 53.1 & 14.9 \\ 2.1 & 8.7 & 42.2 & 10.3\end{array}$


Table 7

Cognitive Determinants of Success

in Marine Training Programs

Mechanical Auto \& Shop

Clerical Computational

Math Math

Comprehension Knowledge Electronics

Speed

Speed

Reasoning Knowledge

Verbal

Science Spatial $\mathrm{R}^{2}$

Sims \& Hiatt

ASVAB 6/7

(23061)

A11 Occupations

$.043^{\star \star \star}$

$.098 * \star * *$

$.047 * \star \star$
$(5.78)$

$\frac{.013^{* \star}}{(2.29)}$

$.060 * \star \star$

$\left(116^{\star * *}\right.$

$.205 * \star * *$

$.086 * \star \star$

$.089 * * *$

(10.68) (5.89)
Maier \& Truss

ASVAB 8/9/10

Electronics

Repair (4103)

Mechanical

Maintenance

(5841)

operators, Food

(1897)

Clerical

(5231)

Combat

(8191)

Field Artillery

(1062)

\begin{tabular}{|c|c|c|c|c|c|c|c|c|c|c|}
\hline $\begin{array}{l}.055^{\star \star *} \\
(2.73)\end{array}$ & $\begin{array}{c}.027 \\
(1.40)\end{array}$ & $\begin{array}{l}.102^{\star \star \star} \\
(4.81)\end{array}$ & $\begin{array}{l}.009 \\
(.69)\end{array}$ & $\begin{array}{l}.062^{\star \star \star} \\
(3.44)\end{array}$ & $\begin{array}{l}.151^{\star \star \star} \\
(6.41)\end{array}$ & $\begin{array}{l}.256^{\star \star \star} \\
(11.91)\end{array}$ & $\begin{array}{l}.031 \\
(1.40)\end{array}$ & $\begin{array}{l}.130 * \star \star \\
(5.73)\end{array}$ & -- & .492 \\
\hline $\begin{array}{l}.058^{\star \star *} \\
(3.29)\end{array}$ & $\begin{array}{c}.253^{\star \star \star} \\
(15.02)\end{array}$ & $\begin{array}{l}.094^{* * \star} \\
(5.02)\end{array}$ & $\begin{array}{l}.063^{* \star *} \\
(4.44)\end{array}$ & $\begin{array}{l}.014 \\
(.87)\end{array}$ & $\begin{array}{l}.086 * \star \star \\
(4.16)\end{array}$ & $\begin{array}{l}.135^{\star \star \star} \\
(7.14)\end{array}$ & $\begin{array}{l}.120 * \star \star \\
(6.27)\end{array}$ & $\begin{array}{l}.005 \\
(.27)\end{array}$ & --- & .444 \\
\hline $\begin{array}{l}.079 * \star \star \\
(2.72)\end{array}$ & $\begin{array}{c}.063^{\star \star} \\
(2.27)\end{array}$ & $\begin{array}{l}.018 \\
(.57)\end{array}$ & $\begin{array}{l}.086 * \star \star \\
(3.66)\end{array}$ & $\begin{array}{l}.022 \\
(.82)\end{array}$ & $\begin{array}{l}.137^{\star * *} \\
(4.02)\end{array}$ & $\begin{array}{l}.199 * * \star \\
(6.41)\end{array}$ & $\begin{array}{l}.164 \star \star \star \\
(5.20)\end{array}$ & $\begin{array}{l}.093 \star \star \star \\
(2.84)\end{array}$ & - & .490 \\
\hline $\begin{array}{l}.014 \\
(.74)\end{array}$ & $\begin{array}{l}-.022 \\
(1.22)\end{array}$ & $\begin{array}{c}.026 \\
(1.33)\end{array}$ & $\begin{array}{l}.136^{\star \star \star} \\
(9.03)\end{array}$ & $\begin{array}{l}.037 * \star \\
(2.26)\end{array}$ & $\begin{array}{l}.125^{\star * \star} \\
(5.70)\end{array}$ & $\begin{array}{c}.259 * \pi \star \\
(13.02)\end{array}$ & $\begin{array}{l}.206^{\star \star \star} \\
(10.14)\end{array}$ & $\begin{array}{r}-.101 \\
(.47)\end{array}$ & -- & .443 \\
\hline $\begin{array}{l}.087^{\star \star \star} \\
(4.98)\end{array}$ & $\begin{array}{l}.078^{\star \star \star} \\
(4.68)\end{array}$ & $\begin{array}{c}.020 \\
(1.09)\end{array}$ & $\begin{array}{r}.027 * \\
(1.95)\end{array}$ & $\begin{array}{l}.056 * \star * \\
(3.62)\end{array}$ & $\begin{array}{c}.069 * * \\
(3.40)\end{array}$ & $\begin{array}{l}.143^{\star \star \star} \\
(7.71)\end{array}$ & $\begin{array}{l}.073 * x * \\
(3.88)\end{array}$ & $\begin{array}{l}.061^{\star \star \star} \\
(3.12)\end{array}$ & $-\cdots$ & .251 \\
\hline $\begin{array}{c}.055 \\
(1.34)\end{array}$ & $\begin{array}{l}.237 * \star \star \\
(6.01)\end{array}$ & $\begin{array}{r}-.009 \\
(.21)\end{array}$ & $\begin{array}{l}.178 * \star \star \\
(5.36)\end{array}$ & $\begin{array}{c}.060 \\
(1.64)\end{array}$ & $\begin{array}{l}.148^{\star \star \star} \\
(3.07)\end{array}$ & $\begin{array}{l}.138 * \star \star \\
(3.13)\end{array}$ & $\begin{array}{r}-.011 \\
(.24)\end{array}$ & $\begin{array}{l}.065 \\
(1.41)\end{array}$ & -- & .448 \\
\hline
\end{tabular}


Table 8

Effect of Competencies on Job Performance (SQT)

\begin{tabular}{|c|c|c|c|c|c|c|c|c|c|c|c|}
\hline & $\begin{array}{l}\text { Mechanical } \\
\text { Comprehension }\end{array}$ & $\begin{array}{l}\text { Auto } \\
\text { Info }\end{array}$ & $\begin{array}{l}\text { Shop } \\
\text { Info }\end{array}$ & $\begin{array}{l}\text { Electr. } \\
\text { Info }\end{array}$ & $\begin{array}{l}\text { Attention } \\
\text { to } \\
\text { Detail }\end{array}$ & $\begin{array}{l}\text { Comp. } \\
\text { Speed }\end{array}$ & $\begin{array}{l}\text { Word } \\
\text { Know }\end{array}$ & $\begin{array}{l}\text { Arith } \\
\text { Reasoning }\end{array}$ & $\begin{array}{l}\text { Math } \\
\text { Know }\end{array}$ & Science & $\mathrm{R}^{2}$ \\
\hline $\begin{array}{l}\text { Skilled Technical } \\
\text { (1324) }\end{array}$ & $\begin{array}{l}.092^{\star \star \star} \\
(3.07)\end{array}$ & $\begin{array}{l}.017 \\
(.58)\end{array}$ & $\begin{array}{l}.132 \star * \star \\
(4.28)\end{array}$ & $\begin{array}{l}.174^{\star \star \star} \\
(5.09)\end{array}$ & $\begin{array}{c}.024 \\
(1.12)\end{array}$ & $\begin{array}{c}.031 \\
(1.17)\end{array}$ & $\begin{array}{l}.215^{\star \star \star} \\
(6.77)\end{array}$ & $\begin{array}{l}.062^{\star \star} \\
(1.96)\end{array}$ & $\begin{array}{l}.121^{\star \star \star} \\
(3.76)\end{array}$ & $\begin{array}{r}.057^{\star} \\
(1.83)\end{array}$ & .548 \\
\hline $\begin{array}{l}\text { Skilled Electronic } \\
\text { (349) }\end{array}$ & $\begin{array}{c}.086 \\
(1.30)\end{array}$ & $\begin{array}{c}.098 \\
(1.49)\end{array}$ & $\begin{array}{l}.246^{\star \star \star} \\
(3.64)\end{array}$ & $\begin{array}{l}.045 \\
(.60)\end{array}$ & $\begin{array}{c}.084 \\
(1.81)\end{array}$ & $\begin{array}{r}-.013 \\
(.22)\end{array}$ & $\begin{array}{r}-.004 \\
(.06)\end{array}$ & $\begin{array}{r}-.021 \\
(.30)\end{array}$ & $\begin{array}{l}.261 * \star \star \\
(3.67)\end{array}$ & $\begin{array}{c}.072 \\
(1.05)\end{array}$ & .426 \\
\hline General (Const) & & & & & & & & & & & \\
\hline $\begin{array}{l}\text { Maintenance } \\
\qquad(879)\end{array}$ & $\begin{array}{r}-.004 \\
(.11)\end{array}$ & $\begin{array}{l}.082^{\star \star} \\
(2.34)\end{array}$ & $\begin{array}{l}.117^{\star \star \star} \\
(3.25)\end{array}$ & $\begin{array}{l}.121^{\star \star \star} \\
(3.05)\end{array}$ & $\begin{array}{c}.043^{*} \\
(1.76)\end{array}$ & $\begin{array}{l}.068 * \star \star \\
(2.19)\end{array}$ & $\begin{array}{r}.066^{\star} \\
(1.80)\end{array}$ & $\begin{array}{l}-.101^{\star \star \star} \\
(2.73)\end{array}$ & $\begin{array}{l}.441 * * * \\
(11.70)\end{array}$ & $\begin{array}{l}.134 * \star \star \\
(3.67)\end{array}$ & .592 \\
\hline \multicolumn{12}{|l|}{ Mechanical } \\
\hline $\begin{array}{c}\text { Maintenance } \\
\text { (131) }\end{array}$ & $\begin{array}{l}.042 \\
(.38)\end{array}$ & $\begin{array}{l}.314^{\star \star \star} \\
(2.88)\end{array}$ & $\begin{array}{c}.206^{\star} \\
(1.84)\end{array}$ & $\begin{array}{r}-.089 \\
(.71)\end{array}$ & $\begin{array}{l}.055 \\
(.72)\end{array}$ & $\begin{array}{l}.235 \star \star \\
(2.43)\end{array}$ & $\begin{array}{r}-.004 \\
(.03)\end{array}$ & $\begin{array}{r}-.068 \\
(.59)\end{array}$ & $\begin{array}{l}.061 \\
(.52)\end{array}$ & $\begin{array}{c}.096 \\
(.85) \\
.\end{array}$ & .412 \\
\hline $\begin{array}{r}\text { Clerical } \\
(830)\end{array}$ & $\begin{array}{c}-.058 \\
(-1.59)\end{array}$ & $\begin{array}{l}.087 * \star \star \\
(2.05)\end{array}$ & $\begin{array}{l}-.030 \\
(-.69)\end{array}$ & $\begin{array}{c}.065 \\
(1.33)\end{array}$ & $\begin{array}{l}.015 \\
(.50)\end{array}$ & $\begin{array}{l}.085^{\star \star} \\
(2.24)\end{array}$ & $\begin{array}{l}.118^{\star \star \star} \\
(2.61)\end{array}$ & $\begin{array}{l}.241 \star \star \star \\
(5.33)\end{array}$ & $\begin{array}{l}.206 \star \star \star \\
(4.46)\end{array}$ & $\begin{array}{c}.064 \\
(1.44)\end{array}$ & .425 \\
\hline $\begin{array}{l}\text { Operators \& Food } \\
\text { (814) }\end{array}$ & $\begin{array}{r}.109 * \\
(2.50)\end{array}$ & $\begin{array}{l}.179 * * * \\
(4.11)\end{array}$ & $\begin{array}{c}.062 \\
(1.39)\end{array}$ & $\begin{array}{l}.100^{\star \star} \\
(2.02)\end{array}$ & $\begin{array}{c}.050 \\
(1.62)\end{array}$ & $\begin{array}{r}-.037 \\
(.96)\end{array}$ & $\begin{array}{c}.061 \\
(1.33)\end{array}$ & $\begin{array}{r}.114^{\star} \\
(2.47)\end{array}$ & $\begin{array}{l}.106^{\star \star} \\
(2.25)\end{array}$ & $\begin{array}{r}.076^{\star} \\
(1.66)\end{array}$ & .414 \\
\hline $\begin{array}{l}\text { Combat } \\
\qquad(5403)\end{array}$ & $\begin{array}{l}.147 \star \star \star \\
(8.28)\end{array}$ & $\begin{array}{l}.060^{\star \star \star} \\
(3.38)\end{array}$ & $\begin{array}{l}.080 \star \star \star \\
(4.42)\end{array}$ & $\begin{array}{l}.058^{\star \star \star} \\
(2.86)\end{array}$ & $\begin{array}{l}.048^{\star \star \star} \\
(3.82)\end{array}$ & $\begin{array}{l}.035 * \star \\
(2.23)\end{array}$ & $\begin{array}{l}.069 * \star \star \\
(3.71)\end{array}$ & $\begin{array}{l}.070^{\star \star \star \star} \\
(3.74)\end{array}$ & $\begin{array}{l}.139 * \star \star \\
(7.29)\end{array}$ & $\begin{array}{l}.070^{\star \star \star} \\
(3.82)\end{array}$ & .358 \\
\hline $\begin{array}{l}\text { Field Artillery } \\
\text { (534) }\end{array}$ & $\begin{array}{c}.059 \\
(1.10)\end{array}$ & $\begin{array}{l}.047 \\
(.89)\end{array}$ & $\begin{array}{l}.030 \\
(.56)\end{array}$ & $\begin{array}{l}.134^{\star \star} \\
(2.21)\end{array}$ & $\begin{array}{l}.088^{\star \star} \\
(2.33)\end{array}$ & $\begin{array}{r}-.009 \\
(.19)\end{array}$ & $\begin{array}{l}.000 \\
(.01)\end{array}$ & $\begin{array}{l}.186^{\star \star \star} \\
(3.28)\end{array}$ & $\begin{array}{l}.230 * \star \star \\
(3.99)\end{array}$ & $\begin{array}{c}.061 \\
(1.10)\end{array}$ & .422 \\
\hline
\end{tabular}

Re-Analysis of Maier \& Grafton's (1981) data on the ability of ASVAB 6/7 to predict Skill Qualification Test (SQT) scores. The correlation matrix was corrected for restriction of range by Maier \& Grafton. 
Table 9

Effect of ASVAB Subtests on Different

Attitudes on work samples and job knowledge tests

for Marine Riflemen

\section{Mechanical Auto/Shop}

Electronics

Clerical Computational

Speed

Math

Math

Word

Science

$\mathrm{R}^{2}$

Hands-On

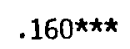

(3.26)

$.295^{\star \star \star *}$

(6.78)

.093

(1.92)

$.099 \star \pi \quad-.024$

(2.18)

(.45)

$.200 \star \star \star \quad .015$

(3.45)

(.27)

$-.086$

(1.25)

$.120 * \star$

$(2.21)$

Job Knowledge

$.102 * \star \quad .141 * * \star$

(2.14)

(3.33)

$.111^{\star \star}$

$.151 * \star *$
$(3.42)$

.115 **

(2.20)

.212
$(3.76)$

.129

(2.40)

.082

(1.23)

$.186 \star \star \star \quad .319$ 
Table 10

ASVAB SUBTESTS WHICH ARE THE BEST PREDICTORS OF CORE TECHNICAL PROFICIENCY by Military Occupational Specialty Cluster

Subtest

Electronics

Repair (123)

Skilled Tech. Mechanical Comp. (1329)

Mechanical

Maintenance

(716)

General Auto-Shop Know.

Maintenance

(272)

Operators/Food Auto-Shop Know.
(1215)

Surveillance \&

Communication

(289)

Clerical

(1210)

Combat

(1429)

Field

Artillery

(464)

Source: Summarized from Table 2 of Wise, HcHenry, Rossmeissl and oppler, 1987. Based on an analysis of the ability of ASVAB subtests to predict Core Technical Proficiency ratings after the recruit has been in the US Army for 2 or 3 years. Core Technical Proficiency ratings are about 50 percent based on hands-on work sample tests and 50 percent based on paper and pencil job knowledge exams. The subtests listed in the table are the 3 or 4 subtests which in combination maximized the $R^{2}$ of the model predicting Core Technical Proficiency.
Arith Reasoning Math Knowledge

Math Knowledge or Arith Reason.

Arith Reasoning Math Knowledge

Math Knowledge

Science

Science

Verbal

Verbal

Verbal
Auto-Shop Know. Compute-Speed Verbal

Science

Science Verbal Mechanical Comp. Mechanical Comp.

Science

Mechanical Comp.

Math Knowledge

Verbal

Science
Science 
Table 11

$$
\begin{gathered}
\text { Effect of ASVAB Composite } \\
\text { on other Dimensions of Job Performance }
\end{gathered}
$$

\begin{tabular}{|c|c|c|c|c|c|}
\hline Proficiency & .26 & .03 & .20 & .10 & .461 \\
\hline \multicolumn{6}{|l|}{ Effort and } \\
\hline Leadership (resid) & .21 & .07 & .08 & .03 & .280 \\
\hline \multicolumn{6}{|l|}{ Effort and } \\
\hline Leadership (raw) & .21 & .09 & .03 & -.07 & .206 \\
\hline Personal Discipline & .06 & .04 & .07 & -.03 & .10 \\
\hline
\end{tabular}

Technical Speed Quantitative Verbal $\mathrm{R}^{2}$

Source from John Campbell, 1986, Table 10. Standardized Coefficients from an Analysis of Project A Data on Performance in the Military. 
APPENDIX A

Sample Regression Used in

Tables 1-5 
VARIABLE: LWGBE

\begin{tabular}{|c|c|c|c|c|c|}
\hline & & $\begin{array}{l}\text { ANAI } \\
\text { Table }\end{array}$ & $\begin{array}{l}\text { SIS OF VARIA } \\
\text { 1: Used in } \mathrm{Ta}\end{array}$ & & \\
\hline SOURCE & DF & $\begin{array}{l}\text { SUM OF } \\
\text { SQUARES }\end{array}$ & $\begin{array}{r}\text { MEAN } \\
\text { SQUARE }\end{array}$ & F VALUE & PROB $>F$ \\
\hline MODEL & 28 & 285.41524 & 10.19340134 & 55.767 & 0.0001 \\
\hline ERROR & 4244 & 775.74026 & 0.18278517 & & \\
\hline C TOTAL & 4272 & 1051.15550 & & & \\
\hline ROOT & MSE & 0.4275338 & R-SQUARE & 0.2690 & \\
\hline $\begin{array}{l}\text { DEP } \\
\text { C.V. }\end{array}$ & MEAN & $\begin{array}{l}6.479785 \\
6.597963\end{array}$ & $A D J \quad R-S Q$ & 0.2541 & \\
\hline
\end{tabular}

PARAMETER ESTIMATES

\begin{tabular}{|c|c|c|}
\hline IR I ABLE & DF & $\begin{array}{l}\text { PARAMETER } \\
\text { EST I MATE }\end{array}$ \\
\hline STERCEP & 1 & 6.15948794 \\
\hline 1ATH & 1 & -0.005502410 \\
\hline VERBAL & 1 & -0.02125655 \\
\hline $\mathrm{SCI}$ & 1 & -0.00816851 \\
\hline JCT & 1 & 0.0795538 \\
\hline NLBE & 1 & -0.0429243 \\
\hline ? T 86 & 1 & 0.1151248 \\
\hline 5G86 & 1 & 0.02565 \\
\hline$\equiv 86$ & 1 & 0.12259 \\
\hline 386 & 1 & 0.028495 \\
\hline 586 & 1 & 0.104858 \\
\hline ISP & 1 & 0.0384008 \\
\hline ZLER & 1 & $0.0054507 \varepsilon$ \\
\hline ZOMPU & 1 & 0.0635465 \\
\hline HILDBE & 1 & 0.011829 \\
\hline ARBE & 1 & 0.0861860 \\
\hline URB2 & 1 & -0.0486270 \\
\hline SMSABE & 1 & -0.0922022 \\
\hline D86 & 1 & 0.0156157 \\
\hline EDBE & 1 & 0.0319801 \\
\hline DX8E & 1 & -0.0254800 \\
\hline ACE 1 & 1 & 0.0338090 \\
\hline$A C E 2$ & 1 & -0.0573100 \\
\hline GE79 & 1 & -0.00229750 \\
\hline GES8E & 1 & -0.00023185 \\
\hline T86 & 1 & -0.0321615 \\
\hline TT8E & 1 & -0.173254 \\
\hline XPWKE & 1 & $0.001157 \varepsilon$ \\
\hline XPUSBG & 1 & $-2.79958 \mathrm{E}-$ \\
\hline
\end{tabular}

STANDARD

ERROR

0.40052599

0.01292803

0.01430650

0.01364133

0.01302474

0.007825550

0.03598091

0.02218629

0.02117204

0.01795778

0.02088667

0.02278839

0.01057584

0.01104821

0.01748597

0.01776652

0.01816563

0.01623190

0.008062571

0.01002441

0.009126239

0.02017512

0.03252614

0.02931786

0.001553210

0.03305113

0.03298882

0.000229173

4. 11561 E-07
T FOR HO:

PARAMETER $=0$

15.400

$-0.511$

$-1.486$

$-0.599$

6. 108

$-5.485$

3.227

1.202

5.790

1. 587

5.020

1.585

0.511

5.752

0.676

4.851

$-2.677$

$-5.680$

1.937

3.190

$-2.792$

1.675

$-1.762$

$-0.078$

$-0.149$

$-0.973$

$-5.252$

5.052

$-0.680$
$\mathrm{PROB}>\mathrm{iT}$

0.0001

0.6096

0.1374

0.5493

0.0001

0.0001

0.0013

0.2295

0.0001

0.1126

0.0001

0.0920

0.6091

0.0001

0.4988

0.0001

0.0075

0.0001

0.0528

0.0014

0.0053

0.0939

0.0781

0.9375

0.8813

0.3306

0.0001

0.0001

0.4964

$T:$

NUMERATOR:

3. 16151

DENOMINATOR:

0.182785

$D F:$

$D F: 4244$

F VALUE:

17.2963

PROB >F : 0.0001

$T:$

NUMERATOR: .0899707 DF: 1 F VALUE:

0.4922

DENOMINATOR:

0.182785

DF: 4244

$P R O B>F$ :

0.4830 
VARIABLE: LWG85

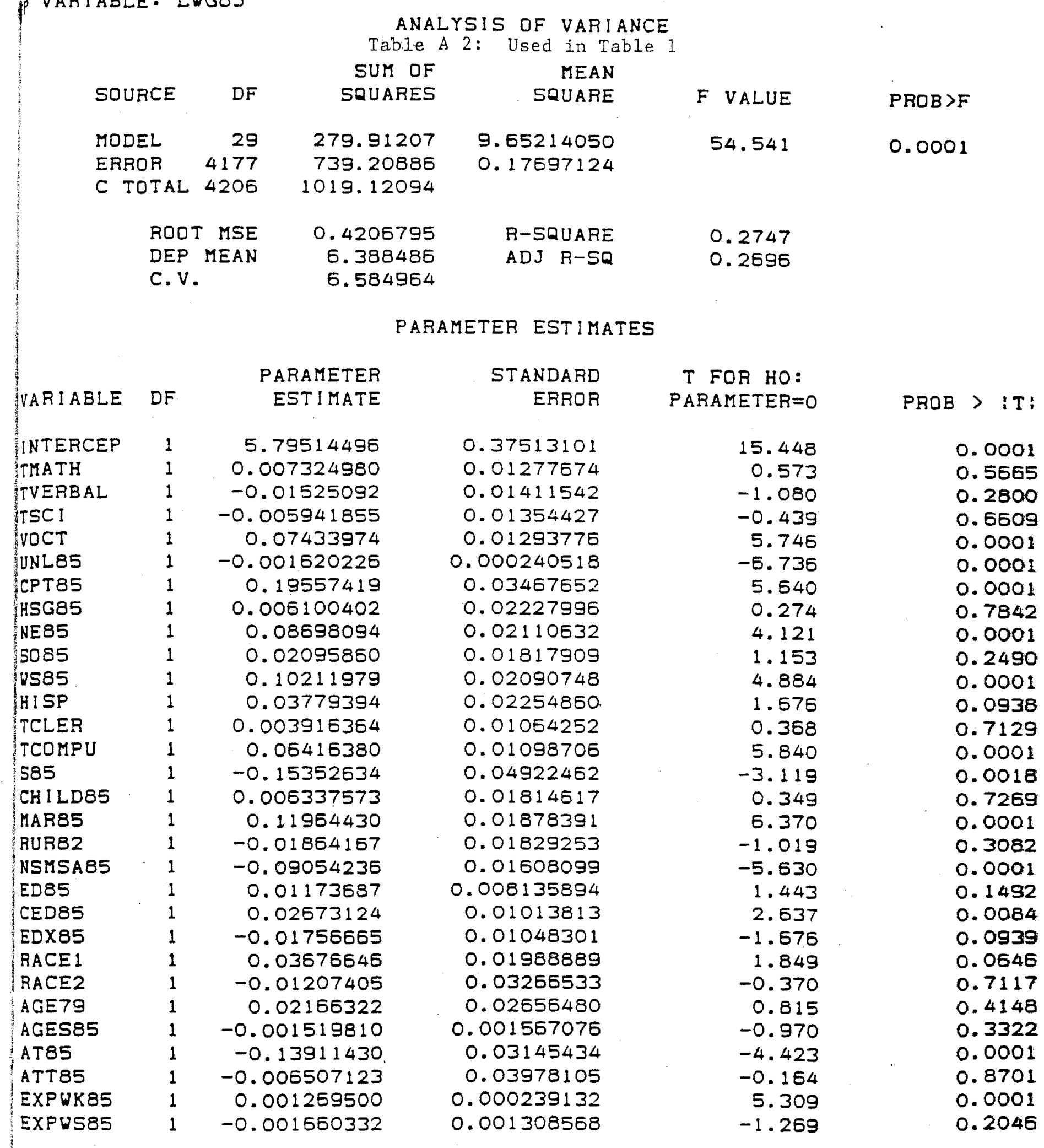

EST:

NUMERATOR:

1.80833

DF: $\quad 1$

F VALUE: $\quad 10.2182$

DENOMINATOR:

0.176971 DF: 4177

$P R O B>F$ :

0.0014

EST :

NUMERATOR:

0.21123

$D F:$

DENOMINATOR:

0.175971

$D F: 4177$

F VALUE:

1.1936

PROB $>F: 0.2747$ 
FEMALE WAGE RATES VOC IS TRADE AND TECH, ACAD IS MT.SCI. ENG

19:06 SUNDAY, JANUARY 1.1989

VARIABLE: LWGBE

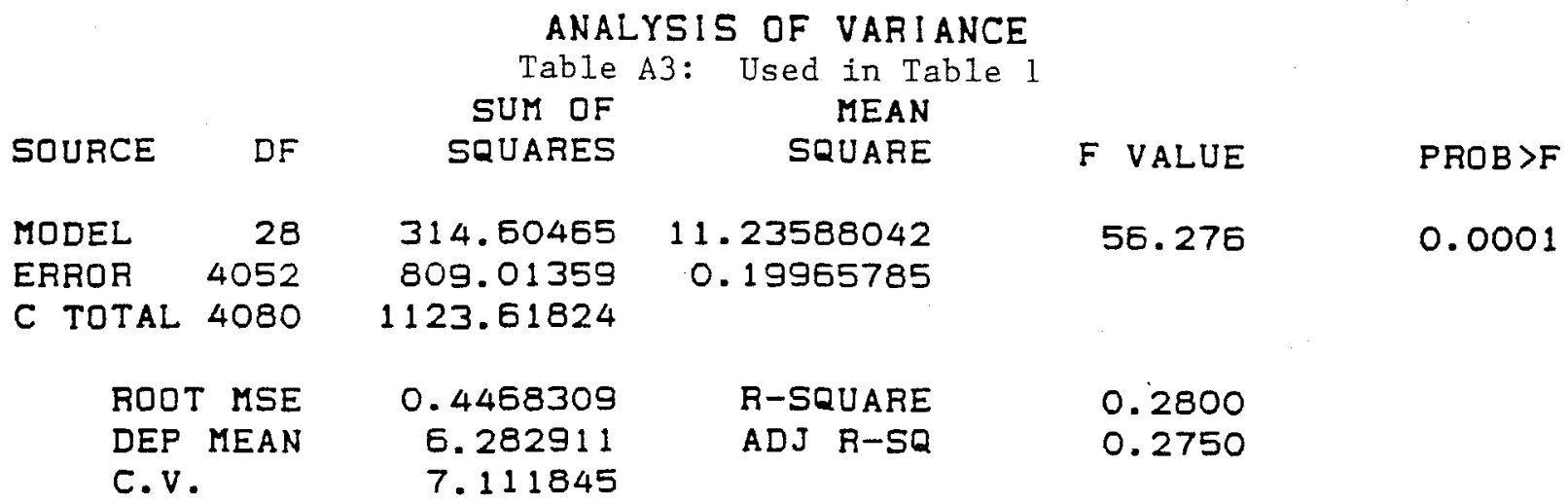

PARAMETER ESTIMATES

\begin{tabular}{|c|c|c|c|c|c|c|c|c|}
\hline RIABLE & DF & $\begin{array}{l}\text { PARAMETER } \\
\text { ESTIMATE }\end{array}$ & \multicolumn{3}{|c|}{$\begin{array}{r}\text { STANDARD } \\
\text { ERROR }\end{array}$} & $\begin{array}{r}T \text { FO } \\
\text { PARAM }\end{array}$ & $\begin{array}{l}\text { IR HO: } \\
\text { IETER }=0\end{array}$ & PRC \\
\hline ITERCEP & 1 & 5.80877312 & \multicolumn{3}{|c|}{0.44498782} & & 13.054 & \\
\hline IATH & 1 & 0.02702377 & \multicolumn{3}{|c|}{0.01394099} & & 1.938 & \\
\hline 'ERBAL & 1 & 0.02729542 & \multicolumn{3}{|c|}{0.01555970} & & 1.754 & \\
\hline ;CI & 1 & 0.01184051 & \multicolumn{3}{|c|}{0.01466895} & & 0.807 & \\
\hline ICT & 1 & 0.005523769 & \multicolumn{3}{|c|}{0.01811500} & & 0.305 & \\
\hline IL86 & 1 & -0.02852499 & \multicolumn{3}{|c|}{0.008250927} & & -3.457 & \\
\hline T & 1 & 0.10935670 & \multicolumn{3}{|c|}{0.03386561} & & 3.229 & \\
\hline ;G86 & 1 & 0.06194364 & \multicolumn{3}{|c|}{0.02644153} & & 2.343 & \\
\hline$: 86$ & 1 & 0.14027139 & \multicolumn{3}{|c|}{0.02275772} & & 6.164 & \\
\hline 386 & 1 & 0.03699361 & \multicolumn{3}{|c|}{0.01908543} & & 1.938 & \\
\hline j86 & 1 & 0.11638318 & \multicolumn{3}{|c|}{0.02294717} & & 5.072 & \\
\hline SP & 1 & 0.08981530 & \multicolumn{3}{|c|}{0.02503811} & & 3.587 & \\
\hline ZLER & 1 & 0.02770221 & \multicolumn{3}{|c|}{0.01065135} & & 2.601 & \\
\hline :OMPU & 1 & 0.02366819 & \multicolumn{3}{|c|}{0.01161036} & & 2.039 & \\
\hline II LDBG & 1 & -0.02777377 & \multicolumn{3}{|c|}{0.01782330} & & -1.558 & \\
\hline ARBE & 1 & -0.01498247 & \multicolumn{3}{|c|}{0.01651710} & & -0.907 & \\
\hline JRB2 & 1 & -0.07516379 & \multicolumn{3}{|c|}{0.01991300} & & -3.775 & \\
\hline JMSABG & 1 & -0.04868516 & \multicolumn{3}{|c|}{0.01742432} & & -2.794 & \\
\hline J86 & 1 & -0.008715299 & \multicolumn{3}{|c|}{0.01077314} & & -0.809 & \\
\hline$\equiv D 86$ & 1 & 0.07346229 & \multicolumn{3}{|c|}{0.01246133} & & 5.895 & \\
\hline $5 \times 86$ & 1 & -0.03132578 & \multicolumn{3}{|c|}{0.01000409} & & -3.131 & \\
\hline$A C E 1$ & 1 & 0.04627430 & \multicolumn{3}{|c|}{0.02144111} & & 2.158 & \\
\hline ACE2 & 1 & 0.002502845 & \multicolumn{3}{|c|}{0.03562722} & & 0.073 & \\
\hline JE79 & 1 & 0.01360852 & \multicolumn{3}{|c|}{0.03175166} & & 0.429 & \\
\hline JES86 & 1 & -0.001897914 & \multicolumn{3}{|c|}{0.001662109} & & -1.142 & \\
\hline T86 & 1 & -0.02481247 & \multicolumn{3}{|c|}{0.03299292} & & -0.752 & \\
\hline TT86 & 1 & -0.12350933 & \multicolumn{3}{|c|}{0.03248187} & & -3.802 & \\
\hline XPWKBE & 1 & 0.001001729 & 0.000 & 2323 & & & 4.311 & \\
\hline XPWSBE & 1 & $5.67181 E-07$ & 4.345 & $55 E-$ & & & 1.304 & \\
\hline $\mathrm{T}:$ & & NUMERATOR: & 0.653603 & DF : & 1 & F VA & LUE: & 3.2736 \\
\hline & & DENOMINATOR: & 0.199658 & DF : & 4052 & PROB & $>F:$ & 0.0705 \\
\hline $\mathrm{T}:$ & & NUMERATOR: & 2. $9 E-05$ & DF : & 1 & F VA & LUE: & 0.0001 \\
\hline & & DENOM I NATOR: & 0.199658 & $D F:$ & 4052 & PROB & $>F=$ & 0.9904 \\
\hline
\end{tabular}

0.0001
0.0526
0.0795
0.4196
0.7604
0.0006
0.0013
0.0192
0.0001
0.0527
0.0001
0.0003
0.0093
0.0416
0.1192
0.3644
0.0002
0.0052
0.4186
0.0001
0.0018
0.0310
0.9418
0.6582
0.2536
0.4521
0.0001
0.0001
0.1923 
VARIABLE: LWG85

19:06 SUNDAY, JANUARY 1 .

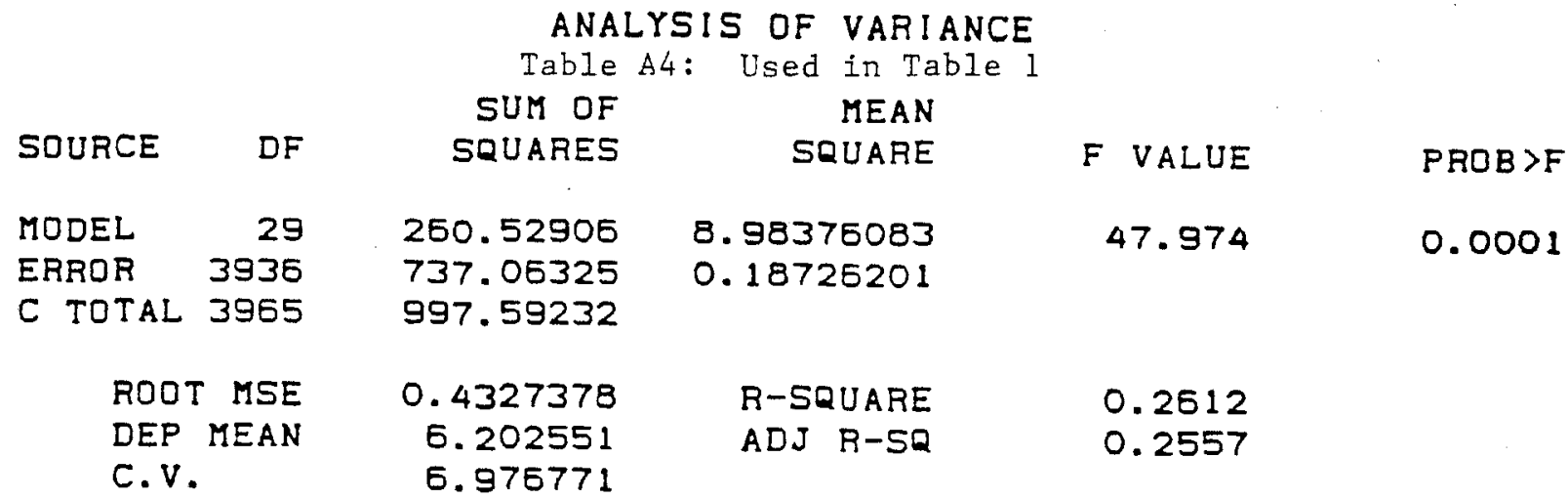

PARAMETER ESTIMATES

\begin{tabular}{|c|c|c|c|c|c|}
\hline VAR I ABLE & $D F$ & $\begin{array}{l}\text { PARAMETER } \\
\text { ESTIMATE }\end{array}$ & $\begin{array}{r}\text { STANDARD } \\
\text { ERROR }\end{array}$ & $\begin{array}{c}\text { T FOR HO: } \\
\text { PARAMETER }=0\end{array}$ & PROB $>I T:$ \\
\hline INTERCEP & 1 & 5.44462558 & 0.41547019 & 13.073 & 0.0001 \\
\hline TMATH & 1 & 0.04180377 & 0.01355472 & 3.051 & 0.0022 \\
\hline TVERB AL & 1 & 0.02990472 & 0.01535018 & 1.947 & 0.0515 \\
\hline TSCI & 1 & 0.005144783 & 0.01450274 & 0.355 & 0.7228 \\
\hline YOCT & 1 & -0.01608783 & 0.01777810 & -0.905 & 0.3556 \\
\hline UNL85 & 1 & -0.000533187 & 0.000253232 & -2.106 & 0.0353 \\
\hline CPT85 & 1 & 0.16811286 & 0.03208177 & 5.240 & 0.0001 \\
\hline HSG85 & 1 & 0.03221359 & 0.02513510 & 1.233 & 0.2178 \\
\hline NE85 & 1 & 0.14216278 & $0.0225 E 272$ & 5.301 & 0.0001 \\
\hline 5085 & 1 & 0.02790681 & 0.01924384 & 1.450 & 0.1471 \\
\hline VS85 & 1 & 0.05992416 & 0.02256998 & 2.555 & 0.0080 \\
\hline$H 1 S P$ & 1 & 0.05452065 & 0.02467751 & 2.515 & 0.0090 \\
\hline TCLER & 1 & 0.02928813 & 0.01039625 & 2.817 & 0.0049 \\
\hline TCOMPU & 1 & 0.02087852 & 0.01150049 & 1.815 & 0.0695 \\
\hline 585 & 1 & -0.01048739 & 0.04974204 & -0.211 & 0.8330 \\
\hline CHILDB5 & 1 & -0.04077569 & 0.01784580 & -2.285 & 0.0224 \\
\hline MAR85 & 1 & 0.01734561 & 0.01570285 & 1.038 & 0.2991 \\
\hline RUR82 & 1 & -0.03333385 & 0.01988319 & -1.575 & 0.0937 \\
\hline NSMSABS & 1 & -0.06965648 & 0.01705001 & -4.085 & 0.0001 \\
\hline EDB5 & 1 & -0.007926095 & 0.01070195 & -0.741 & 0.4590 \\
\hline CED85 & 1 & 0.05681298 & 0.01243780 & 4.568 & 0.0001 \\
\hline EDX85 & 1 & -0.01596224 & 0.01128178 & -1.415 & 0.1572 \\
\hline RACE 1 & 1 & 0.05240495 & 0.02119592 & 2.472 & 0.0135 \\
\hline RACE2 & 1 & 0.05050919 & 0.03513972 & 1.437 & 0.1507 \\
\hline AGE79 & 1 & 0.02286001 & 0.02851175 & 0.802 & 0.4227 \\
\hline AGES85 & 1 & -0.001580480 & 0.001562340 & -0.951 & 0.3418 \\
\hline ATB5 & 1 & -0.06133828 & 0.03216264 & -1.907 & 0.0566 \\
\hline ATT85 & 1 & -0.11983919 & 0.04063038 & -2.949 & 0.0032 \\
\hline EXPWK85 & 1 & 0.001521154 & 0.000245387 & 5.199 & 0.0001 \\
\hline EXPUSB & 1 & -0.001591255 & 0.001379442 & -1.154 & 0.2488 \\
\hline
\end{tabular}

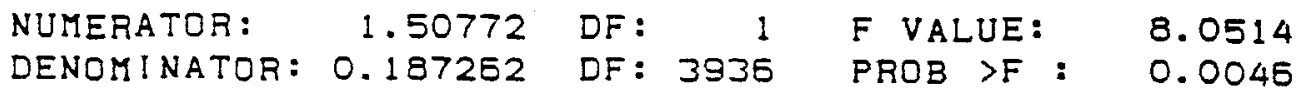

NUMERATOR: .0535464 DF: 1 F VALUE: 0.2859 DENOMINATOR: 0.187262 . DF: 3936 PROB >F: 0.5929 
VARIABLE: LEARN85

\begin{tabular}{|c|c|c|c|c|c|}
\hline \multirow[b]{2}{*}{ SOURCE } & \multicolumn{4}{|c|}{$\begin{array}{l}\text { ANALYSIS OF VARIANCE } \\
\text { Table A5: Used in Table } 2\end{array}$} & \multirow[b]{2}{*}{$P R O B>F$} \\
\hline & $D F$ & $\begin{array}{r}\text { SUM OF } \\
\text { SQUARES }\end{array}$ & $\begin{array}{r}\text { MEAN } \\
\text { SQUARE }\end{array}$ & F VALUE & \\
\hline MODEL & 29 & 1322.22534 & 45.59397722 & 88.060 & 0.0001 \\
\hline ERROR & 4492 & 2325.78181 & 0.51776087 & & \\
\hline C TOTAL & 4521 & 3648.00715 & & & \\
\hline $\begin{array}{l}\text { ROOT } \\
\text { DEP } \\
\text { C. V. }\end{array}$ & $\begin{array}{l}\text { MSE } \\
\text { MEAN }\end{array}$ & $\begin{array}{l}0.719556 \\
9.229141 \\
7.796566\end{array}$ & $\begin{array}{l}R-S Q U A R E \\
A D J \quad R-S Q\end{array}$ & $\begin{array}{l}0.3625 \\
0.3583\end{array}$ & \\
\hline
\end{tabular}

\section{PARAMETER ESTIMATES}

\begin{tabular}{|c|c|c|}
\hline$A R \ A B L E$ & $D F$ & $\begin{array}{l}\text { PARAMETER } \\
\text { EST IMATE }\end{array}$ \\
\hline NTERCEP & 1 & 8.28388905 \\
\hline MATH & 1 & -0.03727279 \\
\hline VERBAL & 1 & 0.01411218 \\
\hline $5 C 1$ & 1 & -0.02085496 \\
\hline OCT & 1 & 0.13347029 \\
\hline INL85 & 1 & -0.003540862 \\
\hline :PT85 & 1 & 0.48135176 \\
\hline 15G85 & 1 & 0.09951281 \\
\hline !E85 & 1 & 0.14018820 \\
\hline ;085 & 1 & 0.05389730 \\
\hline 1585 & 1 & 0.10584306 \\
\hline IISP & 1 & 0.05672807 \\
\hline 'CLER & 1 & 0.003586204 \\
\hline COMPU & 1 & 0.11865953 \\
\hline ;85 & 1 & -0.68182220 \\
\hline ;H ILD85 & 1 & 0.05225652 \\
\hline IAR85 & 1 & 0.18463553 \\
\hline IUR82 & 1 & -0.12498705 \\
\hline ISMSA85 & 1 & 0.07652404 \\
\hline :D85 . & 1 & 0.06527947 \\
\hline :EDS5 & 1 & 0.008123332 \\
\hline :DX85 & 1 & -0.05346193 \\
\hline RACE & 1 & -0.008876566 \\
\hline IACE2 & 1 & 0.04589225 \\
\hline 1GE79 & 1 & -0.007113356 \\
\hline ¿GES85 & 1 & -0.001721455 \\
\hline 1785 & 1 & -0.18557653 \\
\hline ITT85 & 1 & -0.20944943 \\
\hline :XPWK85 & 1 & 0.003265187 \\
\hline :XPWS85 & 1 & -0.005562980 \\
\hline
\end{tabular}

\section{STANDARD ERROR}

0.51518125
0.02096176
0.02331919
0.02242950
0.02132688

0.000403998

0.05659768

0.03671413

0.03445012

0.02973431

0.03387825

0.03745047

0.01751068

0.01812447

0.08079514

0.03031277

0.03094106

0.02991784

0.02519581

0.01368494

0.01694630

0.01727591

0.03267021

0.05268597

0.04325685

0.002554291

0.05074532

0.06436513

0.000363466

0.002069526
$T$ FOA HO:

PARAMETER $=0$

13.444 .

$-1.778$

0.605

$-0.930$

6.258

$-8.765$

8.505

2.710

4.068

1.813

3.124

1. 515

0.205

5.547

$-8.439$

1. 724

5.967

$-4.178$

3.037

4. 843

0.479

$-3.095$

$-0.272$

0.871

$-0.164$

$-0.674$

$-3.657$

$-3.254$

8. 983

$-2.688$
$P R O B>I T:$

0.0001

0.0754

0.5451

0.3525

0.0001

0.0001

0.0001

0.0067

0.0001

0.0700

0.0018

0.1299

0.8377

0.0001

0.0001

0.0848

0.0001

0.0001

0.0024

0.0001

0.6317

0.0020

0.7859

0.3838

0.8694

0.5004

0.0003

0.0011

0.0001

0.0072

jT:

NUMERATOR:

7.90379

DF :

DF: 4492

F VALUE:

15.2553

DENOMINATOR:

PROB $>F$ :

0.0001

IT:

NUMERATOR:

1. 18014

$D F:$

1

F VALUE:

2.2793

DENOMINATOR:

0.517761

$D F: 4492$

PROB $>F$ :

0.1312 
FEMALE LOG EARNINGS VOC IS TRADE AND TECH,ACAD IS MT,SCI. ENG

VARIABLE: LEARNB5

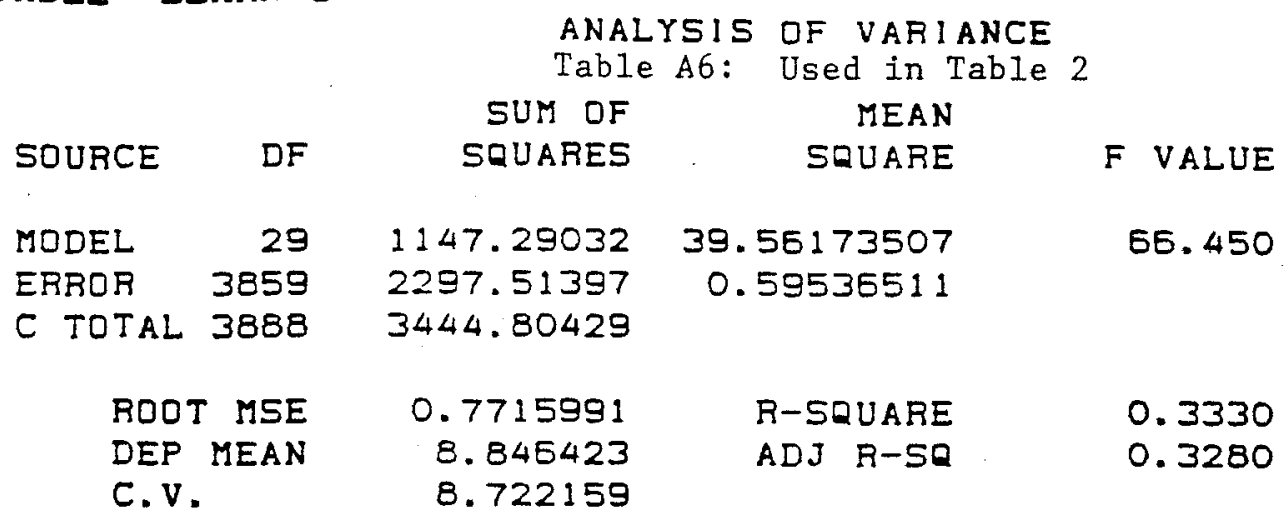

PARAMETER ESTIMATES

\begin{tabular}{|c|c|c|}
\hline VARIABLE & $D F$ & $\begin{array}{l}\text { PARAMETER } \\
\text { ESTIMATE }\end{array}$ \\
\hline INTERCEP & 1 & 5.77335340 \\
\hline TMATH & 1 & 0.05478352 \\
\hline TVERBAL & 1 & 0.03865029 \\
\hline TSC I & 1 & 0.008837114 \\
\hline VOCT & 1 & -0.02033731 \\
\hline UNL85 & 1 & -0.001500858 \\
\hline CPT 85 & 1 & 0.54151535 \\
\hline H5G85 & 1 & 0.01107340 \\
\hline NE85 & 1 & 0.09558597 \\
\hline 50.85 & 1 & 0.10152750 \\
\hline US85 & 1 & -0.03027610 \\
\hline HISP & 1 & 0.18488413 \\
\hline TCLER & 1 & 0.02153457 \\
\hline TCOMPU & 1 & 0.05335899 \\
\hline SB5 & 1 & -0.52280714 \\
\hline CH1LD85 & 1 & -0.21963136 \\
\hline MARB5 & 1 & -0.07358241 \\
\hline RURB2 & 1 & -0.09297968 \\
\hline NSMSABS & 1 & -0.004511564 \\
\hline ED85 & 1 & 0.04595464 \\
\hline CED85 & 1 & 0.04224277 \\
\hline EDX85 & 1 & -0.03223493 \\
\hline RACE 1 & 1 & 0.08524517 \\
\hline ACE2 & 1 & -0.005185724 \\
\hline E79 & 1 & 0.06432451 \\
\hline IES85 & 1 & -0.005540288 \\
\hline 85 & 1 & -0.18375782 \\
\hline T85 & 1 & -0.18747008 \\
\hline PUK85 & 1 & 0.003461555 \\
\hline PVS85 & 1 & -0.00227599 \\
\hline
\end{tabular}

STANDARD

ERROR

0.74930725
0.02434109
0.02759419
0.02503885
0.03159744

0.000457043

0.05575235

0.04774354

0.03995000

0.03433952

0.04027130

0.04459821

0.01889925

0.02055725

0.08589155

0.03244244

0.03023968

0.03570420

0.02998459

0.01993019

0.02283587

0.01988179

0.03812160

0.05359035

0.05124828

0.002985473

0.05724179

0.07090204

0.000425091

0.002436580
21:25 SUNDAY,

JANUARY 1,1989

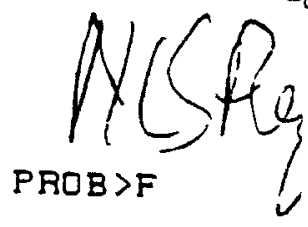

0.0001
PROB > IT:
0.0001

0.0078

0.1613

0.7343

0.5212

0.0005

0.0001

0.8156

0.0158

0.0031

0.4522

0.0001

0.2545

0.0095

0.0001

0.0001

0.0149

0.0092

0.8804

0.0212

0.0544

0.1050

0.0237

0.9350

0.2095

0.0285

0.0013

0.0082

0.0001

0.3503

ST:

NUMERATOR:

3.04129

DF:

1

F VALUE:

5.1083

DENOMINATOR:

0.595365

DF: 3859

PROB $>F$ :

0.0239

ST:

NUMERATOR:

0.256403

$D F: \quad 1$

F VALUE:

0.4307

DENOMINATOR:

0.595355

DF: 3859

$P R O B>F$ :

0.5117 
VARIABLE : EARN85

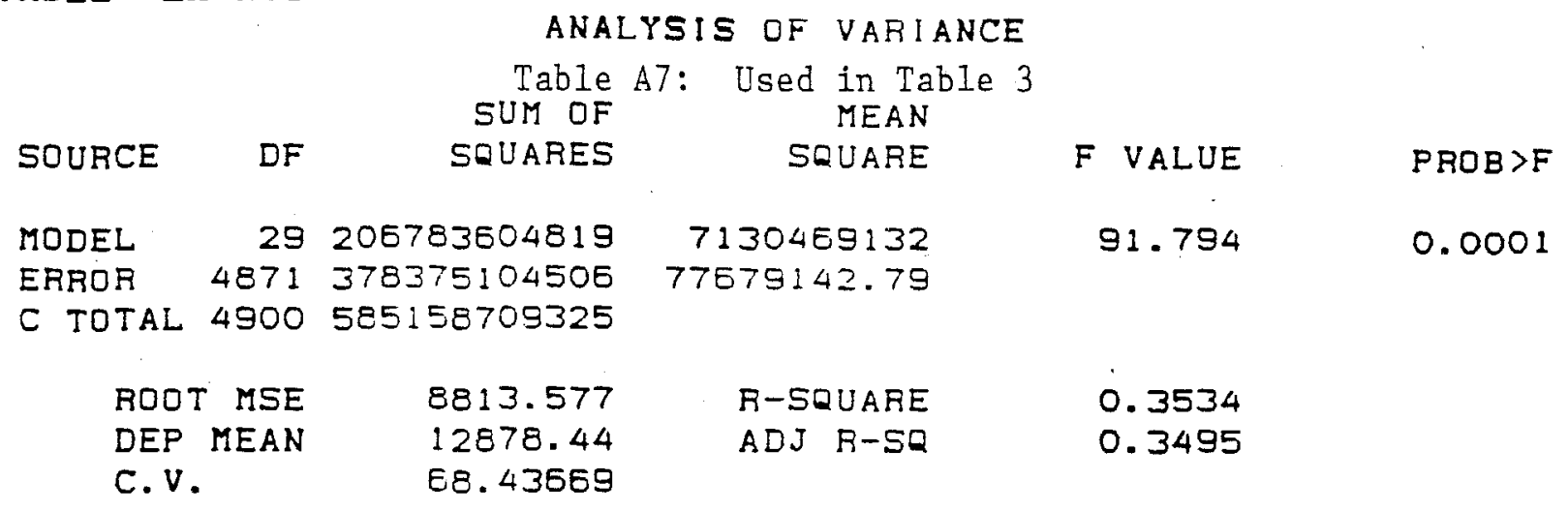

PARAMETER ESTIMATES

\begin{tabular}{|c|c|c|}
\hline$A R$ I $A B L E$ & DF & $\begin{array}{l}\text { PARAMETER } \\
\text { EST IMATE }\end{array}$ \\
\hline NTERCEP & 1 & 13528.10963 \\
\hline MATH & 1 & -96.38050842 \\
\hline VERBAL & 1 & -87.53451686 \\
\hline SC 1 & 1 & -218.04778 \\
\hline $\mathrm{OCT}$ & 1 & 1354.75443 \\
\hline NL85 & 1 & -38.81934631 \\
\hline PT85 & 1 & 3879.54912 \\
\hline .5685 & 1 & 1422.45819 \\
\hline E85 & 1 & 1110.74485 \\
\hline 085 & 1 & 189.33661 \\
\hline 585 & 1 & $\$ 148.79439$ \\
\hline $1 S P$ & 1 & 478.85140 \\
\hline CLER & 1 & 286.56038 \\
\hline COMPU & 1 & 1240.51980 \\
\hline$: 85$ & 1 & -6445.60032 \\
\hline :HILD85 & 1 & -54.77381359 \\
\hline ARB5 & 1 & 2771.54118 \\
\hline UR82 & 1 & $-981.64 E 78$ \\
\hline SMSA85 & 1 & 45.51505359 \\
\hline D85 & 1 & 556.33945 \\
\hline ED85 & 1 & 651.84781 \\
\hline $0 \times 85$ & $i$ & -856.38595 \\
\hline$A C E 1$ & 1 & 107.54640 \\
\hline ACE2 & 1 & 318.47445 \\
\hline GE79 & 1 & -615.69675 \\
\hline GES85 & 1 & 14.73497494 \\
\hline T85 & 1 & -2051.81816 \\
\hline TT85 & 1 & -2193.31651 \\
\hline XPWK85 & 1 & 17.94502089 \\
\hline XPWS85 & 1 & 52.80562382 \\
\hline
\end{tabular}

STANDARD
ERROR
7181.51285
247.89011
272.54002
250.83248
251.53490
4.71382354
$575.16 E 44$
428.78833
404.00132
347.84319
397.21834
439.35544
206.58960
$212.02 E 05$
921.77771
352.36410
364.05574
352.93028
295.64493
153.65179
193.59691
200.72702
377.78032
514.34307
504.39673
29.91531301
$599.0290 E$
751.22885
4.00024479
23.45151878

$T$ FOR HO:

PARAMETER $=0$

1.898

$-0.389$

$-0.321$

$-0.835$

5.424

$-8.235$

5.746

3.317

2.749

0.544

2.887

1.090

1.387

5.851

$-5.993$

$-0.155$

7.513

$-2.781$

0.154

3.621

3.367

$-4.266$

0.285

0.518

$-1.221$

0.493

$-3.425$

$-2.920$

4.486

2.252
PROB $>I T:$

0.0578

0.6974

0.7482

0.4032

0.0001

0.0001

0.0001

0.0009

0.0060

0.5862

0.0039

0.2758

0.1655

0.0001

0.0001

0.8765

0.0001

0.0054

0.8777

0.0003

0.0008

0.0001

0.7757

0.5042

0.2223

0.6224

0.0005

0.0035

0.0001

0.0244

$T:$

NUMERATOR:

$8.5 E+08$

$\begin{array}{lr}D F: & 1 \\ D F: & 4871\end{array}$

F VALUE:

10.8982

DENOMINATOR:

77679143

$P A O B>F$ :

0.0010

NUMERATOR: $\quad 38077.3$ DF: 1 DENOMINATOR: 77579143 DF: 4871
F VALUE:

$P R O B>F$ :
0.0005

0.9823 


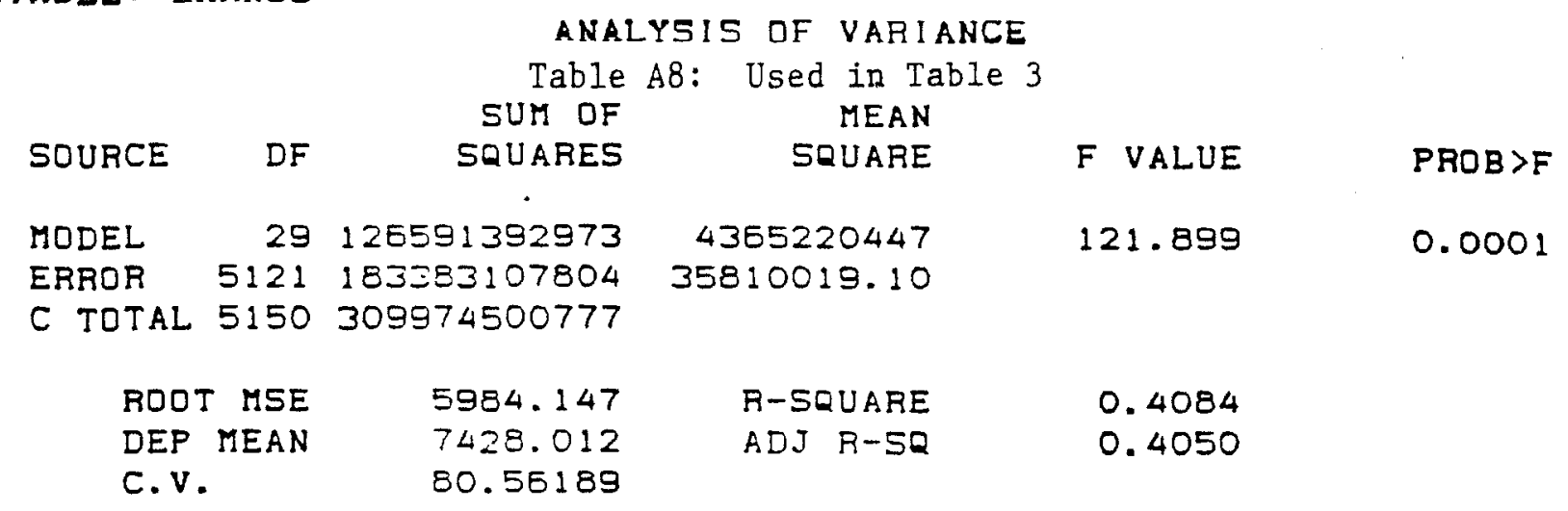

PARAMETER ESTIMATES

\begin{tabular}{|c|c|c|}
\hline VAR I ABLE & DF & $\begin{array}{l}\text { PARAMETER } \\
\text { ESTIKATE }\end{array}$ \\
\hline INTERCEP & 1 & -4970.35635 \\
\hline TMATH & 1 & 813.35990 \\
\hline TVERBAL & 1 & 94.48922727 \\
\hline TSC 1 & 1 & 29.62771998 \\
\hline VOCT & 1 & -170.90553 \\
\hline UNL85 & 1 & -14.64903278 \\
\hline CPTBS & 1 & 4245.77442 \\
\hline HSG85 & 1 & 424.17422 \\
\hline NE85 & 1 & 673.28595 \\
\hline 5085 & 1 & 633.58595 \\
\hline 4585 & 1 & 44.56335575 \\
\hline$H 1 S P$ & 1 & 769.73235 \\
\hline TCLER & 1 & 240.58063 \\
\hline TCOMPU & 1 & 438.46415 \\
\hline 585 & 1 & -2570.77561 \\
\hline CH I LD85 & 1 & -2285.83519 \\
\hline MAR85 & 1 & -595.46410 \\
\hline RUR82 & 1 & -498.72563 \\
\hline NSMSA85 & 1 & -241.99980 \\
\hline ED85 & 1 & 7. 1E323918 \\
\hline CED85 & 1 & 908.41325 \\
\hline EDX85 & 1 & -259.05532 \\
\hline RACE 1 & 1 & 587.30242 \\
\hline RACE2 & 1 & 142.25521 \\
\hline HGE79 & 1 & 536.83705 \\
\hline AGES85 & 1 & -53.84070316 \\
\hline AT85 & 1 & -1369.84295 \\
\hline ATT85 & 1 & -1881.20154 \\
\hline EXPWK85 & 1 & 16.08315784 \\
\hline EXPU585 & 1 & 51.81671755 \\
\hline
\end{tabular}

$$
\begin{array}{r}
\text { STANDARD } \\
\text { ERROR } \\
4847.70536 \\
168.51409 \\
183.73117 \\
175.11014 \\
218.72808 \\
3.02003808 \\
415.88724 \\
293.32122 \\
259.87826 \\
225.89182 \\
259.27544 \\
292.77319 \\
127.00746 \\
135.15226 \\
516.00371 \\
215.63390 \\
200.17729 \\
238.48162 \\
202.37198 \\
103.21858 \\
129.44310 \\
135.88058 \\
252.00407 \\
404.74414 \\
334.64517 \\
19.56549440 \\
407.24305 \\
510.95977 \\
2.50662177 \\
15.31174202 \\
\end{array}
$$

NUMERATOR:

2. $7 E+08$

$D F:$
35810019 DF: 5121
T FOR HO:

PARAMETER $=0$

$$
\begin{array}{r}
-1.025 \\
4.824 \\
0.514 \\
0.159 \\
-0.781 \\
-4.851 \\
10.209 \\
1.445 \\
2.495 \\
2.792 \\
0.155 \\
2.529 \\
1.895 \\
3.220 \\
-4.173 \\
-10.552 \\
-2.975 \\
-2.091 \\
-1.195 \\
0.059 \\
7.018 \\
-1.980 \\
2.727 \\
0.351 \\
1.903 \\
-2.752 \\
-3.354 \\
-3.582 \\
5.415 \\
3.384
\end{array}
$$

PROB $>: T:$

0.3053

0.0001

0.5071

0.8557

0.4345

0.0001

0.0001

0.1482

0.0125

0.0053

0.8585

0.0085

0.0581

0.0013

0.0001

0.0001

0.0029

0.0365

0.2318

0.9447

0.0001

0.0477

0.0054

0.7252

0.0571

0.0059

0.0008

0.0002

0.0001

0.0007

ST:

$\begin{array}{lrlr}\text { NUMERATOR: } & 2.6 E+08 & \text { DF: } & 1 \\ \text { DENOMINATOR: } & 35810019 & \text { DF: } 5121\end{array}$

F VALUE:

7.1551

PROB $>F$ :

0.0075 


\begin{tabular}{|c|c|c|c|c|c|}
\hline \multirow[b]{2}{*}{ SOURCE } & \multicolumn{5}{|c|}{$\begin{array}{l}\text { ANALYSIS OF VARIANCE } \\
\text { Table A9: Used in Table } 4\end{array}$} \\
\hline & DF & $\begin{array}{l}\text { SUM OF } \\
\text { SQUARES }\end{array}$ & $\begin{array}{r}\text { MEAN } \\
\text { SQUARE }\end{array}$ & F VALUE & $P R O B>F$ \\
\hline MODEL & 29 & 54.71739515 & 1.88680673 & 40.993 & 0.0001 \\
\hline ERROR & 4430 & 203.90126 & 0.04502737 & & \\
\hline C TOTAL & 4459 & 258.61865 & & & \\
\hline $\begin{array}{l}\text { ROO } \\
\text { DEP } \\
\text { C.V }\end{array}$ & $\begin{array}{l}\text { MSE } \\
\text { MEAN }\end{array}$ & $\begin{array}{r}0.2145399 \\
0.1146414 \\
187.1399\end{array}$ & $\begin{array}{l}\text { R-SQUARE } \\
\text { ADJ R-SQ }\end{array}$ & $\begin{array}{l}0.2116 \\
0.2064\end{array}$ & \\
\hline
\end{tabular}

PARAMETER ESTIMATES

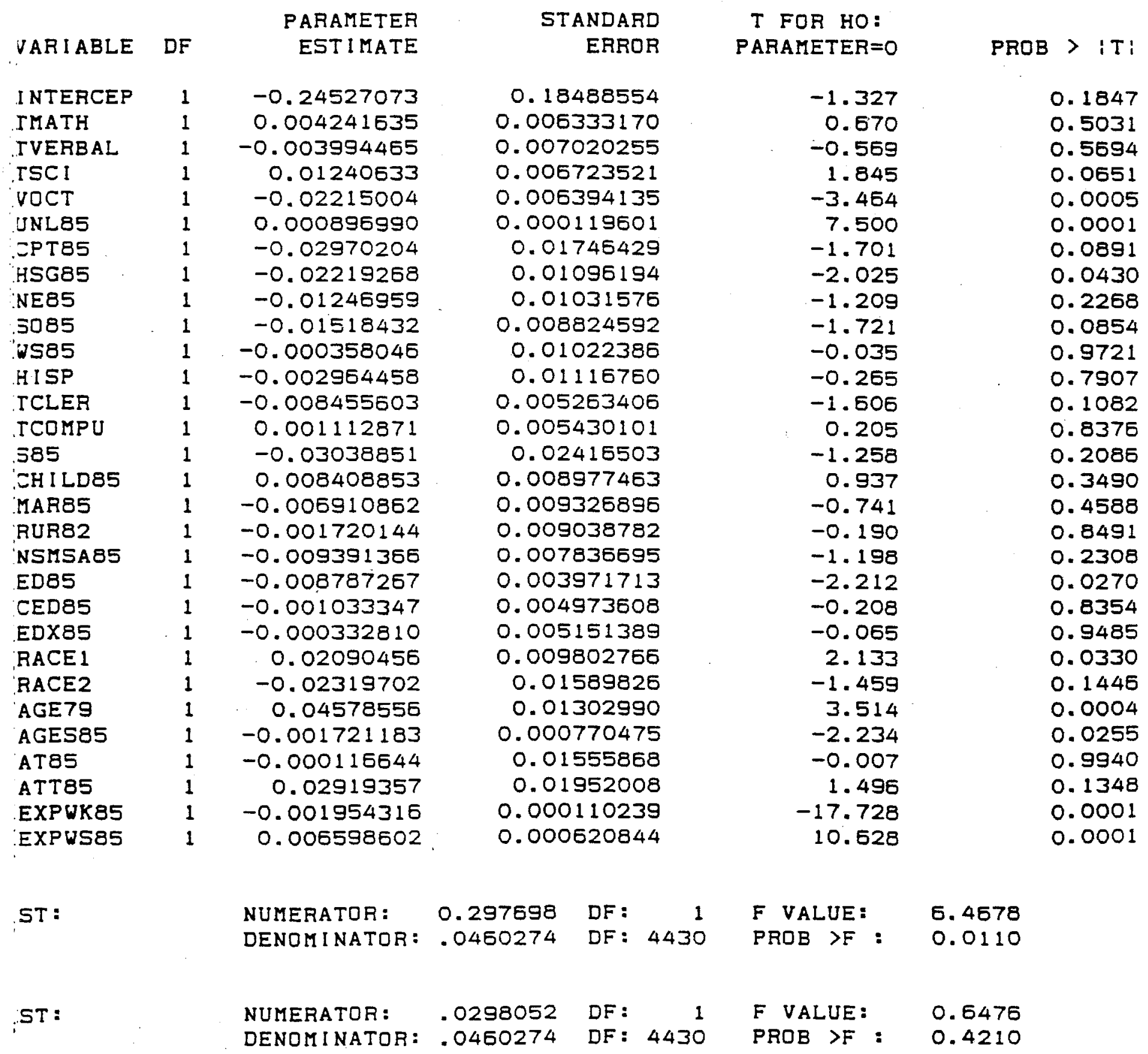


VARIABLE: UN85

\begin{tabular}{|c|c|c|c|c|c|}
\hline \multirow[b]{2}{*}{ SOURCE } & \multicolumn{4}{|c|}{$\begin{array}{l}\text { ANALYSIS DF VARIANCE } \\
\text { Table A10: Used in Table } 4\end{array}$} & \multirow[b]{2}{*}{$P R O B>F$} \\
\hline & DF & $\begin{array}{l}\text { SUM OF } \\
\text { SQUARES }\end{array}$ & $\begin{array}{r}\text { MEAN } \\
\text { SQUARE }\end{array}$ & F VALUE & \\
\hline $\begin{array}{l}\text { MODEL } \\
\text { ERROR } \\
\text { C TOTAL }\end{array}$ & $\begin{array}{r}29 \\
4194 \\
4223\end{array}$ & $\begin{array}{r}55.79809034 \\
211.86173 \\
257.65982\end{array}$ & $\begin{array}{l}1.92407208 \\
0.05051543\end{array}$ & 38.089 & 0.0001 \\
\hline $\begin{array}{l}\text { ROOT } \\
\text { DEP } \\
C . V .\end{array}$ & $\begin{array}{l}\text { MSE } \\
\text { MEAN }\end{array}$ & $\begin{array}{r}0.2247554 \\
0.1140849 \\
197.0081\end{array}$ & $\begin{array}{l}\text { R-SQUARE } \\
\text { ADJ R-SQ }\end{array}$ & $\begin{array}{l}0.2085 \\
0.2030\end{array}$ & \\
\hline
\end{tabular}

PARAMETER ESTIMATES

\begin{tabular}{|c|c|c|}
\hline VARI ABLE & DF & $\begin{array}{l}\text { PARAMETER } \\
\text { ESTIMATE }\end{array}$ \\
\hline |NTERCEP & 1 & -0.174066 \\
\hline TMATH & 1 & -0.0052409 \\
\hline TVERBAL & 1 & -0.017422 \\
\hline ISC I & 1 & -0.0031809 \\
\hline VOCT & 1 & 0.0057173 \\
\hline UNL85 & 1 & 0.0005321 \\
\hline CPT85 & 1 & -0.0359893 \\
\hline 15G85 & 1 & -0.0045612 \\
\hline NE85 & 1 & -0.0218718 \\
\hline 185 & 1 & -0.0103358 \\
\hline 585 & 1 & -0.01199 \\
\hline $15 P$ & 1 & -0.01896 \\
\hline TCLER & 1 & -0.0064 \\
\hline ICOMPU & 1 & 0.00479992 \\
\hline 585 & 1 & -0.05982 \\
\hline CHI LD85 & 1 & 0.012539 \\
\hline MAR85 & 1 & -0.0245788 \\
\hline RUR82 & 1 & 0.0095302 \\
\hline WSHSAB5 & 1 & -0.0039297 \\
\hline ED85 & 1 & -0.01289 \\
\hline CED85 & 1 & 0.0096791 \\
\hline EDX85 & 1 & -0.0093041 \\
\hline CE 1 & 1 & 0.046068 \\
\hline RACE2 & 1 & 0.04271 \\
\hline IGE 79 & 1 & 0.047558 \\
\hline ES85 & 1 & -0.002221 \\
\hline & 1 & 0.02353 \\
\hline 35 & 1 & 0.04738 \\
\hline & 1 & -0.00183 \\
\hline & 1 & \\
\hline
\end{tabular}

STANDARD

ERROR

0.20739210

0.005905117

0.007532930

0.007232158

0.008978740

0.000127343

0.01534271

0.01304187

0.01119556

0.009507520

0.01132147

0.01244751

0.005248137

0.005701175

0.02437541

0.008987849

0.008420201

0.009980984

0.008455239

0.005300229

0.005178310

0.005603241

0.01056939

0.01766838

0.01419780

0.000828123

0.01525178

0.02010905

0.000113161

0.000558752
T FOR HO:

PARAMETER $=0$

$-0.839$

$-0.759$

$-2.283$

$-0.440$

0.748

4.179

$-2.202$

$-0.350$

$-1.954$

$-1.087$

$-1.059$

$-1.524$

$-1.238$

0.842

$-2.864$

1.405

$-2.919$

0.955

$-0.465$

$-2.434$

1.567

$-1.660$

4.359

2.418

3.357

$-2.583$

1. 448

2. 357

$-15.242$

10.829
PROB $>I T i$

0.4013

0.4479

0.0225

0.6501

0.4544

0.0001

0.0277

0.7256

0.0508

0.2770

0.2895

0.1277

0.2157

0.3999

0.0042

0.1597

0.0035

0.3397

0.6421

0.0150

0.1173

0.0969

0.0001

0.0157

0.0008

0.0073

0.1475

0.0185

0.0001

0.0001

NUMERATOR: 0.195553 DF: 1 F VALUE: 3.8733 DENOMINATOR: .0505154 DF: 4194 PROB $>F: \quad 0.0491$

NUMERATOR: 0.060527 DF: 1 F VALUE: 1.1982 DENOMINATOR: .0505154 DF: 4194 PROB $>F: 0.2737$ 
MODELS WITH CROSS EQUATION CONSTRAINTS

NO WORK EXPER INTERACTIONS AND TECH VOC AND HS ACAD \& SCH ATT

\title{
NT GENERALIZED LEAST SQUARES
}

23:44 SUNDAY, JANUARY 8,1989

\author{
EL: E1 JGLS \\ VARIABLE: LWGBE
}

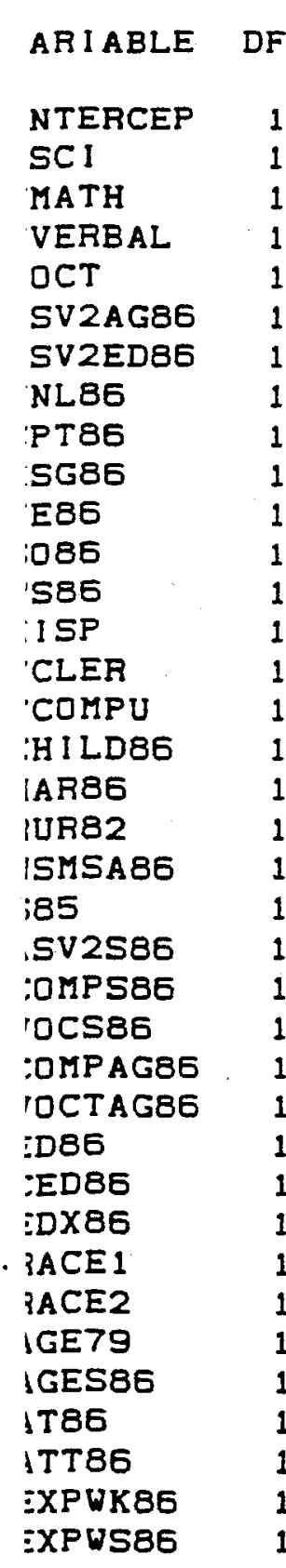

ST:
PARAMETER ESTIMATES

Table A 11: Used in Table 5 PARAMETER ESTIMATE

5.70283895

$-0.002861527$

$-0.005303968$

$-0.01620374$

0.04352065

$-0.002016640$

0.006932437

$-0.03640345$

0.08935393

$-0.01316534$

0.08966390

0.01824856

0.09053210

0.05969784

$-0.003573519$

0.06179075

$-0.007862752$

0.07580855

$-0.04302263$

$-0.08246078$

$-0.11335857$

$-0.02553527$

$-0.005835270$

0.01157150

0.005725466

0.006677902

0.02755818

0.002896352

$-0.01764958$

0.03051627

$-0.009054418$

0.02591664

$-0.001091081$

0.08820811

$-0.15447328$

0. 000823742

$-7.95860 E-08$
STANDARD

ERROR

0.57634418

0.01285523

0.01229865

0.01337480

0.01289718

0.003859981

0.005395494

0.009278103

0.04121523

0.02937111

0.02740784

0.02289530

0.02654872

0.03034802

0.009812371

0.01114846

0.02065286

0.02031719

0.02370117

0.01992431

0.07154521

0.02060333

0.01471543

0.01830280

0.002490305

0.003173920

0.01148826

0.01520452

0.01277824

0.02805784

0.04760470

0.04321489

0.002226428

0.05026902

0.04122734

0.000512308

$7.50035 \mathrm{E}-07$
T FOR HO:
PARAMETER $=0$

9.895

$-0.223$

$-0.431$

$-1.212$

3. 374

$-0.521$

1. 285

$-3.924$

2. 168

$-0.448$

3.271

0.797

3.414

1. 967

$-0.364$

5.543

$-0.381$

3.780

$-1.815$

$-4.139$

$-1.585$

$-1.239$

$-0.397$

0.638

2. 299

2. 104

2. 399

0.190

$-1.381$

1.088

$-0.190$

0.600

$-0.490$

1.755

$-3.747$

1.608

$-0.106$
PROB > $>\mathrm{T}:$

0.0001

0.8239

0.6563

0.2258

0.0008

0.5024

0.1990

0.0001

0.0303

0.6540

0.0011

0.4255

0.0007

0.0493

0.7158

0.0001

0.7035

0.0002

0.0696

0.0001

0.1132

0.2153

0.6917

0.5237

0.0216

0.0355

0.0165

0.8489

0.1674

0.2769

0.8492

0.5488

0.5241

0.0795

0.0002

0.1080

0.9155
NUMERATOR:

DENOMINATOR:
6.05379

0.993772
$D F$ :

$D F: 12780$
F VALUE:

PROB $>F$ :
6. 0917

0.0136 
MODELS WITH CROSS EQUATION CONSTRAINTS

NO WORK EXPER INTERACTIONS AND TECH VOC AND HS ACAD \& SCH ATT

CONSTRAINTS ON ALL TESTS

HINT GENERALIZED LEAST SQUARES

male Loq Earnings 20:24 SUNDAY, JANUARY 8, 1989

JDEL: E2 JGLS

PP VARIABLE: LEARNB5

VARIABLE DF

PARAMETER ESTIMATE

INTERCEP 1

TSCI 1

TMATH 1

TVERBAL 1

VOCT

ASV2AG85

ASV2ED85

UNL85

CPT85

HSG85

NE85

5085

US85

HISP

TCLER

TCOMPU

CHILD85

MARB5

RUR82

NSMSA 85

585

ASV2S85

COMPSB5

VOCS85

COMPAG85

VOCTAGB5

ED85

CED85

EDX85

RACE 1

RACE2

AGE79

AGES85

AT85

ATT85

EXPWK85

EXPUS85

EST:
7.75548357

$-0.009227758$

$-0.01521455$

$-0.01495466$

0.08742264

0.003963008

$-0.01291844$

$-0.002400825$

0.20014773

0.02862823

0.11817005

$-0.01017905$

0.05451287

$-0.01799718$

0.01707900

0.09531613

0.05073238

0.08956626

$-0.05975132$

$-0.005888160$

$-0.72402440$

$-0.23672406$

0.000258026

0.14138707

0.001584462

$-0.000582258$

0.04094066

0.05026349

$-0.05237297$

$-0.07024504$

0.03356020

0.08321575

$-0.004016427$

$-0.10497770$

$-0.07300787$

0.000128220

0.004381317
NUMERATOR:
PARAMETER ESTIMATES

e A 12: Used in Table 5

\begin{abstract}
STANDARD
\end{abstract}
ERROR

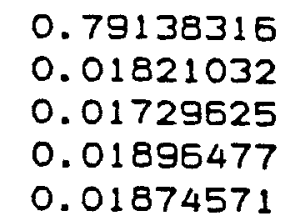

0.005531239

0.008051220

0.000412575

0.05208693

0.03895451

0.03610236

0.03131534

0.03483479

0.03986741

0.01357622

0.01585485

0.02935289

0.02876692

0.03179125

0.02590199

0.08014343

0.04749581

0.03279502

0.04041948

0.004278135

0.005454428

0.01513072

0.02080705

0.01904028

0.03545818

0.05809073

0.05521983

0.003155860

0.05138120

0.06126134

0.000429188

0.002281171
T FOR HO:

PARAMETER $=0$

9.800
-0.507
-0.880
-0.789
4.664
0.598
-1.503
-5.819
3.843
0.735
3.273
-0.325
1.568
-0.451
1.258
0.012
1.728
3.114
-1.880
-0.227
-9.034
-4.984
0.008
3.498
0.394
-0.125
2.706
2.416
-2.751
-1.981
0.578
1.507
-1.272
-2.043
-1.192
0.299
1.921
PROB $>\mid T:$

0.0001

0.5124

0.3791

0.4304

0.0001

0.5501

0.1091

0.0001

0.0001

0.4626

0.0011

0.7452

0.1170

0.5517

0.2085

0.0001

0.0840

0.0019

0.0502

0.8202

0.0001

0.0001

0.9935

0.0005

0.6938

0.9005

0.0069

0.0158

0.0050

0.0477

0.5635

$0.131 \mathrm{I}$

0.2034

0.0411

0.2335

0.7552

0.054 I

EST:

9.99361

$D F$ :

$D F: 15143$

F VALUE: $\quad 10.1133$

DENOMINATOR: 0.988161

PROB >F :

0.0015

NUMERATOR:

8. 9E-05

$D F:$

1

F VALUE:

0.0001

DENOMINATOR:

DF : 15143

$P R O B>F$ :

0.9924 
JOINT GENERALIZED LEAST SQUARES

1ODEL : E2

JGLS

JEP VARIABLE: EARN85

$\begin{array}{ll}\text { VARIABLE } & \text { DF } \\ \text { INTERCEP } & 1 \\ \text { TSCI } & 1 \\ \text { TMATH } & 1 \\ \text { TVERBAL } & 1 \\ \text { VOCT } & 1 \\ \text { ASV2AG85 } & 1 \\ \text { ASV2ED85 } & 1 \\ \text { UNL85 } & 1 \\ \text { CPT85 } & 1 \\ \text { HSG85 } & 1 \\ \text { NE85 } & 1 \\ \text { SO85 } & 1 \\ \text { WS85 } & 1 \\ \text { HISP } & 1 \\ \text { TCLER } & 1 \\ \text { TCOMPU } & 1 \\ \text { CHILD85 } & 1 \\ \text { MAR85 } & 1 \\ \text { RUR82 } & 1 \\ \text { NSMSA85 } & 1 \\ \text { S85 } & 1 \\ \text { ASV2S85 } & 1 \\ \text { COMPS85 } & 1 \\ \text { VOCS85 } & 1 \\ \text { COMPAG85 } & 1 \\ \text { VOCTAG85 } & 1 \\ \text { ED85 } & 1 \\ \text { CED85 } & 1 \\ \text { EDX85 } & 1 \\ \text { RACE1 } & 1 \\ \text { RACE2 } & 1 \\ \text { AGE79 } & 1 \\ \text { AGES85 } & 1 \\ \text { AT85 } & 1 \\ \text { ATT85 } & 1 \\ \text { EXPVK85 } & 1 \\ \text { EXPVS85 } & 1 \\ & \end{array}$

PARAMETER ESTIMATES

Table A 13: Used in Table 5

PARAMETER

EST IMATE

0.10167441

$-0.005607194$

0.008557542

$-0.04383964$

0.13330809

$-0.000532372$

$-0.01687833$

$-0.003161606$

0.14050602

0.07790490

0.12674510

0.02033390

0.09225884

0.06982571

0.03591198

0.10875499

0.03739709

0.13627287

$-0.07524851$

$-0.02793299$

$-0.51431789$

$-0.10962079$

$-0.06072772$

$-0.04963914$

0.01554175

0.007579674

0.06081492

0.07222084

$-0.09438636$

$-0.05137973$

$-0.02048484$

0.02632028

$-0.001259738$

$-0.09647023$

$-0.18242732$

0.001356388

0.003270853
STANDARD

ERROR

\begin{abstract}
0.93702289
0.01783830

0.01727857

0.01862457

0.01817911
\end{abstract}

0.006641986

0.007992357

0.000472414

0.06000743

0.04532946

0.04241354

0.03629804

0.04128938

0.04843606

0.01366944

0.01529030

0.03403551

0.03425021

0.03839898

0.02998132

0.08312323

0.04094282

0.02768483

0.03479288

0.004174240

0.005427247

0.01671769

0.02275356

0.02142926

0.04014248

0.06991393

0.06560144

0.003791497

0.05618091

0.06635518

0.000430231

0.002503406
I FOR HO:
PARAMETER $=0$

0.109

$-0.370$

0.495

$-2.354$

7.333

$-0.080$

$-2.112$

$-6.692$

2.341

1.719

2. 988

0.560

2. 234

1. 442

2. 527

7.113

1.099

3.979

$-1.960$

$-0.932$

$-6.187$

$-2.677$

$-2.194$

$-1.427$

3.723

1. 397

3.638

3.174

$-4.405$

$-1.280$

$-0.293$

0.401

$-0.332$

$-1.717$

$-2.749$

3.153

1. 307
PROB $>i T i$

0.9136

0.7111

0.6204

0.0186

0.0001

0.9361

0.0348

0.0001

0.0193

0.0858

0.0028

0.5754

0.0255

0.1495

0.0088

0.0001

0.2719

0.0001

0.0501

0.3516

0.0001

0.0074

0.0283

0.1537

0.0002

0.1626

0.0003

0.0015

0.0001

0.2005

0.7695

0.6883

0.7397

0.0860

0.0060

0.0016

0.1914

EST :

NUMERATOR: 20.0429 DF: 1 DENOMINATOR: 0.987471 DF:20483
F VALUE: $\quad 20.2972$ PROB $>F: 0.0001$ 
MALE UNEMPLOY

MODELS WITH CROSS EQUATION CONSTRAINTS

NO WORK EXPER INTERACTIONS AND TECH VOC AND HS ACAD \& SCH ATT CONSTRAINTS ON ALL TESTS

21:06 SUNDAY, JANUARY 8, 1989

INT GENERALIZED LEAST SQUARES

JGLS

DDEL: E2
PARIABLE: UNBS

\begin{tabular}{|c|c|c|c|c|c|}
\hline & & $\begin{array}{r}P \\
T a b\end{array}$ & $\begin{array}{l}\text { METER EST IMAT } \\
14: \text { Used in }\end{array}$ & 5 & \\
\hline & & PARAMETER & STANDARD & T FOR HO: & \\
\hline VARIABLE & DF & ESTIMATE & ERROR & PARAMETER $=0$ & $P R O B>: T:$ \\
\hline INTERCEP & 1 & -0.47148516 & 0.19682475 & -2.395 & 0.0157 \\
\hline TSCI & 1 & 0.01024567 & 0.005014504 & 2.043 & 0.0421 \\
\hline TMATH & 1 & -0.01242453 & 0.004861979 & -2.555 & 0.0106 \\
\hline TVERBAL & 1 & 0.000200128 & 0.005259774 & 0.038 & 0.9697 \\
\hline VOCT & 1 & -0.02169517 & 0.005438138 & -3.989 & 0.0001 \\
\hline ASV2AG85 & 1 & 0.004856227 & 0.002010370 & 2.416 & 0.0158 \\
\hline ASV2ED85 & 1 & 0.001724387 & 0.002373922 & 0.726 & 0.4677 \\
\hline UNL85 & 1 & 0.000735390 & 0.000119948 & 6.131 & 0.0001 \\
\hline CPT85 & 1 & -0.02910173 & 0.01599331 & -1.713 & 0.0859 \\
\hline H5G85 & 1 & -0.02187577 & 0.01137344 & -1.923 & 0.0545 \\
\hline NE85 & 1 & -0.02580211 & 0.01052965 & -2.450 & 0.0143 \\
\hline 5085 & 1 & -0.01774488 & 0.009097560 & -1.950 & 0.0512 \\
\hline WS85 & 1 & -0.007252651 & 0.01046394 & -0.693 & 0.4883 \\
\hline HISP & 1 & -0.000087137 & 0.01130023 & -0.008 & 0.9938 \\
\hline TCLER & 1 & -0.01083796 & 0.003790230 & -2.859 & 0.0043 \\
\hline TCOMPU & 1 & -0.004006007 & 0.004512896 & -0.888 & 0.3748 \\
\hline CHILD85 & 1 & 0.008180820 & 0.008964285 & 0.913 & 0.3515 \\
\hline MAR85 & 1 & -0.01272778 & 0.009173501 & -1.387 & 0.1654 \\
\hline RUR82 & 1 & -0.007145060 & 0.009232150 & -0.774 & 0.4390 \\
\hline NSMSABS & 1 & 0.001731569 & 0.008220815 & 0.211 & 0.8332 \\
\hline 585 & 1 & -0.02978878 & 0.02531812 & -1.177 & 0.2394 \\
\hline ASV 2585 & 1 & 0.006545683 & 0.01535318 & 0.426 & 0.5701 \\
\hline COMPS85 & 1 & 0.000739042 & 0.01057901 & 0.059 & 0.9448 \\
\hline voc585 & 1 & 0.006029545 & 0.01323630 & 0.456 & 0.6488 \\
\hline COMPAG85 & 1 & 0.002259627 & 0.001300553 & 1.737 & 0.0824 \\
\hline VDCTAG85 & 1 & -0.000799649 & 0.001552582 & -0.484 & 0.6285 \\
\hline ED85 & 1 & -0.009592551 & 0.004118775 & -2.329 & 0.0199 \\
\hline CED85 & 1 & -0.005880140 & 0.005765265 & -1.020 & 0.3078 \\
\hline EDX85 & 1 & 0.005383539 & 0.005422462 & 0.993 & 0.3209 \\
\hline RACE1 & 1 & 0.02112854 & 0.009911632 & 2.132 & 0.0331 \\
\hline RACE2 & 1 & -0.01062853 & 0.01724651 & -0.616 & 0.5378 \\
\hline AGE79 & 1 & 0.06179086 & 0.01403630 & 4.402 & 0.0001 \\
\hline AGES85 & 1 & -0.002583587 & 0.000818116 & -3.280 & 0.0010 \\
\hline AT85 & $i$ & 0.005556554 & 0.01573440 & 0.353 & 0.7240 \\
\hline ATT85 & 1 & 0.04642814 & 0.01969364 & 2.358 & 0.0185 \\
\hline EXPWKBS & 1 & -0.001525409 & 0.000141308 & -10.795 & 0.0001 \\
\hline EXPUS85 & $i$ & 0.004819165 & 0.000717755 & 0.714 & 0.0001 \\
\hline
\end{tabular}

isT :

NUMERATOR:

2.89391

DF: 1

F VALUE:

2.9169

DENOMINATOR:

0.99211 DF: 16583

$P R O B>F$ :

0.0877

ST:

NUMERATOR:

2. 59521

DF: $\quad 1$

F VALUE:

2.7166

DENOMINATOR:

0.99211 DF: 15583

PROB $>F$ :

0.0993 
FEMALE LOG VAGE RATE

MODELS WITH CROSS EQUATION CONSTRAINTS

NO WORK EXPER INTERACTIONS AND TECH VOC AND HS ACAD \& SCH ATT

NT GENERALIZED LEAST SRUARES

23:37 SUNDAY, JANUARY 8,1989

JEL: EI JGLS

, VARIABLE: LWG86

PARAMETER ESTIMATES

Table A 15: Used in Table 5

jT :

NUMERATOR: $\quad .0025289$ DF: 1 F VALUE: $\quad 0.0025$ DENOMINATOR: 0.995939 DF: 11364 PROB $>F: \quad 0.9598$ 
MODELS WITH CROSS EQUATION CONSTRAINTS

NO WORK EXPER INTERACTIONS AND TECH VOC AND HS ACAD \& SCH ATT CONSTRAINTS ON ALL TESTS

$20: 38$ SUNDAY, JANUARY 8,1989

NT GENERALIZED LEAST SQUARES

JGLS : E2
VARIABLE: LEARN85

PARAMETER ESTIMATES

Table A 16: Used in Table 5

\begin{tabular}{|c|c|c|c|c|c|}
\hline AARI ABLE & DF & ESTIMATE & ERROR & PARAMETER $=0$ & PROB $>I T:$ \\
\hline NTERCEP & 1 & 4.38664808 & 1.08061209 & 4.059 & 0.0001 \\
\hline $5 C 1$ & 1 & -0.02987648 & 0.02125954 & -1.405 & 0.1503 \\
\hline MATH & 1 & 0.07352108 & 0.01940237 & 3.789 & 0.0002 \\
\hline IVERBAL & 1 & 0.04373173 & 0.02274799 & 1.922 & 0.0547 \\
\hline $10 C T$ & 1 & -0.006792851 & 0.02815599 & -0.241 & 0.8094 \\
\hline ISV 2 AG85 & 1 & -0.004865432 & 0.008332802 & -0.584 & 0.5593 \\
\hline ISV2ED85 & 1 & 0.01437185 & 0.009044654 & 1.589 & 0.1122 \\
\hline WNL85 & 1 & -0.001725299 & 0.000503903 & -3.424 & 0.0006 \\
\hline PT 85 & 1 & 0.25781054 & 0.05295497 & 4.868 & 0.0001 \\
\hline 15685 & 1 & -0.03775495 & 0.05980631 & -0.531 & 0.5279 \\
\hline NE85 & 1 & 0.04582477 & 0.04535125 & 1.010 & 0.3124 \\
\hline 5085 & 1 & 0.04983460 & 0.04014084 & 1.241 & 0.2146 \\
\hline 1585 & 1 & -0.03254156 & 0.04511360 & -0.705 & 0.4805 \\
\hline HSP & 1 & 0.14442254 & 0.05193733 & 2.781 & 0.0055 \\
\hline TCLER & 1 & 0.02951816 & 0.01450278 & 2.035 & 0.0419 \\
\hline TCOMPU & 1 & 0.02600916 & 0.01832107 & 1.420 & 0.1559 \\
\hline CH 1LD85 & 1 & -0.18625205 & 0.03472632 & -5.363 & 0.0001 \\
\hline MAR85 & 1 & -0.04617236 & 0.03045047 & -1.515 & 0.1297 \\
\hline RURB2 & 1 & -0.07527531 & 0.04191723 & -1.795 & 0.0727 \\
\hline ISMSABS & 1 & -0.07327859 & 0.03331845 & -2.199 & 0.0280 \\
\hline SB5 & 1 & -0.33317831 & 0.08915218 & -3.737 & 0.0002 \\
\hline $15 V 2585$ & 1 & -0.23641100 & 0.05544050 & -4.189 & 0.0001 \\
\hline COMPS85 & 1 & 0.01455140 & 0.03503043 & 0.404 & 0.6864 \\
\hline $10 C 585$ & 1 & 0.04950414 & 0.05652531 & 0.875 & 0.3812 \\
\hline COMPAGB5 & 1 & 0.0097 .12222 & 0.005048121 & 1.924 & 0.0545 \\
\hline HOCTAG85 & 1 & 0.001151720 & 0.008505082 & 0.135 & 0.8923 \\
\hline ED85 & 1 & 0.07081495 & 0.03021784 & 2.343 & 0.0192 \\
\hline CED85 & 1 & -0.02339780 & 0.03369347 & -0.694 & 0.4875 \\
\hline DX85 & 1 & -0.007640555 & 0.02276923 & -0.336 & 0.7372 \\
\hline PACE 1 & 1 & 0.04847939 & 0.04402295 & 1.101 & 0.2709 \\
\hline RACE2 & 1 & -0.04286519 & 0.07631771 & -0.562 & 0.5744 \\
\hline HGE79 & 1 & 0.26810415 & 0.07311590 & 3.567 & 0.0003 \\
\hline MGES85 & 1 & -0.01469995 & 0.004115561 & -3.572 & 0.0004 \\
\hline $\operatorname{lT} 85$ & $i$ & -0.16104068 & 0.05923095 & -2.719 & 0.0056 \\
\hline ITT85 & $i$ & -0.06495052 & 0.08777860 & -0.958 & 0.3380 \\
\hline EXPWK85 & $i$ & -0.001537592 & 0.000816520 & -1.883 & 0.0598 \\
\hline XXPUS85 & $i$ & 0.01272012 & 0.003858916 & 3.288 & 0.0010 \\
\hline
\end{tabular}

NUMERATOR: $\quad 3.14293$ DF: 1 F VALUE: 3.1832

DENOMINATOR: 0.987359 DF: 11073 PROB $>F: \quad 0.0744$

NUMERATOR: 0.854378 DF: 1 F VALUE: 0.8653

DENOMINATOR: 0.987359 DF:11073 PROB >F: 0.3523 
FEMALE EARN INGS

MODELS WITH CROSS EQUATION CONSTRAINTS

NO WORK EXPER INTERACTIONS AND TECH VOC AND HS ACAD \& SCH ATT CONSTRAINTS ON ALL TESTS

$20: 49$ SUNDAY, JANUARY 8,1989

NT GENERALIZED LEAST SQUARES

JEL: E2

JGLS

, VARIABLE: EARN85

\begin{tabular}{|c|c|c|c|c|c|}
\hline & & & METER ESTIMAT & & \\
\hline & & Tabl & 17: Used in $\mathrm{T}$ & 5 & \\
\hline & & PARAMETER & STANDARD & T FOR HO: & \\
\hline ARIABLE & DF & EST IMATE & ERROR & PARAMETER=0 & $\mathrm{PROB}>\mathrm{IT}$ \\
\hline NTERCEP & 1 & -1.88252902 & 0.59575733 & -3.160 & 0.0016 \\
\hline SC I & 1 & -0.004888816 & 0.01139886 & -0.429 & 0.6580 \\
\hline MATH & 1 & 0.06534731 & 0.01122436 & 5.911 & 0.0001 \\
\hline VERBAL & 1 & 0.03528569 & 0.01186436 & 2.974 & 0.0030 \\
\hline $10 \mathrm{CT}$ & 1 & -0.01054046 & 0.01534949 & -0.687 & 0.4923 \\
\hline 1SV2AG85 & 1 & -0.009309643 & 0.004442047 & -2.096 & 0.0362 \\
\hline 15V2ED85 & 1 & 0.02713336 & 0.005287174 & 5.132 & 0.0001 \\
\hline JNL85 & 1 & -0.001351359 & 0.000296175 & -4.553 & 0.0001 \\
\hline :PT85 & 1 & 0.14468088 & 0.03607555 & 4.010 & 0.0001 \\
\hline 1SG85 & 1 & 0.03384152 & 0.03062880 & 1.105 & 0.2593 \\
\hline JE85 & 1 & 0.08423602 & 0.02822301 & 2.985 & 0.0029 \\
\hline 5085 & 1 & 0.07229597 & 0.02362034 & 3.061 & 0.0022 \\
\hline 1585 & 1 & 0.02055736 & 0.02801014 & 0.734 & 0.4530 \\
\hline $115 P$ & 1 & 0.07327317 & 0.03142453 & 2.332 & 0.0198 \\
\hline TCLER & 1 & 0.01830580 & 0.008023530 & 2.282 & 0.0226 \\
\hline ICOMPU & 1 & 0.04424786 & 0.009376567 & 4.719 & 0.0001 \\
\hline ZH1LD85 & 1 & -0.16220008 & 0.02132066 & -7.608 & 0.0001 \\
\hline 1AR85 & 1 & -0.02911251 & 0.01841903 & -1.581 & 0.1140 \\
\hline 3UR82 & 1 & -0.05522279 & 0.02549541 & -2.166 & 0.0304 \\
\hline JSMSA85 & 1 & -0.02183783 & 0.02025412 & -1.078 & 0.2812 \\
\hline$j 85$ & 1 & -0.14361700 & 0.05618210 & -2.556 & 0.0106 \\
\hline 1SV2585 & 1 & -0.22556050 & 0.02850452 & -7.885 & 0.0001 \\
\hline ;OMPS85 & 1 & -0.0 .1831126 & 0.01830115 & -1.001 & 0.3171 \\
\hline $10 \operatorname{cs} 85$ & 1 & 0.03470989 & 0.03078816 & 1.127 & 0.2596 \\
\hline ZOMPAG85 & 1 & 0.009495122 & 0.002621429 & 3.522 & 0.0003 \\
\hline IOCTAG85 & 1 & -0.000442058 & 0.004767095 & -0.093 & 0.9261 \\
\hline ED85 & 1 & 0.02609957 & 0.01085931 & 2.403 & 0.0163 \\
\hline ZED85 & 1 & 0.06515717 & 0.01408811 & 4.695 & 0.0001 \\
\hline$\equiv D \times 85$ & 1 & -0.02189070 & 0.01422687 & -1.539 & 0.1240 \\
\hline 3ACE 1 & 1 & 0.02757295 & 0.02574178 & 1.075 & 0.2824 \\
\hline ZACE2 & 1 & -0.03679598 & 0.04549805 & -0.809 & 0.4187 \\
\hline 1GE79 & 1 & 0.13985104 & 0.04141889 & 3.377 & 0.0007 \\
\hline 1GES85 & 1 & -0.009038051 & 0.002373045 & -3.809 & 0.0001 \\
\hline $1 T 85$ & 1 & -0.06464124 & 0.03738322 & -1.729 & 0.0839 \\
\hline ITRS & 1 & -0.13862443 & 0.04475204 & -3.098 & 0.0020 \\
\hline EXPWK85 & 1 & 0.000788402 & 0.000260786 & 3.023 & 0.0025 \\
\hline EXPWS85 & 1 & 0.005805119 & 0.001593955 & 3.642 & 0.0003 \\
\hline
\end{tabular}

jT :

NUMERATOR: $\quad 14.2151$ DF: 1 F VALUE: 14.4472 DENOMINATOR: 0.983935 DF:22533 PROB >F: 0.0001 
NO WORK EXPER INTERACTIONS AND TECH VOC AND HS ACAD \& SCH ATT

CONSTRAINTS ON ALL TESTS

i) $N$ TENERALIZED LEAST SQUARES

$22: 49$ SUNDAY, JANUARY 8,1989

DEL : E2 JGLS

PARIABLE: UNBS

PARAMETER ESTIMATES

\begin{tabular}{|c|c|c|c|c|c|}
\hline$V A R I A B L E$ & DF & $\begin{array}{l}\text { PARAMETER } \\
\text { ESTIMATE }\end{array}$ & $\begin{array}{r}\text { STANDARD } \\
\text { ERROR }\end{array}$ & $\begin{array}{c}\text { T FOR HO: } \\
\text { PARAMETER=0 }\end{array}$ & $P R O B>I T:$ \\
\hline INTERCEP & 1 & -0.003407073 & 0.21211970 & -0.015 & 0.9872 \\
\hline TSCI & 1 & -0.002058045 & 0.005116234 & -0.402 & 0.6875 \\
\hline TMATH & 1 & -0.01146352 & 0.004858118 & -2.360 & 0.0184 \\
\hline TVERBAL & 1 & -0.02198570 & 0.005408994 & -4.065 & 0.0001 \\
\hline VOCT & 1 & 0.005775485 & 0.007248321 & 0.797 & 0.4256 \\
\hline ASV2AG85 & 1 & 0.001802802 & 0.002085010 & 0.855 & 0.3873 \\
\hline ASV2ED85 & 1 & 0.005889582 & 0.002275167 & 3.027 & 0.0025 \\
\hline UNL85 & 1 & 0.000201571 & 0.000122948 & 1.639 & 0.1012 \\
\hline CPT85 & 1 & -0.02440149 & 0.01444249 & -1.690 & 0.0912 \\
\hline HSG85 & 1 & 0.005667349 & 0.01320351 & 0.429 & 0.6678 \\
\hline NE85 & 1 & -0.03772330 & 0.01067481 & -3.534 & 0.0004 \\
\hline 5085 & 1 & -0.03264712 & 0.009318852 & -3.503 & 0.0005 \\
\hline 1SB85 & 1 & -0.02288823 & 0.01093869 & -2.092 & 0.0355 \\
\hline HISP & 1 & 0.01024087 & 0.01260543 & 0.812 & 0.4156 \\
\hline TCLER & 1 & -0.01066781 & 0.003491689 & -3.055 & 0.0023 \\
\hline TCOMPU & 1 & -0.009338681 & 0.004493251 & -2.078 & 0.0378 \\
\hline CHILDB5 & 1 & 0.001910961 & 0.008568179 & 0.223 & 0.8235 \\
\hline MAR85 & 1 & -0.005289697 & 0.007875679 & -0.572 & 0.5019 \\
\hline RUR82 & 1 & 0.01256503 & 0.009773890 & 1.286 & 0.1987 \\
\hline NSMSABS & 1 & -0.002865998 & 0.008176221 & -0.351 & 0.7260 \\
\hline 585 & 1 & -0.007340938 & 0.02380055 & -0.308 & 0.7578 \\
\hline ASV2S85 & 1 & -0.009536924 & 0.01544158 & -0.618 & 0.5359 \\
\hline COMPS85 & 1 & 0.003650525 & 0.009881245 & 0.369 & 0.7118 \\
\hline VOCSBS & 1 & 0.03239495 & 0.01505047 & 2.017 & 0.0438 \\
\hline COMPAG85 & 1 & 0.004592860 & 0.001256208 & 3.656 & 0.0003 \\
\hline VOCTAGBS & 1 & 0.000315291 & 0.002199369 & 0.143 & 0.8860 \\
\hline ED85 & 1 & -0.01728128 & 0.005847238 & -2.955 & 0.0031 \\
\hline CED85 & 1 & 0.003614726 & 0.006847483 & 0.528 & 0.5976 \\
\hline EDX85 & 1 & 0.005140101 & 0.005528591 & 0.930 & 0.3526 \\
\hline $\mathrm{RACE} I$ & 1 & 0.03671252 & 0.01012605 & 3.626 & 0.0003 \\
\hline RACE2 & 1 & 0.02706217 & 0.01790564 & 1.511 & 0.1308 \\
\hline AGE79 & 1 & 0.03842048 & 0.01458010 & 2.635 & 0.0085 \\
\hline AGES85 & 1 & -0.001656688 & 0.000839744 & -1.973 & 0.0486 \\
\hline ATB5 & 1 & 0.01270951 & 0.01496586 & 0.849 & 0.3958 \\
\hline ATT85 & 1 & 0.03062330 & 0.01828074 & 1.575 & 0.0940 \\
\hline EXPWKB5 & 1 & -0.001259603 & 0.000149477 & -8.427 & 0.0001 \\
\hline EXPVS85 & 1 & 0.004230472 & 0.000769393 & 5.498 & 0.0001 \\
\hline
\end{tabular}

ST:

NUMERATOR: 9.48355 DF: 1 F VALUE: 9.5341 DENOMINATOR: 0.994694 DF: 14208 PROB >F : 0.0020

ST:

NUMERATOR: 1.83459 DF: 1 F VALUE: 1.8444 DENOMINATOR: 0.994594 DF: 14208 PROB $>F: \quad 0.1745$ 
APPENDIX B

\section{The ASVAB}




\section{COUNSELOR'S MANUAL FOR THE}

ARMED SERVICES VOCATIONAL APTITUDE BATTERY FORM 14

JULY 1984 


\section{Purposes}

The ASVAB is a multiple aptitude battery designed for use with students in Grades 11 and 12 and in postsecondary schools. The test was developed to yield results that are useful to both schools and the military. Schools use ASVAB test results to provide educational and career counseling for students. The military services use the results to identify students who potentially qualify for entry into the military and for assignment to military occupational training programs.

Like other multiple aptitude batteries, the ASVAB measures developed abilities and predicts what a person could accomplish with training or further education. This test is designed especially to measure potential for occupations that require formal courses of instruction or on-the-job training. In addition, it provides measures of general learning ability that are useful for predicting performance in academic areas.

The ASVAB can be used for both military and civilian career counseling. Scores from this test are valid predictors of success in training programs for enlisted military occupations. Through the use of validity generalization techniques, predictions from military validity studies can be generalized to occupations that span most of the civilian occupational spectrum. Although some enlisted occupations are military specific, more than $80 \%$ of these occupations have direct civilian occupational counterparts.

Since the ASVAB was first used in high schools in 1968, it has been the subject of extensive research and has been updated periodically. Appendix $A$ contains a brief history of the ASVAB and the various forms that have been used.

\section{Key Features}

ASVAB-14, introduced in the 1984-85 school year, contains several key features that were not included in previous forms. These key features include

- improved usefulness in measuring vocational aptitudes: In addition to yielding academic composites that provide measures of academic potential, ASVAB-14 supplies occupational composites that provide measures of potential for successful performance in four general career areas.

- increased reliability: Changes in the length and number of subtests have increased the test's reliability without a substantial increase in testing time.

- nationally representative norms: ASVAB-14 is normed on a nationally representative sample of 12,000 women and men, ages 16-23, who took the test in 1980.

\section{Content}

\section{Subtests}

The ASVAB consists of 10 subtests. Eight are power subtests that allow maximum performance with generous time limits. Two subtests are speeded. 
Figure $1-1$ presents the subtests, the time allowed for the administration of each subtest, the number of items per subtest, and the descriptions of the abilities or knowledge measured. The subtests are designed to measure general cognitive abilities and acquired information in specific areas. Sample questions for each subtest are provided in Appendix B.

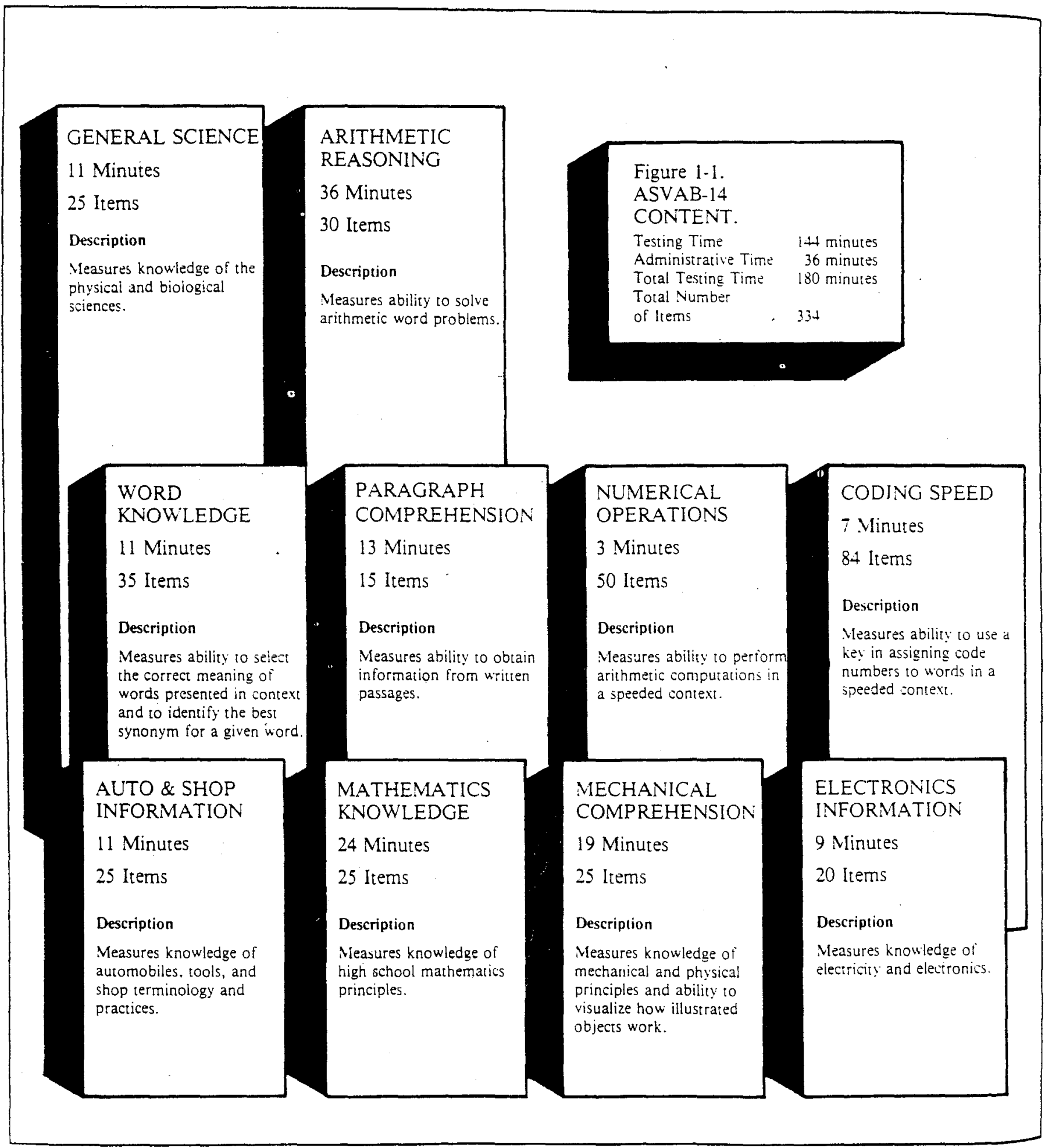




\section{A. History of the ASVAB}

Forerunners of the ASVAB date back to World War II. During World War ll. each military service employed its own tests 10 screen recruits for eligibility and 10 classify and assign enlisted personnel. These tests included general measures of intellectual ability and specific aptitude measures that reflected the needs of each service.

The need for a common test for all the military began with the passage of the Selective Service Act in 1948. which mandated the development of a standard screening test for enlistment qualification. The Army General Classification Test. then the most widely used of the military instruments. was selected as the model for the new joint-service test. The new test. called the Armed Forces Qualification Test (AFQT), became operational in 1950.

Each service continued to administer a battery of aptitude tests for the initial assignment of recruits to technical schools or on-the-job training. These aptitude instruments were continuously evaluated and revised as training procedures and equipment changed.

The Air Force was the first service to test students within the high schools with the introduction of the Airman Qualifing Examination (AQE) in 1958. The AQE. an abbreviated version of the test then used by the Air Force to classify enlisted personnel. was designed to help recruiting efforts and 10 aid students in career exploration and decision making. The $A Q E$ was administered at no cost to students or schools. Shortly after the Air Force began using the AQE. the Army and Vay produced brief versions of their classification batteries that were used in high schools.

To prevent costly duplication of effort by the military and the schools, and to encourage equitable selection standards across the services, the Department of Defense. in 1966. directed all services to explore the development of a single. multipurpose military test battery for use in high schools. Objectives for this testing program included the following:

- Names and test scores of all $1 /$ th and 12 th graders who were tested would be provided to military recruiters.

- An AFQT score could be derived from test scores to determine eligibility for entrance into the military.

- Test results would provide aptitude composite scores associated with success in military training programs for jobs in all services.

- Students would receive academic ability and vocational aptitude scores to assist them in career exploration and decision making

- Schools would receive a multiple aptitude battery and supporting materials at no cost to schools or students.

- Students' interest in military careers would be stimulated through the test and associated materials. 
The Armed Services Iocational Aptitude Batrer. (ASVAB) was designed to accomplish these objectives. ASVAB testing. as a joint military effort. began in 1968. Since that time. ASVAB testing has been well received by high schools throughout the United States. Presently, the ASVAB is given in about 14.000 schools. Approximately I million students take the ASVAB each year.

Various forms of the ASVAB have been produced. Some forms of the ASVAB have been used exclusively in schools. Other forms have been used for military qualification. placement. and research. The different forms that have been developed are identified in Table A-1.

\section{Table A-1}

\section{ASVAB Forms by Dates Used}

\begin{tabular}{lcc} 
Years in Use & School Use & Military Use \\
\hline $\begin{array}{l}1968-73 \\
1973-76\end{array}$ & 1 & None \\
& 2 & $3+1$ \\
$1976-84$ & (4 was never used) & \\
$1980-84$ & 5 & $6.7($ Until 1980) \\
$1984-$ present & & $8.9 .10+t$ \\
\hline
\end{tabular}

I The Air Force and Marine Corps were the only services to use Form 3 . The Marine Corps used it only in 1975.

TTASVAB-14 is parallel to Forms 8. 9. and 10 as well as to Forms 11. 12. and 13. 


\section{B. Sample Test ltems}

\section{General Science}

1. An eclipse of the sun throws the shadow of the

1-A moon on the sun.

1-B moon on the earth.

1-C earth on the sun.

1-D earth on the moon.
2. Substances which hasten chemical reaction time without themselves undergoing change are called
2-A buffers.
2-B colloids
2-C reducers.
2-D catalysts.

\section{Arithmetic Reasoning}

3. How many 36-passenger busses will it take to carry 144 people?
3-A 3
3-B 4
$3-\mathrm{C} \quad 5$
3-D 6

4. It costs $\$ 0.50$ per square yard to waterproof canvas. What will it cost to waterproof a canvas truck cover that is $15^{\prime} \times 24^{\prime}$ ?
4-A $\$ \quad \$ 6.67$
4-B $\$ 18.00$
4-C $\$ 20.00$
4-D $\$ 180.00$

\section{Word Knowledge}

5. The wind is variable today.

5-A mild

- 5-B steady

5-C shifting

5-D chilling
6. Rudiments most nearly means
6-A politics.
6-B minute details.
6-C promotion opportunities.
6-D basic methods and proce- dures. 


\section{Paragraph Comprehension}

7. Twenty-five percent of all household burglaries can be attributed to unlocked windows or doors. Crime is the result of opportunity plus desire. To prevent crime, it is each individual's responsibility to

i 7-A provide the desire.

7-B provide the opporiunity.

7-C prevent the desire.

7-D prevent the opportunity.
8. In certain areas water is so scarce that every attempt is made to conserve it. For instance, on one oasis in the Sahara Desent the amount of water necessary for each date palm tree has been carefully determined.

How much water is each tree given?

8-A no water at all

8-B water on alternate days

8-C exactly the amount required

8-D water only if it is healthy

\begin{tabular}{|c|c|c|c|c|c|}
\hline \multicolumn{6}{|c|}{ Numerical Operations } \\
\hline \multirow[t]{5}{*}{9.} & $3+9=$ & & 10. & $60 \div 15$ & $15=$ \\
\hline & 9-A & 3 & & $10-A$ & 3 \\
\hline & $9-B$ & 6 & & $10-B$ & 4 \\
\hline & $9-C$ & 12 & & $10-C$ & 5 \\
\hline & 9-D & 13 & & $10-D$ & 6 \\
\hline
\end{tabular}

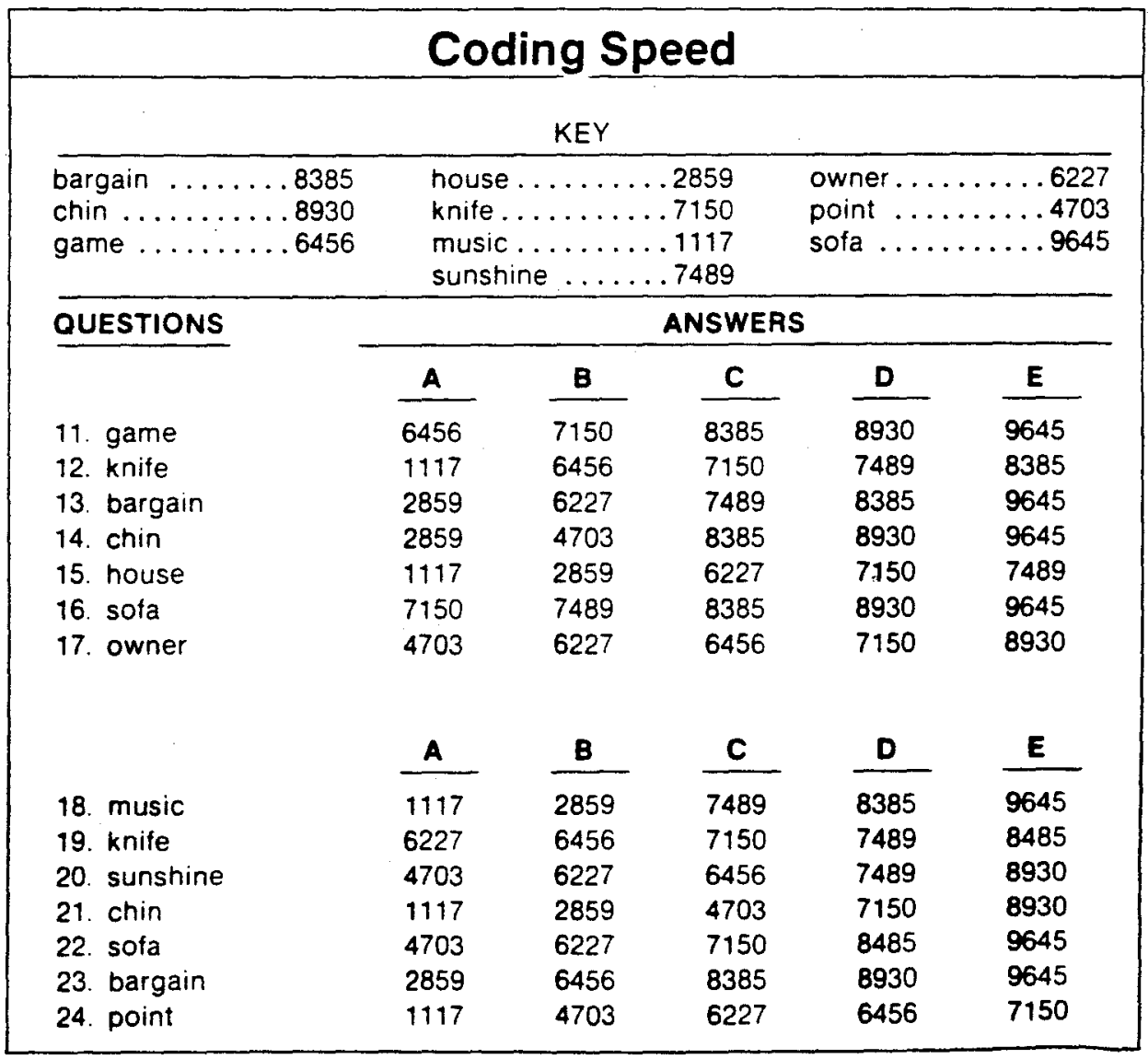




\section{Auto \& Shop Information}

25. A car uses too much oil when which parts are worn?

25-A pistons

25-B piston rings

25-C main bearings

25-D connecting rods

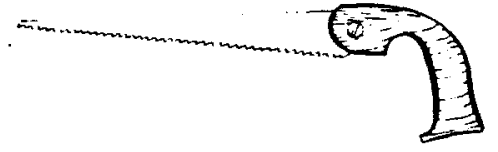

26. The saw shown above is used mainly to cut

26-A plywood.

26-B odd-shaped holes in wood.

26-C along the grain of the wood.

26-D across the grain of the wood.

\section{Mathematics Knowledge}

27. If $x+6=7$, then $x$ is equal to

27-A 0

27-B 1

$27-C \quad-1$

27-D $\quad 7 / 6$

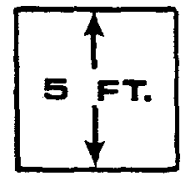

28. What is the area of this square?

28-A 1 square foot

28-B 5 square feet

28-C 10 square feet

28-D 25 square feet 


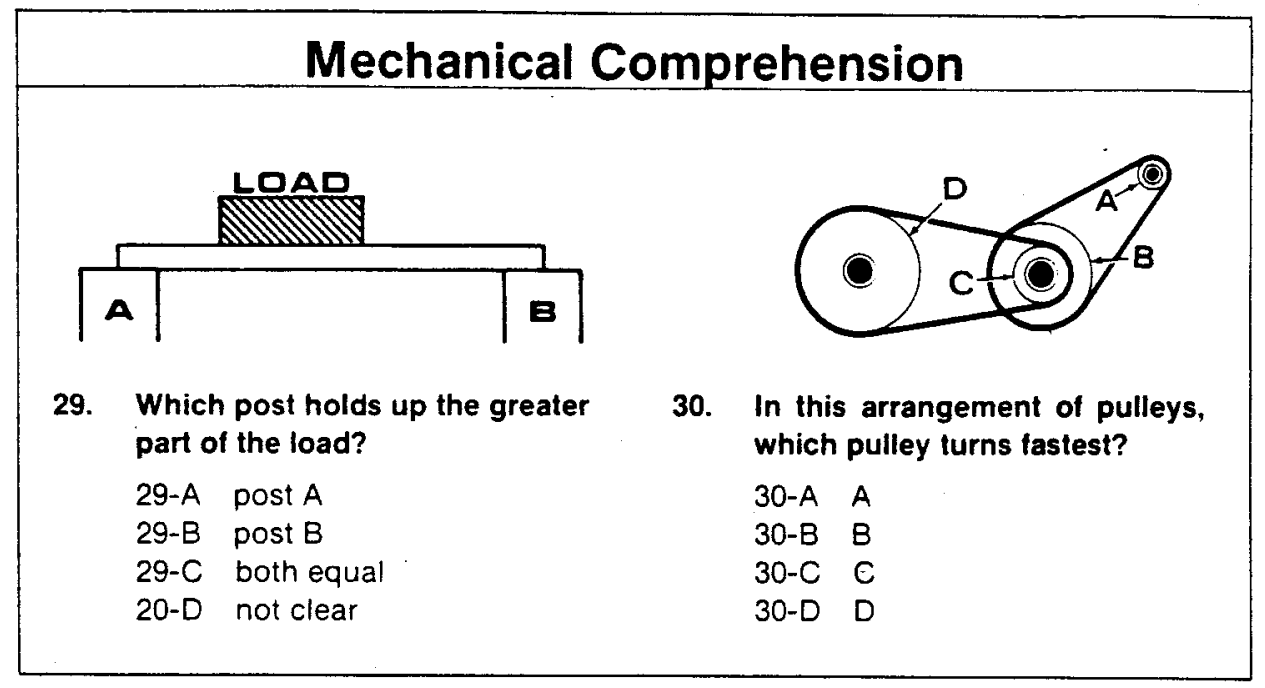

\section{Electronics Information}

31. Which of the following has the least resistance?

31-A wood

31-B iron

31-C rubber

31-D silver

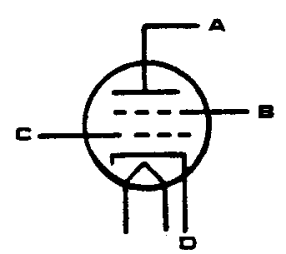

32. In the schematic vacuum tube illustrated, the cathode is element

32-A A

$32-\mathrm{B} \quad \mathrm{B}$

$32-\mathrm{C} \quad \mathrm{C}$

32-D D

\section{Key To The Sample Test Items}

$\begin{array}{rlll}1 . & \mathrm{B} & 17 . & \mathrm{B} \\ 2 . & \mathrm{D} & 18 . & \mathrm{A} \\ 3 . & \mathrm{B} & 19 . & \mathrm{C} \\ 4 . & \mathrm{C} & 20 . & \mathrm{D} \\ 5 . & \mathrm{C} & 21 . & \mathrm{E} \\ 6 . & \mathrm{D} & 22 . & \mathrm{E} \\ 7 . & \mathrm{D} & 23 . & \mathrm{C} \\ 8 . & \mathrm{C} & 24 . & \mathrm{B} \\ 9 . & \mathrm{C} & 25 . & \mathrm{B} \\ 10 . & \mathrm{B} & 26 . & \mathrm{B} \\ 11 . & \mathrm{A} & 27 . & \mathrm{B} \\ 12 . & \mathrm{C} & 28 . & \mathrm{D} \\ 13 . & \mathrm{D} & 29 . & \mathrm{A} \\ 14 . & \mathrm{D} & 30 . & \mathrm{A} \\ 15 . & \mathrm{B} & 31 . & \mathrm{D} \\ 16 . & \mathrm{E} & 32 . & \mathrm{D}\end{array}$

